\title{
O DESIGN DE INTERFACES PARA TV INTERATIVA
}

Dissertação de Mestrado apresentada à Escola de Comunicações e Artes da Universidade de São Paulo como exigência parcial para obtenção do Título de Mestre em Artes Visuais.

Área de Concentração: Poéticas Visuais

Andrea Brazil Mugnaini

Orientadora: Profa. Dra. Monica Tavares 
BANCA EXAMINADORA. 
À professora Monica Tavares, pela orientação e amizade.

Aos colegas Cézar Hirashima e Gil Barros, pelas conversas e palavras de incentivo que tanto ajudaram na confecção deste trabalho.

À amiga Gabriela Santos que sempre incentivou e acreditou nesta pesquisa.

Ao meu marido Sérgio, pela paciência e incentivo.

À minha mãe Tania Kobler Brazil e às minhas irmãs Bárbara, Mariana e Carolina, pelo apoio e inspiração. 
Lista de figuras --.-- 08

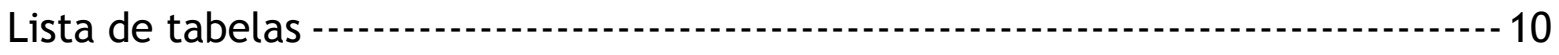

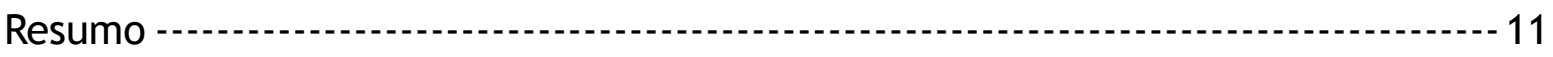

Abstract - -

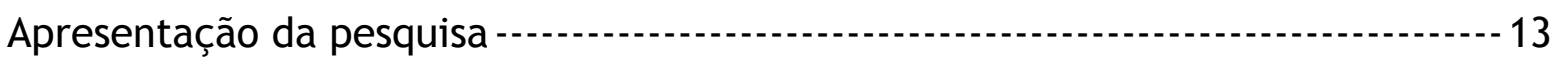

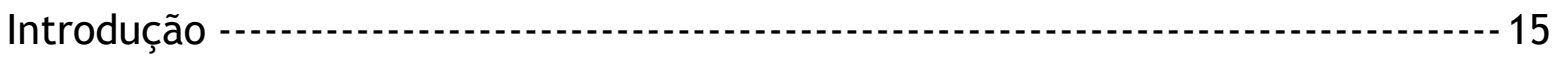

CAPÍTULO I

1. TEORIAS E CONCEITOS: DESIGN, ARTE, COMUNICAÇÃO E TELEVISÃO

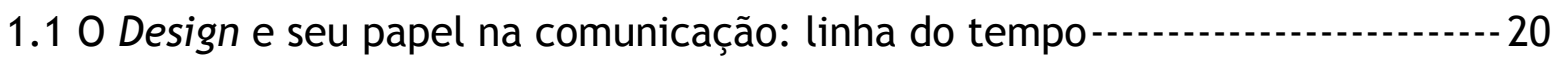

1.2 Informação, mensagem e processo comunicacional. Design comunica--------- 58

CAPÍTULO II

2. INTERFACE DE TVI: PROJETO, DESIGN E DESENHO

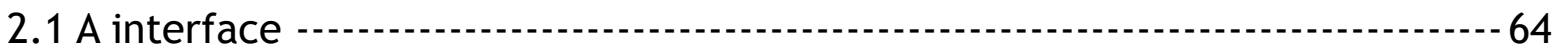

2.20 método heurístico do projeto -

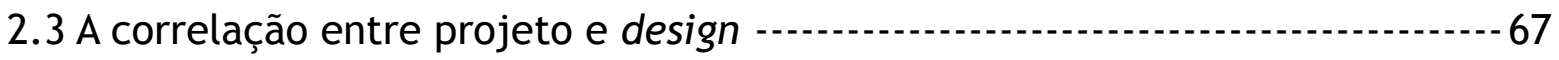

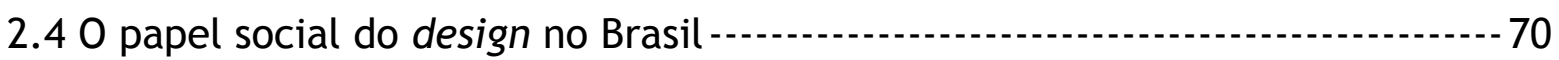

CAPÍTULO III

3. TVI: CONVERGÊNCIA DE MÍDIAS

3.1 Estudo de casos - 73

3.2 Apresentação dos casos selecionados -......- 74

3.2.1 Reação ou interação? --...-.-.- 80

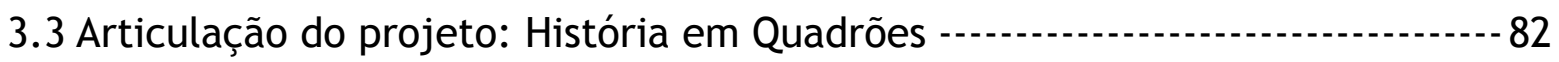

CAPÍTULO IV

4. METODOLOGIA PARA CRIAÇÃO DE INTERFACES DE TVI-.......-. 89

Considerações finais -

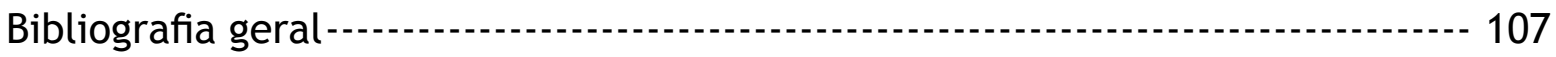


Fig 01. Cadeira da linha Sussex fabricada pela Morris \& Co. a partir de 1860 ---- 22

Fig 02. Constantin PERSKYI, "Télévision au moyen de l'électricité"--.--.-- 26

Fig 03. Cadeira Vermelha e Azul de Gerrit Rietveld-1..- 27

Fig 04. A Televisão mecânica inglesa de 1926 - 28

Fig 05. Aparelho receptor - 28

Fig 06. Livro que expôs os objetivos e realizações da Bauhaus -

Fig 07. Novo edifício da Bauhaus em Dessau --...-...- 30

Fig 08. Cadeira Barcelona - 31

Fig 09. Mapa do metrô de Londres, 1933

Fig 10. Geladeira Coldspot - 33

Fig 11. Bush TV12 34

Fig 12. O Winky Dinky Magic Kit (2007) - 37

Fig 13. Programa Winky Dinky and You (1953) - 38

Fig 14. Programa Winky Dinky and You (1953) -

Fig 15. A cadeira Antílope de Ernest Race - 38

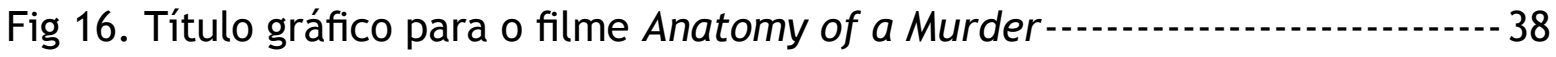

Fig 17. Sony TV8-301 39

Fig 18. Obra de Richard Hamilton sobre consumismo-- 40

Fig 19. Poltona Mole, Sergio Rodrigues -- 40

Fig 20. JVC Videosphere - 41

Fig 21. Logo da CBS-1 41

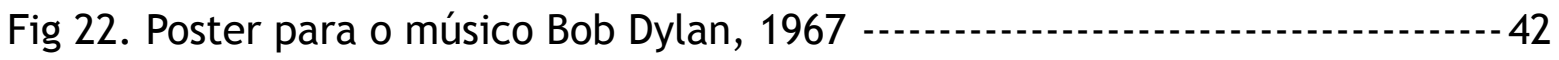

Fig 23. Página do CEEFAX de janeiro de 1975 - 43

Fig 24. Televisão Black 12 - 44

Fig 25. Logo da MTV - 45

Fig 26. Faqueiro DRY - 47

Fig 27. Chaleira - 48

Fig 28. Identidade gráfica do Lloyd's of London - 49

Fig 29. Apple Macintosh, 1984

Fig 30. Cortador de queijo - 50

Fig 31. Poltrona Big Easy - 51

Fig 32. Revista Colors - 52

Fig 33. TV Sony KV-32 FD 1, 1998

Fig 34. TV Jim Nature (1994) - 53

Fig 35. TiVO- 54

Fig 36. iMac 54

Fig 37. iPod (2001) 56

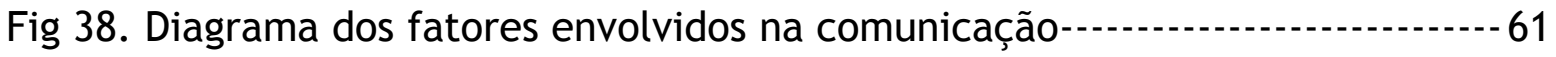


Fig 39. Interface de TVI da Bloomberg - 72

Fig 40. Website da Bloomberg - 72

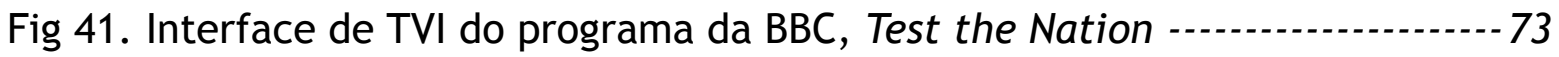

Fig 42. Website da BBC, área do programa Test the Nation - 73

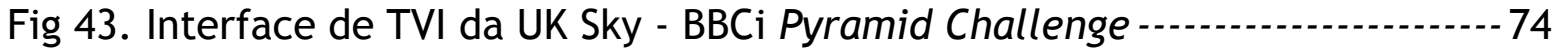

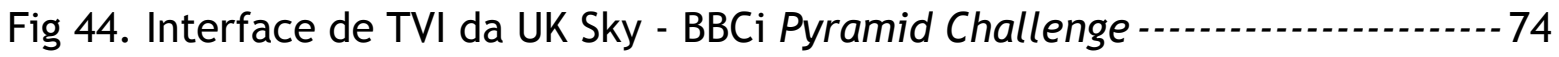

Fig 45. Interface de TVI da UK Sky - BBCi Pyramid Challenge -......- 74

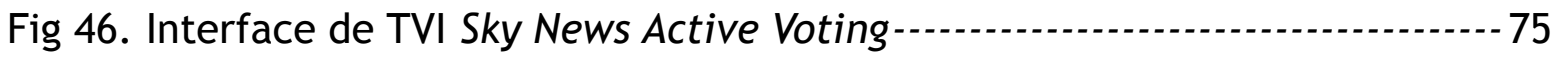

Fig 47. Interface de TVI Sky News Active Voting-1..- 75

Fig 48. Interface de TVI da Living TV Active - 76

Fig 49. Interface de TVI da Living TV Active - 76

Fig 50. Interface de TVI da Living TV Active - 76

Fig 51. Interface de TVI da Living TV Active -...- 76

Fig 52. Interface de TVI da EMA Voting Application on CSD Spain -...-...-..-.-. 77

Fig 53. Interface de TVI da EMA Voting Application on CSD Spain -...-..-..- 77

Fig 54. Interface de TVI da EMA Voting Application on CSD Spain -..............- 77

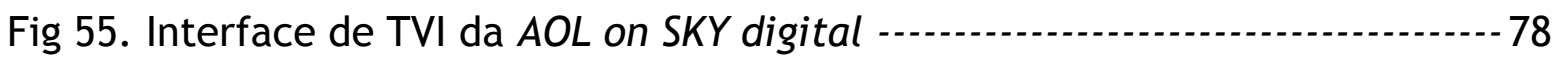

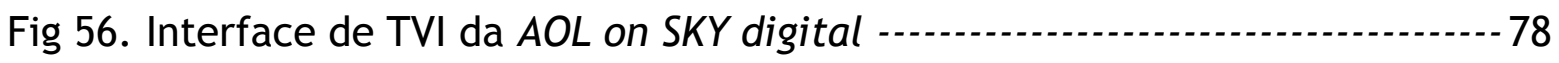

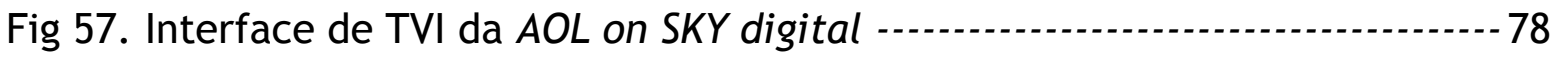

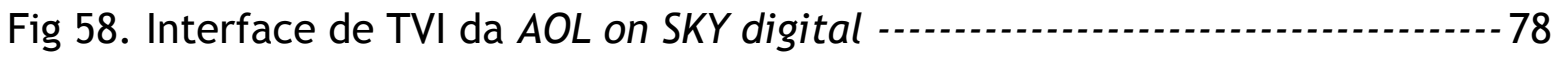

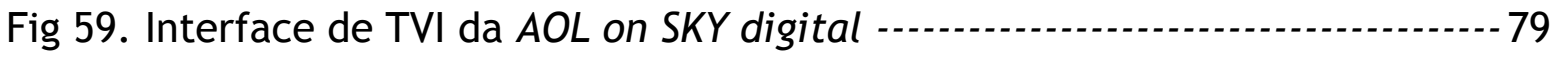

Fig 60. Interface de TVI da BBC CBeebies on Sky Digital - 79

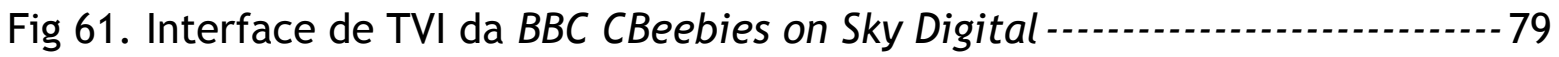

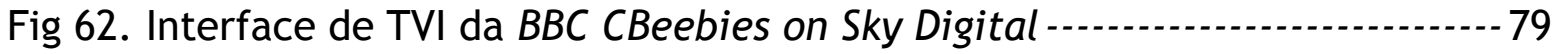

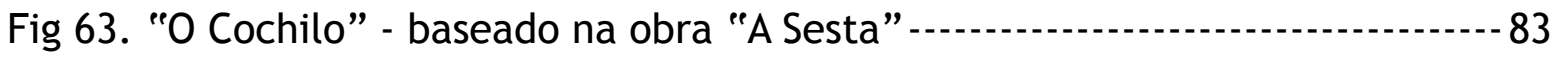

Fig 64. "A Sesta" (1890) - Van Gogh - 83

Fig 65. Esquema de convergência - 85

Fig.66. Esquema de convergência--..-. 86

Fig.67. Diagrama que sugere a estratégia do projeto-- 87

Fig.68. Diagrama que sugere o mapa de informações -

Fig.69. Diagrama que sugere o esqueleto de navegação total do projeto-------- 89 
LISTA DE TABELAS.

Tabela 01. As possibilidades estruturais da interatividade 
Esta dissertação está disposta em quatro capítulos.

No primeiro capítulo, a pesquisa será situada no momento histórico em que se insere. Traçaremos, de maneira concisa e pontual, uma linha do tempo correspondente a um breve sumário do histórico da atividade do design e da televisão para que possamos estabelecer conceitos sobre essa atividade, além de identificar algumas das suas mais relevantes manifestações e a atuação de seus profissionais. Investigaremos sobre: a) O design e seu papel na comunicação e b) a informação, a mensagem e o processo de comunicação. 0 que proporemos neste capítulo, é esclarecer o modo como o receptor é cativado, não esquecendo a idéia de que o design deve comunicar com vistas a sanar as necessidades humanas.

No segundo capítulo, estudaremos o método heurístico do projeto, quando então serão relacionados projeto e design como atividades constitutivas dos processos de desenvolvimento de interfaces de TV Interativa (TVI). Ao final deste capítulo traremos à tona a problemática do papel social do design no Brasil.

O terceiro capítulo abrangerá, principalmente, a apresentação de algumas interfaces de TVI. A partir dos duzentos e trinta e cinco (235) casos identificados, foram selecionados seis (6), considerando os tipos de interatividade observados e também os modos de configuração de cada um deles.

No quarto capítulo apresentaremos como projeto prático o protótipo experimental sugerido, bem como o seu desenvolvimento em telas de interfaces gráficas . A meta será evidenciar uma metodologia para o desenvolvimento do design de interfaces de TVI. 
The present dissertation is composed of four chapters.

In the first chapter, the research will be placed in the historical moment it belongs to. We shall concisely present a time line that corresponds to a brief summary of the design and TV activities in order to establish concepts regarding them and identify both their most relevant manifestations and how their professionals work. We shall investigate: a) The design and its role in communication and b) the communication's information, message and process. In this chapter we shall clarify how the receiver is captivated, without losing sight that the design's communication should aim at serving human needs.

In the second chapter, we shall study the project's heuristic method, where project and design will be presented as activities that are part of the development processes of Interactive TV interfaces (ITV). At the end of the chapter we shall discuss the social role design plays in Brazil.

The third chapter will mainly present a few ITV interfaces. From the three hundred and thirty five (235) identified cases, six (6) were selected taking into consideration the type of interactivity observed as well as their configuration modes.

At last, in the fourth chapter we shall present as the practical project the experimental prototype suggested and its development in graphic interface screens. We shall try to propose a methodology for the design development in ITV interfaces. 


\section{O Problema}

Trata-se de uma investigação sobre a atuação do designer na construção do processo criativo para a TVI.

$\mathrm{Na}$ delimitação do problema foi considerado que o desenvolvimento de um projeto que vise produzir uma interface de TVI é tarefa do designer e que, para realizá-la, ele deve contar, necessariamente, tanto com o próprio repertório, quanto com o do espectador de TV. 0 trabalho do profissional de design envolve processos criativos que circunscrevem o modo como ele seleciona, combina, ordena e apresenta os elementos do seu repertório. Estes elementos, somados às informações inerentes ao projeto, formam as mensagens que compõem a interface de TVI, que serão posteriormente analisados no decorrer desse trabalho.

O problema da pesquisa está, portanto, em identificar como o designer desenvolve o processo que transforma um determinado tipo de informação em possibilidades de ações efetivas ${ }^{1}$ a serem realizadas pelo espectador. Melhor dizendo, a maneira como um determinado tipo de informação se transforma em uma interface de TVI eficiente na satisfação das reais necessidades do espectador de TV. Acredita-se que a experiência do espectador perante a interface só deverá ter sucesso ao revelar condições para que ele, além de perceber e receber as mensagens ali apresentadas de forma ordenada, possa também processá-las em ação efetiva. 
"O design é a atividade que gera planos, projetos e produtos. É uma atividade que produz resultados tangíveis, os quais podem funcionar como demonstrações ou como discussões das maneiras em que poderíamos viver. O design está reinventando constantemente os seus objetos de estudo, sua área de abrangência; não se limita, portanto, a categorias antiquadas de produtos. 0 mundo espera novidades por parte dos designers. Esta é a natureza do design (MARGOLIN, 1996, p.47)".

O tema desta dissertação é o design de interfaces para TV Interativa (TVI) e se desenvolve dentro do contexto das Novas Tecnologias da Comunicação (NTC), enfocando a atividade de design como produtora de artefatos que apresentam idéias através de sua forma, função e usos. Mais do que uma dissertação sobre esse tema, trata-se de uma investigação que pretende refletir sobre o sistema de produção de artefatos dentro do contexto das NTC. Pretende-se, também, demonstrar neste trabalho como o designer desenvolve e percorre processos criativos que o levam ao projeto e, conseqüentemente, às definiçõos da forma, aparência e possibilidades de usos das interfaces de TVI.

A nossa meta é tentar criar um espaço crítico dentro deste sistema e este se justifica ao admitirse que este espaço somente poderá ser criado dentro de uma universidade pública e em um ambiente de pesquisa. Por um lado, o profissional de design de mercado exibe a experiência prática de quem trabalha para o sistema, onde dificilmente encontra espaço para reflexão. Por outro, o profissional acadêmico tem como atividade principal a reflexão. Consideramos que existe uma distância entre a prática e a teoria, ou seja, hoje muitos artefatos são produzidos e pouco sobre isto é pensado de maneira crítica e construtiva para a sociedade. Do mesmo modo, algumas teorias partem do pressuposto que, dentro do contexto das NTC, o fenômeno do surgimento da inovação se faz a partir da atividade de reflexão somada à atividade projetual e à competência em desenho do designer. Em outras palavras, é da retroalimentação entre teoria e prática que formar-se-ão profissionais de design cada vez mais munidos de consciência crítica.

Considerando que hoje a produção de conhecimento sobre o design de interfaces de TVI é uma área ainda em desenvolvimento no Brasil e que a TVI é uma tecnologia não completamente instalada no país, podemos afirmar que a realização deste trabalho é, no mínimo, inovadora. 


\section{TEORIAS E CONCEITOS: DESIGN, ARTE, COMUNICAÇÃO E TELEVISÃO}

O conceito de design sofreu grandes e constantes mudanças ao longo do tempo. Durante a década passada, principalmente, passou por uma vasta difusão e popularização. Geralmente limitado aos produtos de casa, o design ganhou, equivocadamente, uma conotação pública de atividade de decoração que o associa à condição de algo caro, complicado e de curta duração, com promessa de glamour instantâneo (BONSIEPE; 1997; p.10-17). Por conseguinte, buscaremos esclarecer as mudanças de conceito de design ocorridas através das décadas passadas, ressaltando alguns marcos históricos e, com isso, também as mudanças do discurso projetual. Para tanto, traçaremos uma linha do tempo correspondente ao sumário do histórico da atividade de design e sua relação com a comunicaçãa² e a televisão no contexto das NTC. Assim, poderemos estabelecer alguns conceitos sobre essa atividade, além de identificar suas mais relevantes manifestações e atuações profissionais. É importante ressaltar que não pretendemos nos aprofundar na história do design, limitando-se apenas a expor um breve sumário que localizará o nosso trabalho em seu devido cenário histórico e cultural.

Iniciamos o sumário a seguir pouco após o ano de 1800, quando a indústria e com ela o design começam a aparecer no mundo, principalmente na Inglaterra. O designer era ainda um artesão que se movimentou no sentido de trabalhar juntamente com a indústria em prol de produtos de boa qualidade e bom gosto. Entre as décadas de 1920 e 1940 as transformações sofridas pela indústria exigiram uma intensificação do trabalho de design. Surgiram, nesse período, novas tecnologias - dentre elas oficialmente a televisão, novos materiais e os meios de transporte foram popularizados. Somente durante esta época é que a figura do designer gráfico se desenvolveu com a característica de um especialista em resolver problemas técnicos ao criar elementos estruturais de comportamento visual.

Em seguida, na década de 30, foram fabricados os primeiros aviões de passageiros e a consequente admiração pela velocidade como elemento estético deu origem a um modismo inspirado em formas aerodinâmicas, que foram aplicadas em muitos objetos industrializados da época. A partir de 1945, com o término da Segunda Grande Guerra, surgiu uma enorme demanda de produção industrial, pois 
os países envolvidos na guerra estavam em processo de reconstrução. Para suprir essa demanda, o produto era concebido pela indústria como um projeto dos campos da engenharia e pela produção em série, que lançava produtos padronizados no mercado a um preço acessível. No começo dos anos 50 já não havia concorrência entre as indústrias e seus esforços eram voltados para essa produção padronizada. A forma dos produtos era concebida no que dizia respeito às exigências da simplicidade construtiva e funcional ${ }^{3}$. Os países que haviam participado da guerra enviaram uma grande quantidade de soldados para as frentes de batalha e fabricavam, de forma acelerada, uma grande quantidade de materiais bélicos, fatores que garantiram sua economia interna e relações externas. Com o fim da Guerra houve a necessidade de desacelerar a produção, fechar fábricas bélicas e empregar os trabalhadores, agora ociosos, bem como os soldados que retornavam à pátria. Assim, os recursos produtivos, como fábricas de materiais bélicos, foram ajustados e se transformaram em fábricas de automóveis, aviões, etc (CARDOSO, 2004, p.130-132, 144-150).

Em países como os Estados Unidos, que sairam vitoriosos da Guerra, a partir de 1955 a abundância e o desperdício se tornaram presentes, quando o consumo era a força motriz da economia. Para Bonsiepe, o design aparece nesse contexto de pós-guerra como nada mais do que cosmética (BONSIEPE, 1997, p.11). Também para o designer Victor Papanek, "Since World War II, our major commitment has been to stylistic and artificial obsolonce. (Ironically enough, the accelerated pace of technological innovation frequently makes a product obsolete before artificial or stylistic obsolensce can be tacked on to it.) (PAPANEK, 2004, p.34)". ${ }^{4}$ Apesar de limitar a atuação do designer neste cenário, a visão do design como cosmética serviu para acelerar a indústria no que diz respeito às inovações tecnológicas. 0 fato é que, desde muito cedo na história da sociedade humana, o produto se tornava algo obsoleto em pouco tempo, em primeira instância devido às inovações tecnológicas e não pelo seu styling ${ }^{5}$ (CARDOSO, 2004, p.134).

Na década de setenta houve muitos testes direcionados à TV Interativa. Nos Estados Unidos, a

3 Obviamente, ressalta-se novamente, que, após a Guerra, a sociedade encontrava-se em um momento de reconstrução, onde os desperdícios de materiais eram inconcebíveis. Portanto, os esforços produtivos eram contrários aos desperdícios obedecendo a uma política de produção que objetivava poucos modelos de grande durabilidade.

4 Tradução da autora para a língua portuguesa: "Desde a Segunda Guerra Mundial, o nosso principal comprometimento tem sido com a cosmética e com a obsolência artificial. (ironicamente, o rítmo acelerado das inovações tecnológicas sempre fazem o produto se tornar obsoleto antes mesmo que as obsolências cosmética ou artificial sejam adicionadas a ele)". Assim, para alguns autores, o design se tornou um fenômeno marginal, ou seja, limitado a decorar os projetos dos produtos industriais. Destacaram-se, neste período, os designers americanos Raymond Loewy, Henry Dreyfuss, Norman Bel Geddes e Walter Dorwin Teague.

5 A década de 50 marca o aparecimento da TV e do auge das revistas, principalmente aquelas ilustradas, como meios de comunicação de massa. Foi com o auxílio desses meios que a indústria americana começou a enfatizar a moda e o styling para então estimular o consumidor a adquirir produtos com o objetivo de substituir aqueles que, apesar de servíveis, já se encontravam obsoletos e "fora de moda". Tratava-se da necessidade mercadológica e o design se tornou uma poderosa ferramenta para lidar com esse fato. "Nesse contexto, os designers se viam encarregados cada vez mais de introduzir mudanças de natureza principalmente cosmética, prática que atingiu o seu ápice na indústria automobilística americana entre as décadas de 1930 e 1960" (CARDOSO; 2004; p.134). 
National Science Foundation, por exemplo, patrocinou três testes utilizando TVI em operadoras de canais a cabo para educação, serviços comunitários e treinamentos. O Departamento de Saúde dos EUA, Education and Welfare (DHEW), patrocinou serviços de TVI para promoção de cuidados com a saúde (CAREY, 1996, p.05). Nessa década, começaram também a surgir novos produtos midiáticos que segmentaram os meios de massa e distribuiam a mensagem (desmassificadores). Máquinas de xerox, aparelhos de fax, videogames, videocassetes e revistas especializadas para públicos distintos compõem esta categoria de aparelhos. A autora Lúcia Santaella caracteriza este momento com o surgimento da cultura das mídias. A televisão, no entanto, mesmo sendo característica forte da cultura de massa, ao invés de sucumbir com o surgimento das novas mídias continuou forte, pois o desenvolvimento da tecnologia traz novas maneiras de difusão de transmissões e ela ganha dimensões maiores chegando a lugares aonde antes não chegava. O fato mostra que, mesmo com a tendência à segmentação das massas e, conseqüentemente, o surgimento da cultura das mídias, a cultura de massa continua e coexiste com a das mídias (SANTAELLA, 2004, p.79-81).

Assim como no resto do mundo, no Brasil a TV é baseada no modelo de radiodifusão, que se caracteriza pela emissão de ondas que são captadas direta e livremente pelo telespectador, através dos televisores, ou seja, por meio de aparelhos receptores. Este modelo tem como principal característica a transmissão de informações pela emissora de TV e o telespectador não pode opinar nem interferir na programação que está assistindo. Foi nos anos 80 que começaram a surgir os primeiros microcomputadores pessoais. Os consumidores aprenderam a interagir e a buscar as informações que desejavam e se tornaram, além de consumidores, usuários. A recepção aparece como bidirecional e as telas dos computadores exibem interfaces que estruturam a interação entre usuário e informação e/ou produto. "Isso significa que começou a mudar aí a relação receptiva de sentido único com o televisor para o modo interativo e bidirecional que é exigido pelos computadores (SANTAELLA, 2004, p.81)".

Nos anos noventa, a TVI tenta também oferecer aos espectadores serviços oferecidos aos usuários de Internet, como: enviar e receber e-mails, navegar e realizar compras online. Mas, nesta época, estes tinham o computador pessoal como algo mais adequado para tal, e percebiam a TVI como algo futuro, mas que ainda iria demorar muito para funcionar e ser realmente atrativo. Por outro lado, iniciou-se a implantação da TV Digital no mundo, fato que impulsionou ainda mais 
o desenvolvimento da TVI. Apenas a partir do final de 2003 o Brasil intensificou suas pesquisas em TV Digital devido à instituição do SBTVD (Sistema Brasileiro de TV Digital). Hoje, o Video on Demand (VOD) surge no mundo dos canais de TVs a cabo, apresentando a infraestrutura digital necessária para permitir aplicações interativas. Os provedores de satélites estão desenvolvendo projetos de TVI e PVRs ${ }^{6}$ (Personal Video Recorder). Um bom exemplo de serviço oferecido pela TV Digital é a sincronia entre duas telas, que está se tornando uma necessidade nos programas cujo conteúdo é de esportes e eventos.

Nota-se, portanto, que apenas após o advento da Internet e o crescente desenvolvimento do conceito de interatividade nos meios de comunicação, o consumidor passou a ser autônomo em relação às suas escolhas, pois os meios interativos trouxeram este hábito. Mas isso não ocorreu de repente, estas características de maior diversidade e liberdade de escolhas inerentes aos meios interativos foram, a princípio, sendo introduzidas aos poucos pela cultura das mídias (SANTAELLA, 2004, p.82). Para Santaella, isso significa que estamos entrando em uma terceira era midiática, a cibercultura (2001, p.82).

Tecnicamente, para que o usuário tenha acesso a partir do seu computador pessoal a informações em formato de documentos, imagens, sons e vídeos, estas têm que conviver em um único espaço. E, para que convivam neste espaço, estas informações são traduzidas e codificadas para o sinal digital composto de números 0 e 1. A mistura destes diferentes formatos de informações codificadas em sinal digital chama-se multimídia. As quatro formas principais da comunicação humana: o documento escrito, o áudio-visual, as telecomunicações e a informática, ao serem digitalizadas sofrem um processo de convergência de mídias (SANTAELLA, 2004, p.82). 
1.1 0 Design e seu papel na comunicação: linha do tempo. 
TELEVISÃO

\section{7}

O Barão Berzelius conseguiu isolar um elemento chamado Selênio, dotado da propriedade de desprender elétrons quando em presença da luz (SAMPAIO, 1984, p.185).

\section{3}

O inglês Willoughby Smith May estudou o efeito fetoelétrico do Selênio e produziu a primeira célula fotocondutiva, fato que originou as primeiras pesquisas sobre o tubo de imagem de uma câmara de TV (SAMPAIO, 1984, p.185).

\section{5}

Alexander Graham Bell, um jovem americano, professor de fisiologia vocal na Universidade de Boston, inventou o telefone com a ajuda de seu auxiliar Thomas Watson, e patenteouo no ano seguinte, depois de realizar com sucesso a primeira transmissão da palavra falada (SAMPAIO, 1984, p.36).
DESIGN

\section{1}

O inglês William Morris (1834 - 1896), socialista, poeta, desenhista, tipógrafo e mestre de vários ofícios, abriu sua primeira firma: a Morris, Marshall, Faulkner \& Co, e começou a produzir com seus sócios e artistas renomados da época objetos decorativos e utilitários (móveis, tecidos, tapetes, vitrais e papeis de parede), enfatizando o bom gosto e alta qualidade dos seus produtos. A firma, em seus prospectos, se definia como "Trabalhadores artísticos especialistas em Pintura, Tecidos, Mobiliário e Metais”. Assim, Morris conseguiu, até certo ponto, elevar o status dos artesãos ao colocá-los lado a lado ao artista bem como o artefato à arte (SPARKE et al., 1987, p.21,24).

\section{2}

Quase dez anos depois, o movimento Arts and Crafts $^{11}$ atingiu a sua maioridade com a formação de grêmios e sociedades profissionais. O pioneiro foi o grêmio de São Jorge fundado pelo crítico e escritor inglês John Ruskin, que inspirou e serviu de modelo para sociedades posteriores (SPARKE et al., 1987, p.27-26).

110 Movimento Arts and Crafts surgiu na Grã Bretanha como uma reação ideológica aos efeitos da industrialização no século XIX (SPARKE, et al. 1987, p.12). 


\section{9}

Dez anos antes da proclamação da república no Brasil, o imperador, D. Pedro II, criou a Companhia Telefônica do Brasil, que autorizava a construção e operação de linhas telefônicas no Rio de janeiro e seus subúrbios, e Niterói (SAMPAIO, 1984, p.39-40).

\section{0}

O francês Maurice Le Blanc propôs o uso de um fio condutor para transmitir imagens sucessivas, em série, representadas por objetos em movimento. Ele havia chegado ao princípio básico do funcionamento do cinema e da televisão: a transmissão de componentes luminosos por varredura rápida em linhas horizontais sucessivas (SAMPAIO, 1984, p.186-187).

\section{5}

Morris dissolveu a sociedade e montou sozinho uma nova firma, a Morris \& Company (SPARKE et al., 1987, p.27-26).

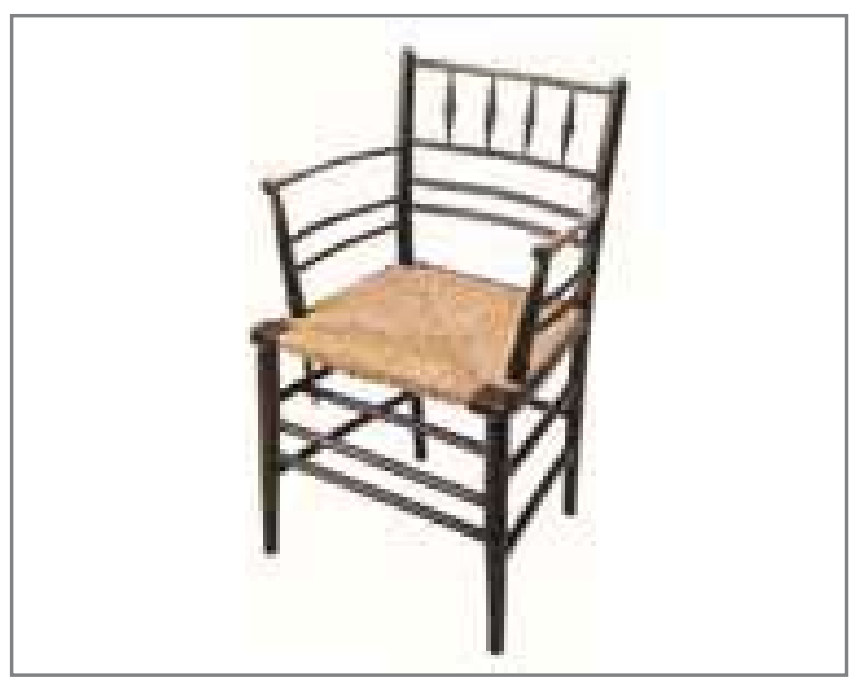

Fig 01. Cadeira da linha Sussex fabricada pela Morris \& Co. a partir de 1860 (DENNIS, 2004, p. 70).

\section{2}

Foi fundado o grêmio do Século, impulsionado pelo entusiasmo de Morris de reviver o artesanato manual e devolver ao artesão o status merecido. Os membros mais experientes deste grêmio eram o arquiteto e designer Arthur Heygate Mackmurdo (1851 1942) e o ilustrador e designer Selwyn Image (1849 - 1930) (SPARKE et al., 1987, p.27-28). 


\section{4}

O alemão Paul Nipkow inventou um sistema eletromecânico de varredura por meio de um disco que permite a recomposição de imagens por sinal elétrico transmitido por fios. Nipkow desenhou um disco sobre um papel fazendo perfurações em forma de espiral: era o embrião da TV. Os trabalhos deste inventor influenciaram algumas linhas de desenvolvimento da televisão atual, como, por exemplo, o sistema desenvolvido por Jonh Logie Baird na Inglaterra. Nipkow é denominado fundador da técnica da TV, pois patenteou a proposta de transmissão de imagens à distância (SOUZA, 2002, p.4).

\section{5}

Heinrich Rudolf Hertz, físico alemão, inicia pesquisas sobre a teoria das ondas eletromagnéticas, que abriram caminho para invenções com a televisão e o rádio. As ondas eletromagnéticas descobertas por Hertz foram denominadas Ondas Hertzianas em sua homenagem (SAMPAIO, 1984, p.24).

\section{4}

Foi fundado o Grêmio dos Trabalhadores da Arte. As figuras de mais destaque deste grêmio eram William Letharby (1857 - 1931) e Walter Crane (1845 - 1915) que difundiram as idéias e intenções do movimento, promovendo a educação em todas as artes e ofícios visuais através de conferências, discussões e outros meios, com o objetivo de causar benefícios à comunidade (SPARKE et al., 1987, p.29).

\section{8}

O discípulo de Morris, Charles Robert Ashbee (1863-1942), que era membro do Grêmio dos Trabalhadores da Arte, fundou o Grêmio dos Artesãos. Ashbee visionava um grupo de artesãos felizes trabalhando à mão e produzindo para a comunidade. (SPARKE et al., 1987, p.33). 


\section{7}

O professor português, Adriano de Paiva publicou neste ano o artigo intitulado "A Telescopia elétrica" (traduzido para o francês e o inglês), inspirado pelo sucesso do invento do telefone por Graham Bell. (PEREIRA, 1999, disponível em: <http://si.porto.ucp.pt/ internal/mestrado/mest99/Teoria_media/ tv/TEXTOS\%20FINAIS/1_A\%2OInvencao.htm>. Acessado em: 3 de Mar de 2007).

\section{5}

Os alemães Julius Elster e Hans Geitel produziram a célula fotoelétrica (SAMPAIO, 1984, p.185).

\section{7}

O inventor italiano Gugliemo Marconi fez as primeiras emissões de sinais transmitidos por meio das ondas heztzianas (SAMPAIO, 1984, p.44-46).

\section{0}

0 movimento Art Nouveau (arte nova) influenciado pelo Arts and Crafts e por movimentos artísticos como o Simbolismo ${ }^{12}$, espalhou-se pela Europa. A Art Nouveau buscava o tratamento da decoração superficial. Os artistas e designers inspiravam-se em artes exóticas e incorporavam tendências contemporâneas (SPARKE et al., 1987, p.40).

\section{0}

As empresas pretendiam dar mais qualidade aos seus produtos na busca de se estabelecerem no mercado mundial. Com isso, as curvas da Art Nouveau foram dando lugar a uma estética mais simples e racional. Muitas nações tentaram aplicar a arte daquela época à indústria e concluíram que o estilo simples e racional refletia com boa clareza os valores e processos de produção da máquina simbolizando o novo século e a apologia à tecnologia (SPARKE et al., 1987, p.72). 


\section{0}

O cientista russo Constantin Perskyi introduz o termo televisão que vem da junção das palavras tele (longe, em grego) e videre (ver, em latim). O termo foi divulgado por Perskyi no Congresso Internacional de Eletricidade, na Exposição Mundial de Paris. (LANGE, 2002, disponível em: <http://histv.free.fr/perskyi/ perskyi2.htm>. Acessado em 03 de Mar de 2007).

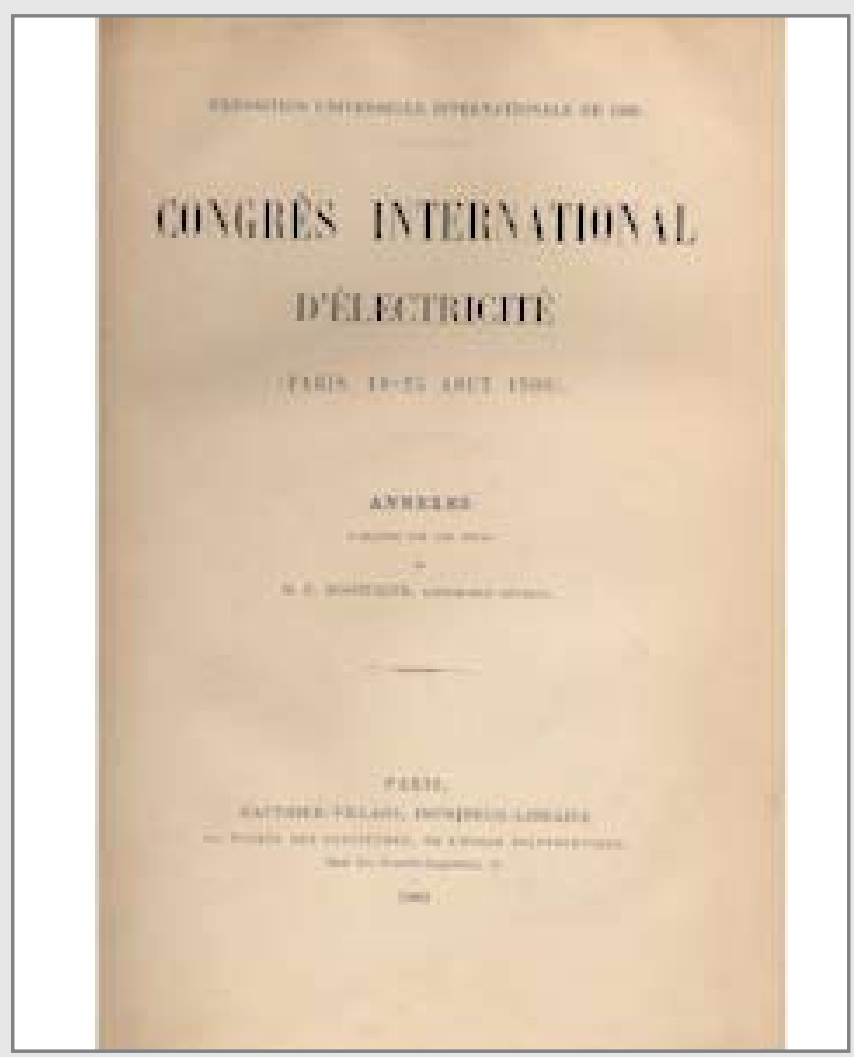

Fig 02. Constantin PERSKYI, "Télévision au moyen de l'électricité", in EXPOSITION UNIVERSELLE INTERNATIONALE DE 1900, Congrès international d'électricité (Paris, 18-25 Outubro de 1900). (Disponível em: <http://histv.free.fr/perskyi/perskyi2.htm>. Acessado em 03 de Mar de 2007)

\section{7}

Formou-se na Alemanha a Deutsche Werkbund $^{13}$ (Liga Alemã do Trabalho) com o objetivo de valorizar o trabalho relacionando arte, indústria e artesanato, através da educação, propaganda e debates sobre questões ligadas à produção. Teve como representantes arquitetos como Walter Gropius (1883 - 1969), Hermann Muthesius (1861 - 1928), Henry van de Velde (1863 - 1957), e profissionais de outras áreas envolvidas com o processo de criação, desenvolvimento, produção e comercialização de mercadorias (SPARKE et al., 1987, p.80; BOMFIM, 1995, p.91-92).

\section{3}

Gropius, preocupado em expor suas idéias sobre a arte e a indústria, escreve um artigo denominado "Die Entwicklung moderner industriebaukunst" (0 desenvolvimento da moderna arte de construir) (MALDONADO, 1991, p.55-56).

13 A Deutsche Werkbund objetivou a criação de um padrão formal e, em seguida, a legitimação dessa linguagem e sua aplicação na produção da mesma (BOMFIM, 1995, p.91-92). 


\section{1}

Em Saint John, Marconi demonstra uma comunicação entre a Europa e a América, mediada pelo oceano, provando que a propagação das ondas de rádio tinha vencido a curvatura terrestre (SAMPAIO, 1984, p.46).

\section{9}

0 professor francês Georges Rignoux descreveu o sistema do aparelho de televisão utilizando um tambor giratório espelhado e um mosaico de células foto elétricas de Selênio para esquadrinhar, transmitir e apresentar imagens em uma tela (LANGE, 2002. Disponível em: <http://histv2.free. $\mathrm{fr} /$ rignoux/rignoux.htm>. Acessado em 03 de Mar de 2007).

\section{1}

Em maio, o Dr. Boris Rosing de São Petersburgo, Rússia, adotou o tambor espelhado de Rignoux para desenvolver um sistema semelhante ao dele, mas que apresentava as imagens em um tubo de raios catóditos. Vladimir Zworykin (1889 - 1982) foi seu assistente. Boris Rosing morreu na Revolução Russa (SARNOFF COLLECTION, 2001-2002. Disponível em: <http: / / www.davidsarnoff.org/rcatechtv. html>. Acessado em 03 de Mar de 2007).

\section{4}

Aconteceu em Colônia na Alemanha a Exposição da Werkbund onde Walter Gropius e Adolf Meyer apresentaram o modelo de fábrica com escadas e cobertura de vidro promovendo a arquitetura e o design motivados pela máquina (SPARKE et al., 1987, p.81).

\section{5}

Foi criada a Associação de Desenho e Indústrias na Inglaterra com o objetivo de unir a população, designers e operários para que, assim, os artesãos regressassem às empresas comerciais (SPARKE et al., 1987, p.87).

\section{7}

Ao final da Primeira Guerra Mundial, iniciaramse discussões de idéias sobre a preocupação com a máquina e o movimento Modernista. 0 movimento Modernista holandês se divulgou por meio da publicação De Stijl em 1917 e consistiu na utilização do mínimo de elementos visuais como de linhas retas e cores básicas buscando comunicar verdades universais (SPARKE et al., 1987, p.88). 


\section{3}

O inglês Jonh Logie Baird realizou uma transmissão de imagens (SAMPAIO, 1984, p.189).

\section{9}

Nos Estados Unidos, a American Marconi Company se transforma na Radio Corporation of America (RCA) que além de explorar a radiotelegrafia, também deteve conhecimentos sobre a radiofonia produzindo transmissores e receptores de rádio (SAMPAIO, 1984, p.48-49).

\section{5}

Nos EUA, o imigrante russo naturalizado americano, Vladimir Zworykin patenteou o iconoscópio, um tubo a vácuo com uma tela de células fotoelétricas que fazia uma varredura eletrônica da imagem (SAMPAIO, 1984, p.190).

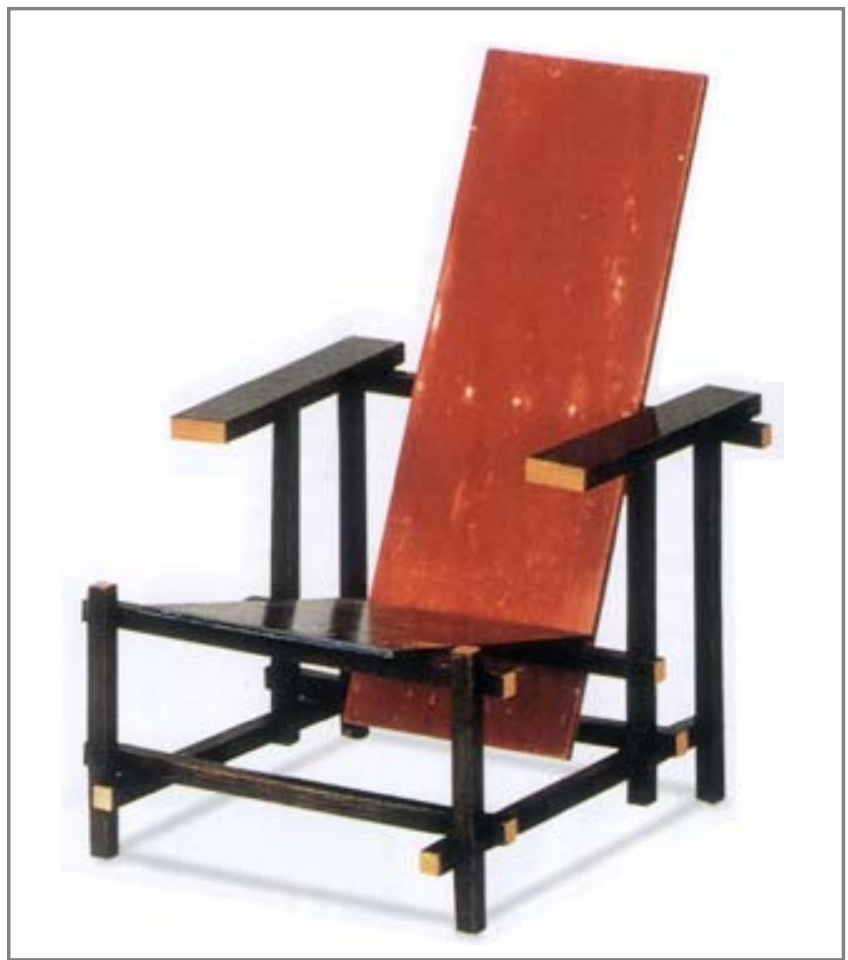

Fig 03. 1917, Cadeira Vermelha e Azul de Gerrit Rietveld (SPARKE, et al. 1987, p.74).

\section{9}

Foi fundada a escola da Bauhaus ${ }^{14}$ na cidade de Weimar (Alemanha) pelo arquiteto alemão Walter Gropius. A Bauhaus foi uma escola de design, artes plásticas e arquitetura de vanguarda, com uma proposta e um método de ensino revolucionários. Surgiu por meio da junção da Weimar School of Arts and Crafts e da Weimar Academy of Fine Arts. Funcionou na Alemanha entre 1919 e 1933 com a chegada do poder do partido Nazista (SPARKE et al.,1987, p.96; CARDOSO, 2004, p.117).

14 Bauhaus é conhecida como Das Staatliches Bauhaus que significa literalmente, casa estatal de construção (CARDOSO, 2004, p.116). Na Bauhaus prevalesceram opiniões de artistas e artesãos que buscavam legitimar o design ao afastá-lo da criatividade individual e aproximá-lo de uma pretensa objetividade técnica e científica (CARDOSO, 2004, p.120-121). 


\section{6}

O inventor escocês John Logie Baird realiza as primeiras transmissões de imagens sem utilizar fios entre London e Glasgow, através do sistema mecânico baseado no invento de Nipkow (disco de Nipkow). A BBC inicia a emissão experimental de televisão, recorrendo ao sistema de Baird. Neste mesmo ano a RCA (Radio Corporation of America) contratou o cientista russo Wladmidir Zworykin para a divisão de pesquisas técnicas (SAMPAIO, 1984, p.189-190).

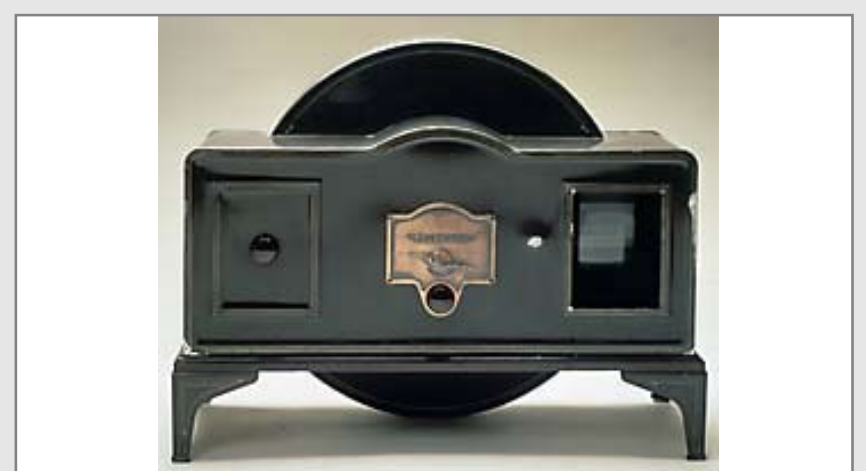

Fig 04. A Televisão mecânica inglesa de 1926, tinha uma pequena tela posicionada à direita e media $56 \mathrm{~cm}$ de altura. Este aparelho não conseguia transmitir som e imagem ao mesmo tempo (TAMBINI, 1999, p.94)

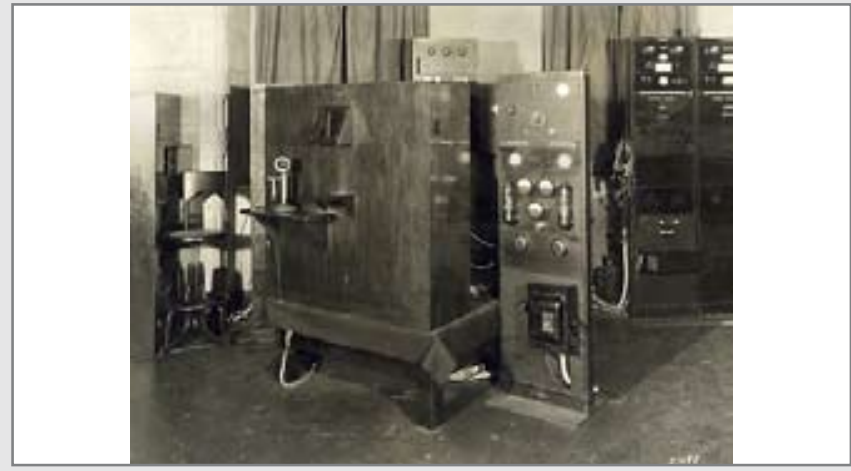

Fig 05. Aparelho receptor utilizado na primeira demonstração americana de Televisão em 07 de abril de 1927 (Disponível

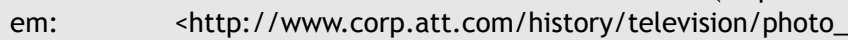
tvequipment.html>. Acessado em 25 de Fev de 2007).

\section{3}

O pintor húngaro Lazlo Moholy-Nagy escreve a primeira declaração da nova tipografia "Usamos todos os tipos, tipos de todos os tamanhos, formas geométricas, cores, etc." (HOLLIS, 2001, p.54).

Walter Gropius organiza na Bauhaus a exposição "Arte e Técnica - Uma Nova Unidade”. Gropius se interessava pela experiência mais objetiva da forma (SPARKE et al., 1987, p.95).

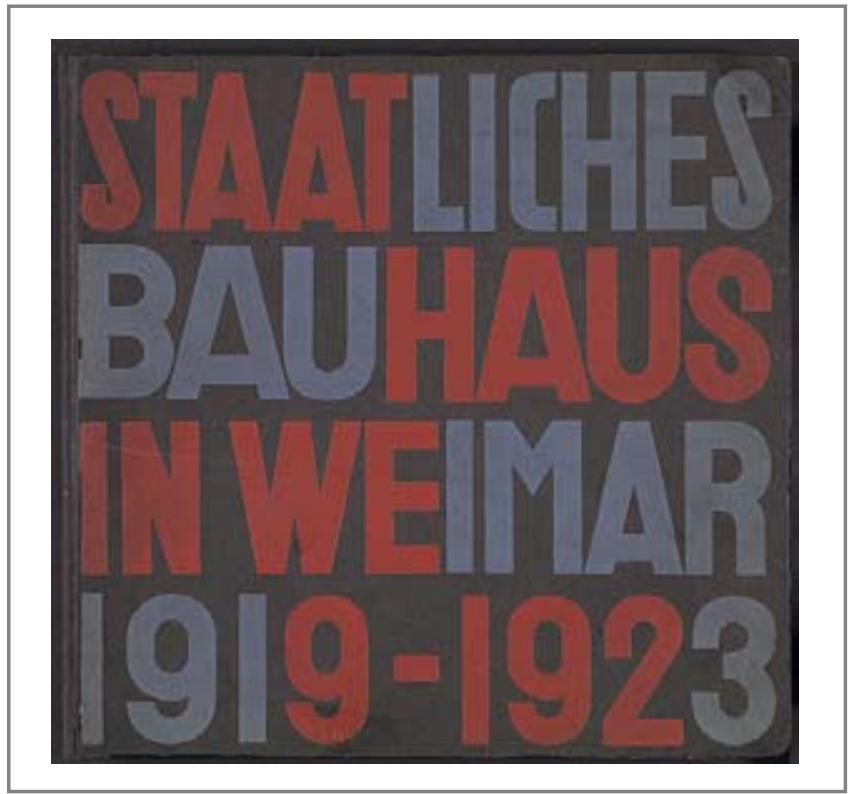

Fig 06. Staatliches Bauhaus in Weimar, 1919-1923. Livro que expôs os objetivos e realizações da Bauhaus não só em seu conteúdo como também em seu design (HOLLIS,2001, p.54) . 


\section{8}

J. L. Baird fez testes satifatórios de transmissão à cores na Inglaterra (SAMPAIO, 1984, p.245).

\section{9}

Nos Estados Unidos (Camden, New Jersey), a Rádio Corporation of América (RCA) apresentou o primeiro sistema prático de TV completamente eletrônico (SAMPAIO, 1984, p.190). Na busca de sua linguagem própria e formas de explorar o novo meio, a BBC de Londres, inaugurada em 14 de novembro de 1922, seria a pioneira do radioteatro, ao transmitir uma radiofonização da peça de Shakespeare "Noite de Reis". A estação britânica, BBC em 30 de setembro realiza em Londres a primeira transmissão de televisão em caráter experimental utilizando o sistema de Baird (SOUZA, 2002, p.7).

\section{4}

O designer funcionalista Rudolf Koch cria a família de tipos Neuland. Todas as formas de letra que a Bauhaus criou tinham uma base estritamente geométrica. Esta foi a maneira encontrada pelos designers de fugir ao estilo renascentista e a tradição germânica do estilo pesado e artesanal (HOLIS, 2001, p.53).

\section{5}

Ocorre a Exposição de Paris que se notabilizou por popularizar o estilo Art Deco. Nesta exposição o arquiteto francês Pierre Jeanneret, mais conhecido como Le Corbusier, apresentou seu Pavillon de l'Esprit Nouveau (SPARKE, et al. 1987, p.100). Neste mesmo ano, na Alemanha, a Bauhaus mudouse para Dessau e Gropius desenhou o edifício de acordo com os princípios do movimento arquitetônico moderno: paredes brancas, telhados planos e janelas com marcos metálicos (SPARKE et al., 1987, p.96). 
1930

A Marconi Wireless Telegraph Company (MWT) iniciou pesquisas sobre o envio de mensagens de texto por meio da televisão (Disponível em: <http://www.kinema.uwaterloo.ca/baird962. htm>. Acessado em 04 de Mar de 2007).

\section{2}

Começou nos Estados Unidos a industrialização de transmissores e receptores de TV (SAMPAIO, 1984, p.192).

\section{4}

Inaugura-se a Marconi-EMI Television Company Ltd., dirigida por Isaac Shoenberg que foi colega de Zworykin, na Rússia, antes da Primeira Guerra Mundial. Inicia-se uma competição entre as equipes de investigação da Television Limited e da Marconi-EMI, que lutam pela exclusividade da adoção de um dos sistemas pela BBC. Para tentar anular a concorrência, a Television Limited de J. L. Baird adquire a patente do sistema electrônico de televisão aperfeiçoado pelo americano Philo Farnworth. (Disponível em: http://www.kinema.uwaterloo.ca/baird962. htm. Acessado em 04 de Mar 2007).

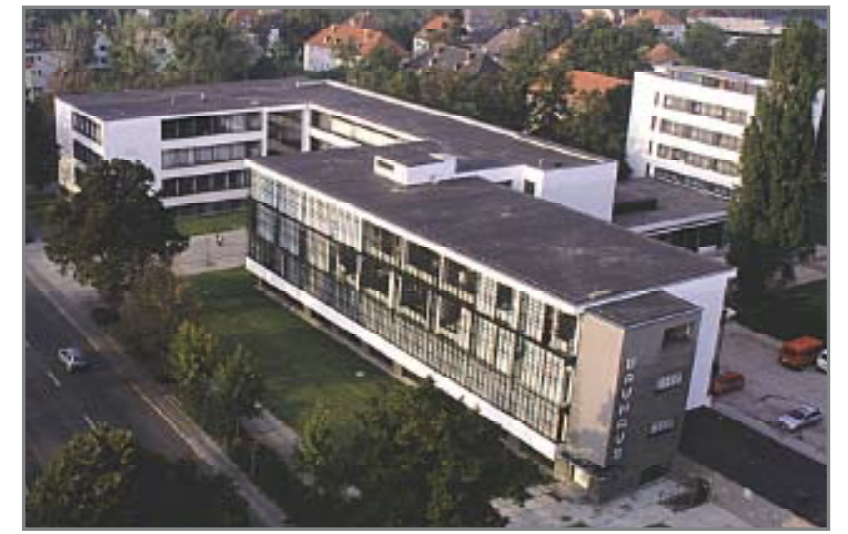

Fig 07. A Bauhaus mudou-se de Weimar para Dessau em 1925 o que trouxe a oportunidade de se criar condições ideais de trabalho em um novo edifício com design próprio. 0 novo edifício foi inaugurado em dezembro de 1926 e se tornou um ícone do Modernismo Clássico. (Disponível em: <http://www.bauhaus-dessau.de/bhimages/ bauhausluft.jpg>. Acessado em 04 de Mar de 2007).

\section{6}

Na Alemanha, foi decidido completar o nome do Instituto da Bauhaus com o acréscimo Hochschule fur Gestaltung (Escola Superior de Criatividade), para precisar melhor a sua tarefa fundamental (MALDONADO, 1991, p.52).

\section{8}

Jan Tschichold, um dos fundadores do design gráfico moderno, lançou o livro Die Neue Typographie (A Nova Tipografia). O autor codificou suas experiências tipográficas com tipos mais despojados e geométricos que procuravam uma estética adequada às máquinas. Tschichold também se baseou em esquemas assimétricos de paginação integrando outros meios como a fotografia. A publicação contribuiu ao vanguardismo que separa a escrita tradicional da imagem (CARDOSO, 2004, p.115). 


\section{6}

- Television Committee apresenta um relatório recomendando a adoção de um sistema de televisão de alta definição (o que na época compreendia 240 linhas a 24 imagens por segundo). Os dois sistemas, o de Baird (Television Limited) e o da EMI são aprovados, no entanto foram obrigados a manter compatibilidade nos televisores. Em Abril, a EMI apresenta à BBC um sistema de televisão de 405 linhas, claramente superior ao sistema de Baird, levando a BBC a optar em pouco tempo pelo encerramento das emissões no sistema de 30 linhas (Disponível em: <http://www.kinema.uwaterloo.ca/ baird962.htm>. Acessado em: 04 de Mar de 2007). A empresa americana RCA apresentou um protótipo de televisão, instalando 150 receptores em Nova York. Foram exibidos desenhos animados do personagem gato Félix (SOUZA, 2002, p.5).

\section{7}

Em 4 de fevereiro, a BBC adota definitivamente o sistema EMI (Disponível em: <http:// www.kinema.uwaterloo.ca/baird962.htm>. Acessado em: 04 de Mar de 2007).

\section{9}

$\mathrm{O}$ arquiteto alemão Ludwig Mies van der Rohe cria para o pavilhão da Exposição Mundial de Barcelona, a cadeira Barcelona, que responde às determinações funcionais de caráter técnico-utilitário - solidez e conforto, a curva suave do espaldar e a inclinação do assento convidam a se recostar (TAMBINI, 1999, p.59).

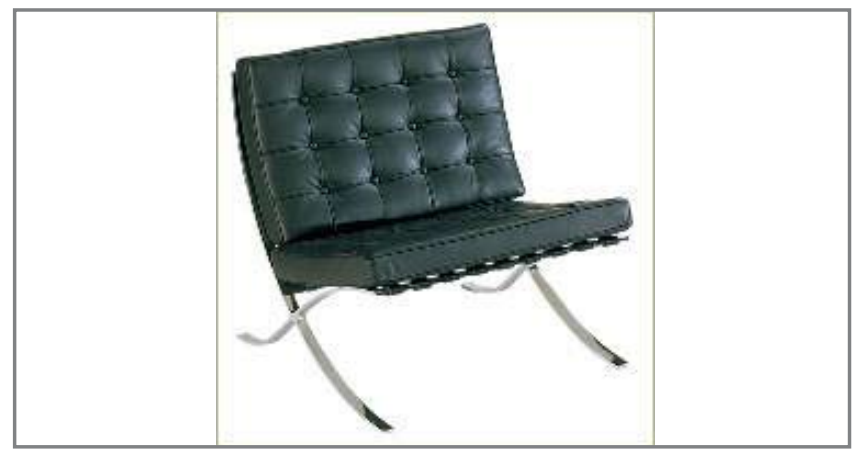

Fig 08. Cadeira Barcelona, 1929 (TAMBINI, 1999, p.59).

\section{3}

$\mathrm{O}$ designer Henry Beck, incentivado pelo $\mathrm{CIO}$ (Chief of Information Office) da recém criada EmpresadeTransportes deLondres, FrankPick, desenvolveu o mapa diagramático do metrô de Londres. Ele distorceu geograficamente as rotas em linhas verticais, diagonais e em 45 graus facilitando dessa forma a leitura do mapa (LIVINGSTON, 2003, p.28).

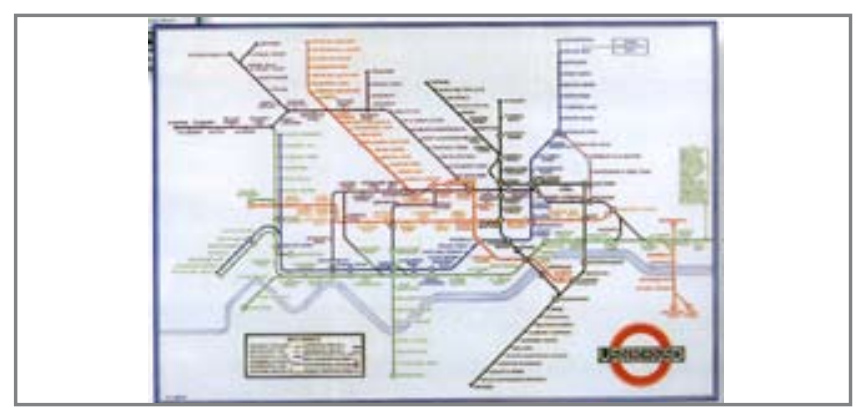

Fig 09. Mapa do metrô de Londres, 1933 (TAMBINI, 1999, p.26). 


\section{8}

O francês Georg Valensi patenteou o sistema no qual partículas coloridas que compõem a imagem total são transmitidas sucessivamente e em sequência por meio de impulsos elétricos. Este sistema foi aperfeiçoado e nasceu o sistema SECAM francês (SAMPAIO, 1984, p.245).

\section{9}

Foram inauguradas oficialmente as transmissões de televisão nos Estados Unidos com a abertura da Feira Mundial de Nova York. O discurso do presidente Roosevelt foi visto em alguns receptores, pouco mais de 100, que custavam entre 200 e 600 dólares (SOUZA, 2002, p.5).

\section{0}

A RCAe a NBC iniciam investigações no sentido de desenvolverem sistemas de televisão em cores (PEREIRA, Disponível em: <http:// si.porto.ucp.pt/internal/mestrado/mest99/ Teoria_media/tv/TEXTOS\%20FINAIS/1_ A\%20Invencao.htm>. Acessado em 03 Mar de 2007).

\section{4}

Ocorre nos Estados Unidos, no Museum of Modern Art de Nova York, a exposição Machine Art organizada por Ph. Johnson. Esta manifestação contribuiu fortemente para a idéia do good design ${ }^{15}$ e conscious design ${ }^{16}$, em oposição ao styling ${ }^{17}$ (MALDONADO, 1991, p.72). O termo styling, segundo Cardoso, tem sido aplicado de forma muitas vezes pejorativa a trabalhos de renomados designers americanos da época de 30 e 40, como, por exemplo, Raymond Loewy. Estes profissionais eram acusados de praticar um design cosmético, que apenas tratava da aparência estética superficial do produto e, consequentemente, da sua venda. Por outro lado, tiveram grande importância histórica, pois foram responsáveis pela introdução de uma maior preocupação com o mercado como fator a ser considerado na elaboração de projetos (CARDOSO, 2004, p.131-132).
15 Objetos considerados como good design são aqueles que, pela sua particular qualidade formal, merecem ser considerados exemplares (MALDONADO, 1991, p.71).

16 Conscius design significa design consciente, ou seja, aquele que se aplica a objetos que seguem a orientação produtivista-funcionalista antes da estéticoformal (MAIDONADO, 1991, p.72-73).

170 styling se define, segundo Tomás Maldonado, como uma modalidade do design industrial que procura tornar o produto superficialmente atratente em detrimento da sua qualidade e conveniência; que procura seu envelhecimento artificial, em vez de prolongar sua fruição e utilização (1991, p.46-47). 


\section{1}

Foi criado o padrão de imagem da TV americana e instituído no início da década de 50 pelo National Television System Committee (NTSC), que em 1953 adotou o atual sistema de transmissão de televisão NTSC (SOUZA, 2002, p.5).

\section{1}

A estação televisiva de Nova York - WNBT transmite o primeiro anúncio comercial, um spot de dez segundos por apenas 9 dólares, captado ao vivo e anunciando uma marca de relógios. Inicia-se assim o que viria a se tornar a principal fonte de rendimento deste meio de comunicação. Nessemomentotambémseinicia a era da televisão comercial, cujo principal objetivo é ampliar sua audiência para garantir lucro (PEREIRA, 1999, Disponível em: <http: // si.porto.ucp.pt/internal/mestrado/mest99/ Teoria_media/tv/TEXTOS\%20FINAIS/1_ A\%20Invencao.htm>. Acessado em 3 de Mar de 2007).

\section{6}

Nos Estados Unidos, com cabos coaxiais e através da propagação espacial, as redes nacionais de rádio passaram a transmitir também programações de televisão (SAMPAIO, 1984, p.194).

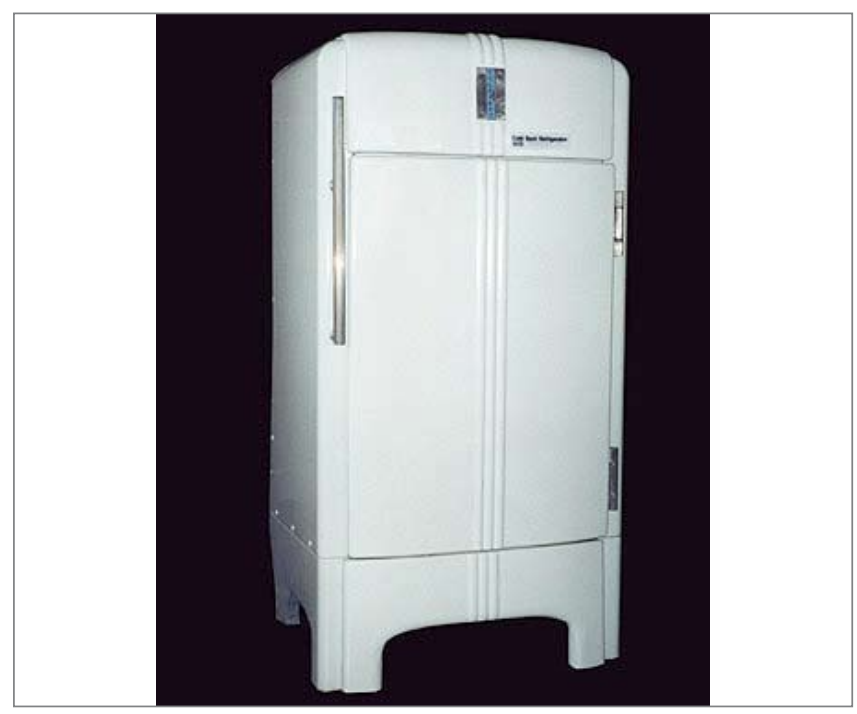

Fig 10. Geladeira Coldspot, projetada por Raymond Loewy para a loja Sears em 1934. O projeto dessa geladeira foi um êxito de vendas no século $X X$, ele concilia exigências técnicas com expectativas estéticas (CARDOSO, 2004, p.133).

\section{7}

O arquiteto francês Le Corbusier, a convite do governo brasileiro, coordenou um grupo de arquitetos no Brasil (Lucio Costa, Oscar Niemayer, Afonso Reidy, entre outros) no desenvolvimento do Palácio da Cultura do Rio de Janeiro (BOMFIM, 1995, p.120). Neste ano, foi fundada a "Nova Bauhaus" em Chicago, por iniciativa de Moholy-Nagy, na qual participavam ex-alunos da Bauhaus, entre outros. A escola se firmou com o nome de Institute of Design em 1944 e logo foi absorvida pelo Illinois Institute of Technology em 1949 (CARDOSO, 2004, p.167). 
1948

Surge, na costa noroeste dos Estados Unidos, a primeira cadeia de TV a cabo. Isso se deve ao relevo acidentado do montes Appalachians que impediam a propagação das ondas hertzianas até os vales habitados (Disponível em: <http: / / si.porto.ucp.pt/internal/mestrado/mest99/ Teoria_media/tv/TEXTOS\%20FINAIS/1_ A\%20Invencao.htm>. Acessado em 03 Mar de 2007).

\section{9}

Começaram a surgir televisores mais acessíveis a população como a Bakelite TV da Bush, comercializada na Inglaterra (TAMBINI, 1999, p.94).

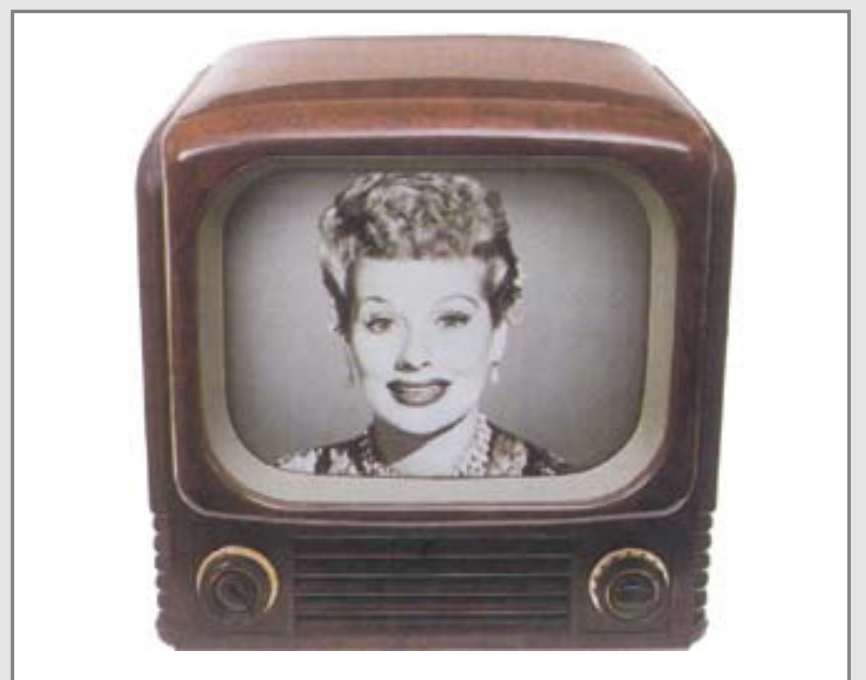

Fig 11. Bush TV12, modelo lançado em 1949 a baixo custo. O programa de TV "I love Lucy" lançado em 1951 (TAMBINI, 1999, p.94).

\section{8}

Em Nova York, no Museum of Modern Art, acontece a primeira exposição da Bauhaus com objetivo de ilustrar a época de Gropius (19191928). O resultado foi uma exposição idealizada do que foi a Bauhaus: uma comunidade de artistas-professores que trabalharam em harmonia para o desenvolvimento de uma nova didática e forma de criar objetos de uso. Esta versão da Bauhaus teve impacto sobre a corrente cultura americana e abriu caminhos para que determinados objetos produzidos pela indústria pudessem ser considerados como good design (MALDONADO, 1991, p.71).

\section{9}

Ocorre a Feira Mundial de Nova York onde, em suas instalações e produtos futuristas, dominava a tendência aerodinâmica americana representando êxito para os designers americanos, para as novas tecnologias e para o design como fator de capacitação de mercado (SPARKE et al., 1987, p.137). 


\section{0}

Em 18 setembro inaugurou-se a primeira emissora de TV da América do Sul. A TV Tupi, canal 3, em São Paulo, com sistema baseado no norte-americano. A TV Tupi pertencia ao jornalista Assis Chateaubriand, dono dos Diários Associados. Os primeiros anos da televisão no Brasil foram marcados por falta de recursos e improvisações, como a falta de equipamentos televisores para recepção de imagens emitidas e queima de câmeras (MATTOS, 2000, p.92-93).

\section{1}

Assis Chateaubrian inaugura a TV Tupi no Rio de Janeiro, instalada provisoriamente nas instalações da Rádio Tamoios, sendo que sua antena foi colocada no Pão de Açúcar. Também nesse ano foi iniciada a produção de televisores da marca Invictus (MATTOS, 2000, p.96-97).

\section{4}

Formou-se na Inglaterra o Conselho de Desenho Industrial, pois com o término da guerra o país sentiu a necessidade de rever sua atitude em relação ao papel do design nos produtos de consumo de massa e ir além dos ideais artesanais para que assim pudesse competir no mercado internacional (SPARKE et al., 1987, p.156).

\section{6}

O Conselho de Desenho Industrial realizou a exposição de design - England can make It - no museu Victoria and Albert, em Londres, onde a maioria dos objetos expostos estavam destinados à exportação e poucos deles tinham um design verdadeiramente inovador, a maioria eram simples modificações dos designs dos anos 30 (SPARKE et al., 1987, p.156). 


\section{2}

Começaram a ser encontradas algumas soluções técnicas para o desenvolvimento dos sistemas de televisão em cores. 0 National Television Standards Committee (NTSC), estabeleceu normas para a televisão americana em cores e assegurou a compatibilidade destes sistemas com o de televisão preto e branco. Surgiram três sistemas propostos pela indústria americana: Field Sequential Method da CBS; Dot Sequential Method, da RCA e o Line Sequential Method, da CTI (PEREIRA, Disponível em: <http://si.porto.ucp.pt/ internal/mestrado/mest99/Teoria_media/ tv/TEXTOS\%20FINAIS/1_A\%20Invencao. htm>. Acessado em: 03 de Mar de 2007).

Também neste ano surge o primeiro controle remoto: o "Lazy Bone". Este controle remoto foi fabricado pela empresa americana Venus.

O Lazy Bone era vendido com um cabo grande que era ligado a TV. Quando o usuário pressionava seus botões o canal de TV mudava na tela (Disponível em: < http://www.itvt. com/etvwhitepaper-4.html>. Acessado em: 29 de Abr de 2007).

\section{9}

As primeiras iniciativas de design na América Latina aconteceram na Argentina. O designer Tomás Maldonado escreveu no periódico Boletín o primeiro documento da América Latina no qual a produção industrial foi considerada como uma questão relativa ao design. 0 design se desenvolveu na América do Sul no final dos anos 50 e início dos anos 60. A difusão do design no Brasil começou antes mesmo da sua instituição oficial em nível acadêmico, como mostra Dijon De Moraes parafraseando o designer Gui Bonsiepe: "seria enganoso afirmar que, nos países periféricos, o design tenha começado a existir somente no momento em que foi introduzido o termo [...] Sabe-se ainda que o debate sobre o design não nasceu, como se pode imaginar no interior da indústria, não foi levado adiante pelos representantes das empresas manufatureiras, mas por um grupo de pessoas estranhas à indústria: expoentes da vanguarda das artes visuais (MORAES, 2006, p.30)". 


\section{3}

Surge a televisão em cores sob o tipo comercial (SAMPAIO, 1984, p.194). A primeira experiência dita interativa na TV foi no período entre 1953 e 1957 quando foi ao ar pela rede americana de televisão CBS (Columbia Broadcast System) um programa para crianças chamado Winky Dinky and You. A criança grudava uma folha plástica que vinha em um kit (adesivo eletrostático e crayons), comprado em bancas de revistas, na tela da TV e podia desenhar por cima deste plástico fazendo, por exemplo, o personagem, uma criança chamada Winky Dinky e seu cão Woofer, pular sobre pontes e andar por caminhos diversos de maneira a salvá-lo em situações de aventura. Sem a criança telespectadora o programa não fazia sentido, ou seja, a participação do público de maneira lúdica era o diferencial tornando Winky Dinky and You o primeiro programa participativo da TV (CAREY, 1996, p.4-5).

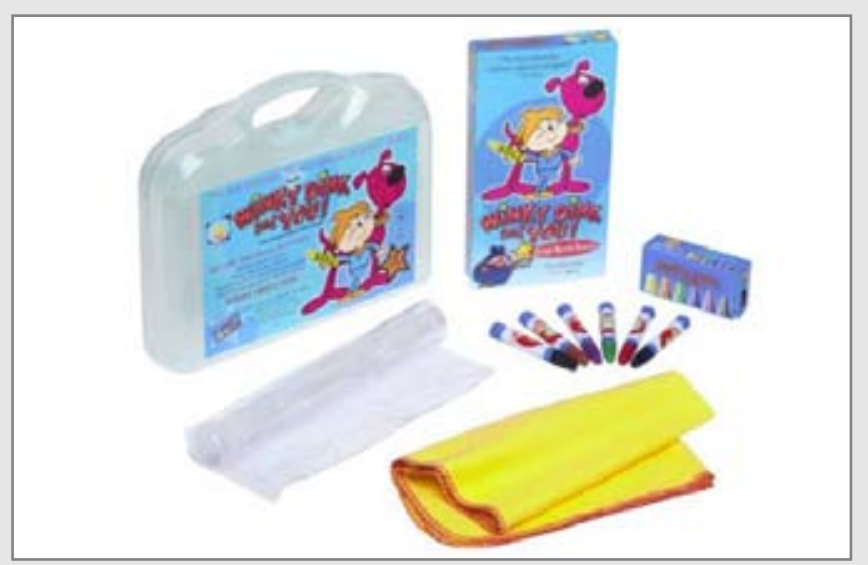

Fig 12. O Winky Dinky Magic Kit é vendido hoje em dia na loja online Amazon. Faz parte do kit uma fita de vídeo cassete (Disponível em: < http://www.amazon.com/exec/obidos/ASIN/B00005U07I/ tvpartycom/ >. Acessado em: 29 de Abr de 2007).

\section{0}

Nos Estados Unidos se introduz o cartão de crédito, que aumenta o crédito a curto prazo para os americanos, aumentando o poder de compra. A produção de automóveis por exemplo, cresceu mais de quatro vezes, refletindo o aumento do consumo (CARDOSO, 2004, p.148-149).

\section{1}

Ocorreu no Instituto de Arte Contemporânea (IAC) do MAM em São Paulo, o primeiro curso de desenho industrial da América Latina, formado nos moldes do Institute of Design de Chicago ${ }^{18}$. O curso, coordenado pela arquiteta Lina Bo Bardi, teve o objetivo de tornar consciente a função social do design e negar a cópia de estilos passados (MORAES, 2006, p.28-29). Neste mesmo ano na Inglaterra aconteceu o Festival of Britain, tributo à história do povo britânico em geral, no qual o papel do design e da arquitetura tiveram uma grande importância ao oferecer um ambiente novo, leve e moderno ao festival. Como exemplo estão as cadeiras Springbok e Antelope do designer Ernest Race (SPARKE et al., 1987, p.156).

18 O Institute of Design de Chicago era a "Nova Bauhaus" e foi composto por designers como Moholy-Nagy, Herbert Bayer, Josef Albers e Walter Peterhans, imigrantes da Bauhaus após seu fechamento político na Alemanha, em 1932 (MORAES, 2006, p.2829). 


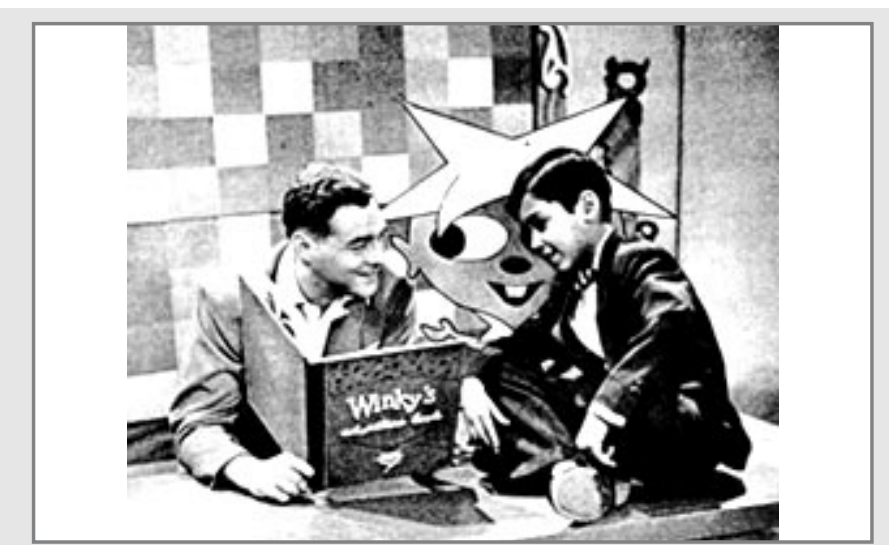

Fig 13. O programa se referia às crianças telespectadoras que tinham a possibilidade de atuar junto ao personagem principal (Disponível em: <http://www.tvparty.com/requested2b.html>. Acessado em 17 Mar 2007).

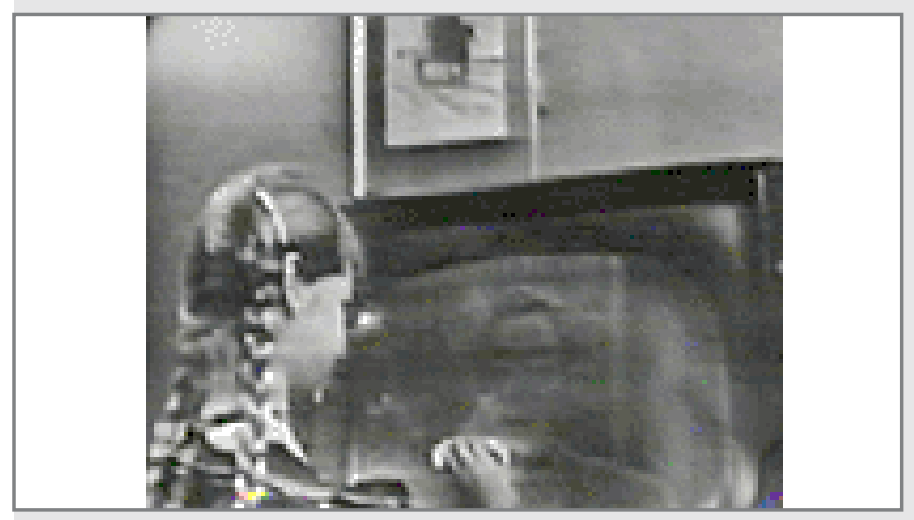

Fig 14. Criança interagindo com o programa (Disponível em: <http: // www.tvparty.com/requested2b.html>. Acessado em 17 Mar 2007).

\section{4}

A emissão de programas em cores começou, sendo adotado também no Japão, Canadá e México (SOUZA, 2002, p.5).

\section{5}

Quase todo o território norte-americano se encontra coberto por transmissões televisivas regulares (PEREIRA, 1999, Disponível em: <http://si.porto.ucp.pt/ internal/mestrado/mest99/Teoria_media/ tv/TEXTOS\%20FINAIS/1_A\%2OInvencao.htm>. Acessado em 3 de Mar de 2007).

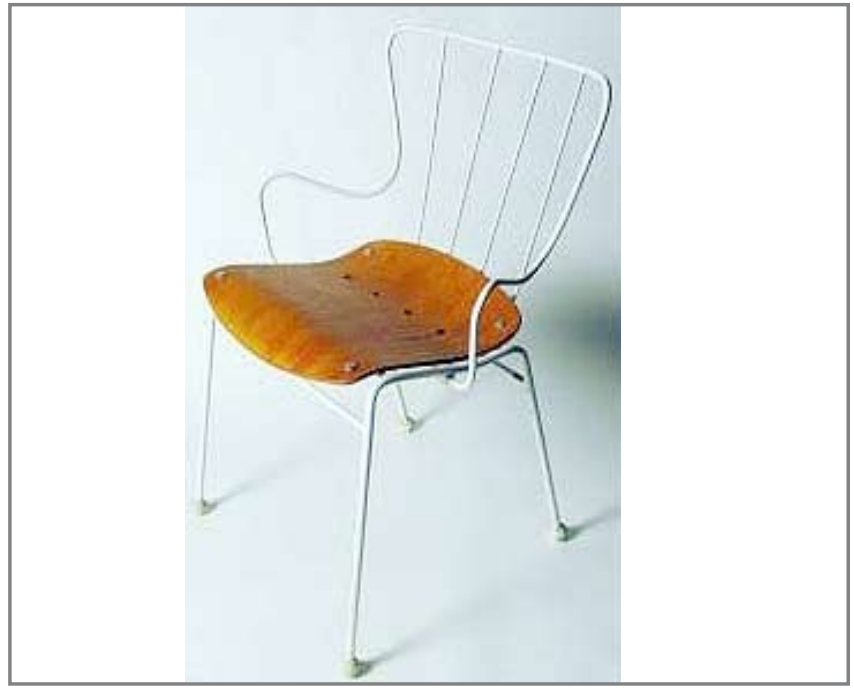

Fig 15. A cadeira Antílope de Ernest Race (1950) foi um dos modelos produzidos para os terraços externos do Festival of Britain (TAMBINI, 1999, p.62).

\section{3}

O designer Charles Eames utilizou uma ampla variedade de desenhos no filme $A$ Communications Primer, de vinte minutos, que explicava teorias da comunicação. Esse trabalho foi precursor de uma série de filmes e apresentações multimídia produzidas para Eames nos vinte anos que se seguiram (HOLIS, 2001, p.129).

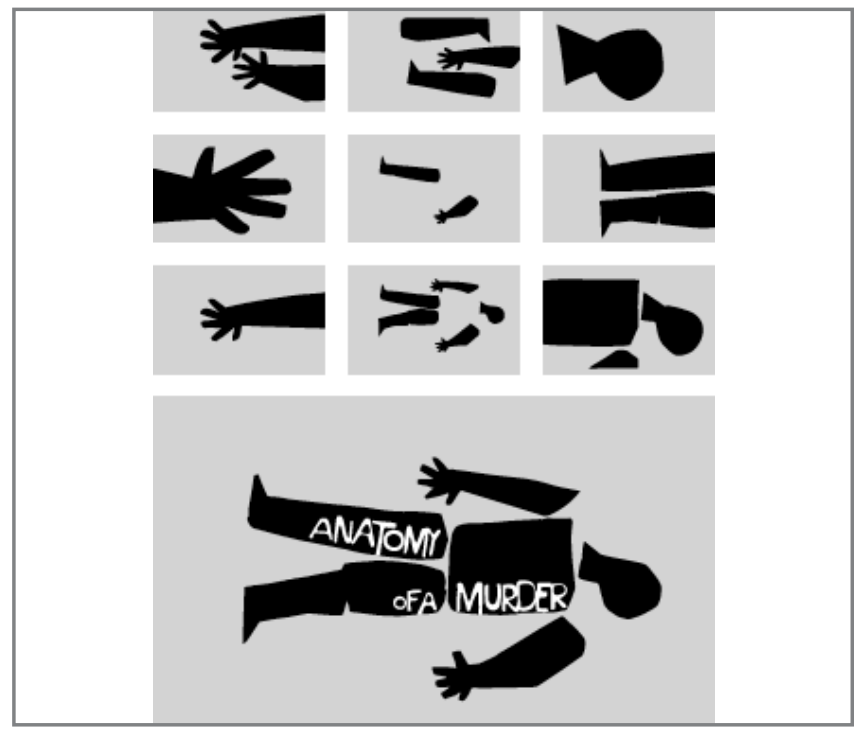

Fig 16. Título gráfico para o filme Anatomy of a Murder, do cineasta Otto Preminger, desing de Saul Bass, 1949 (Disponível em: <http:// www. britannica.com/eb/art-67721?articleTypeld=1 >. Acessado em 17 de Mar de 2007). 
1959

Foi inaugurada no Brasil a TV Excelsior, considerada a primeira emissora a ser administrada nos padrões empresariais de hoje e responsável pela produção da primeira telenovela em capítulos diários e a mais longa da história com 596 capítulos Redenção. A Excelsior foi a primeira emissora a criar vinhetas de passagem nos intervalos comerciais (MATTOS, 2000, p.98).

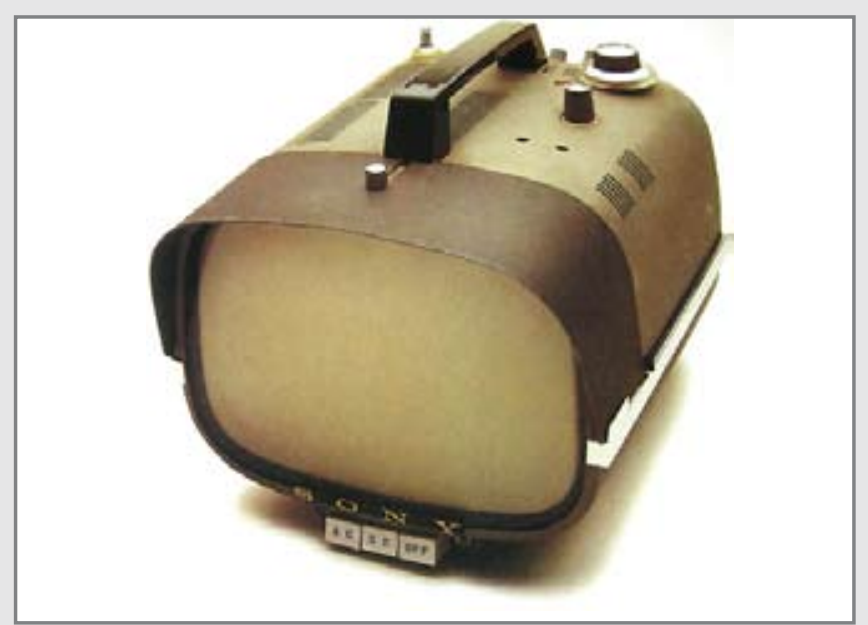

Fig 17. Sony TV8-301, 1959. Com design original e tecnicamente inovadora, a TV8-301 foi a primeira televisão que continha transistores de recepção miniaturizados (TAMBINI, 1999, p.96).

\section{1}

Os Estados Unidos já tinham em serviço 548 estações de TV e 60 milhões de receptores sintonizando-as, suprindo $89 \%$ dos lares americanos (SAMPAIO, 1984, p.194).

\section{4}

Os designers Milton Glaser, Edward Sorel e Seymour Chwast fundaram o Push Pin Studios nos Estados Unidos. O trabalho gráfico destes designers fazia uso eclético de grafismos apropriados de fontes históricas, do chamado design vernacular americano e da cultura popular e consistia em injetar o humor, o acaso e o mau gosto assumido no seio da estética moderna (CARDOSO, 2004, p.179).

\section{6}

O artista e designer Richard Hamilton confeccionou uma colagem a partir de imagens publicitárias e da cultura de massa provenientes de recortes de revistas americanas e criou "Just What Is It That Makes Today's Home So Different, So Appealing?". Hamilton fazia parte de um grupo chamado Independente que se reuniu no Instituro de de Artes Contemporâneas de Londres no início dos anos cinquenta para analisar e criticar os ícones da cultura de massa americana (SPARKE et al., 1987, p.168). 


\section{2}

Foi promulgado pela Lei $n^{\circ} 4.177$ o Código Brasileiro de Telecomunicações. Nesta época já existiam mais de dez emisoras de televisão funcionando no país. Também nesse ano aconteceram as primeiras experiências de TV educativa (MATTOS, 2000, p.99).

\section{3}

Foram feitas demonstrações das possibilidades do videocassete doméstico (SOUZA, 2002, p.5). Foi lançado pela Nasa em 14 de fevereiro o primeiro satélite para cobrir toda a superfície terrestre, o Syncom I (SOUZA, 2002, p.12).

\section{6}

Graças ao satélite Syncom III, lançado em 19 de agosto, foi possível transmitir as imagens de televisão do Japão para a costa oeste dos Estados Unidos durante os Jogos Olímpicos (SOUZA, 2002, p.12).

\section{7}

ATV em cores holandesa foi inaugurada no dia 2 de outubro, por ocasião do encerramento do 15 Salão de rádio e Televisão de Amsterdã. Uma página do Daily Express, de Londres, foi lida em Porto Rico, 20 minutos depois de publicada em Londres. A imagem da página foi transmitida por intermédio do satélite americano Early Bird (SOUZA, 2002, p.14).

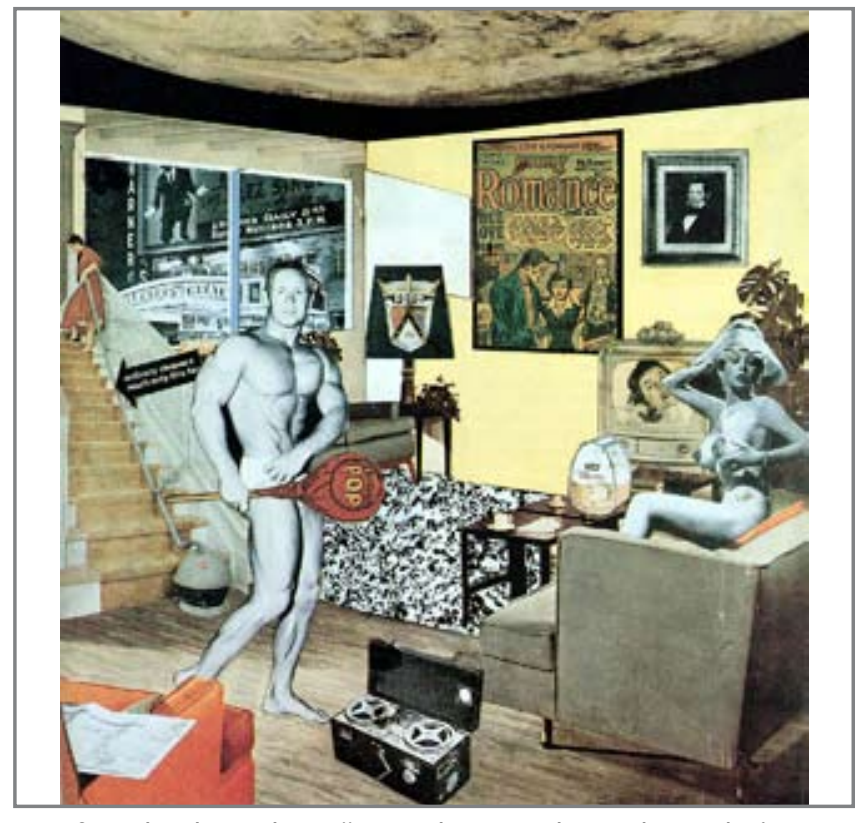

Fig 18. Richard Hamilton, "Just What Is It That Makes Today's Home So Different, So Appealing?", 1956 (SPARKE, et al. 1987, p.166).

\section{7}

0 arquiteto e designer de móveis, Sérgio Rodrigues, projetou a poltrona Mole, fabricada em jacarandá maciço e couro. A poltrona foi uma iniciativa de design nacional não só pelos materiais que utiliza mas também pelo seu jeito despojado, informal e bonachão (CARDOSO, 2004, p.193-194).

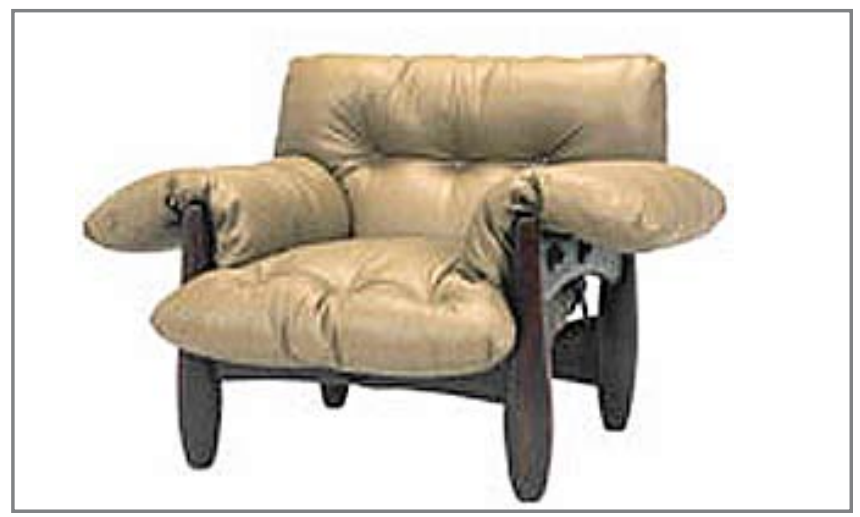

Fig 19. Poltona Mole, Sergio Rodrigues, 1957 (CARDOSO, 2004, p.193). 


\section{8}

No Brasil, o uso do satélite na educação ocorreu quando o Instituto Nacional de Pesquisas Espaciais - INPE elaborou o Projeto SACI (Sistema Avançado de Comunicações Interdisciplinares). Convênio entre o Governo do Estado e a Universidade Federal do Rio Grande do Norte permitiu a produção de programas de rádio e televisão (SOUZA, 2002, p.12).

\section{9}

Em 5 de março chegaram ao Brasil pela primeira vez imagens do Papa Paulo VI, cenas de Roma e Washington através do satélite Intelsat 3 (Internacional Telecommunications Satellite), um engenho avaliado em cinco milhões de dólares, em órbita a 36 mil quilômetros de altura. Os anúncios veiculados pelas estações de televisão durante a transmissão custavam cerca de 750 mil cruzeiros novos (SOUZA, 2002, p.17).

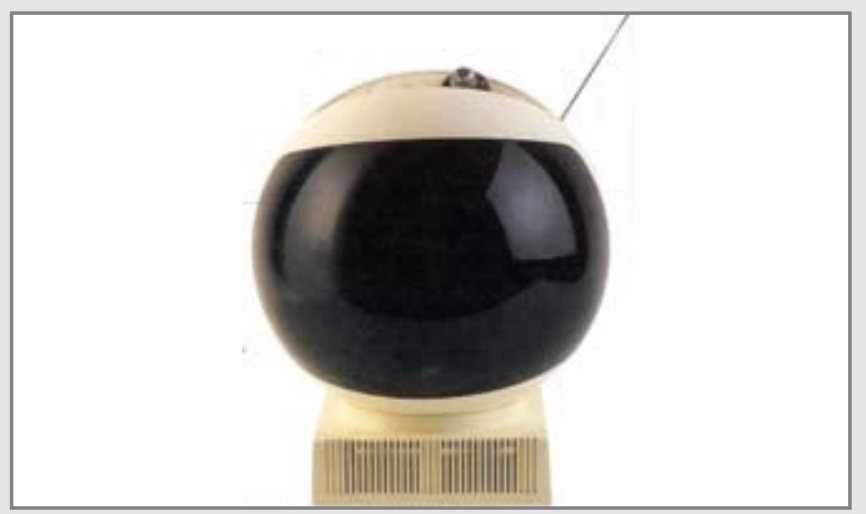

Fig 20. JVC Videosphere (1970) parecia com um capacete de astronauta e refletia o interesse público em viagens ao espaço. Em 1969, 600 milhões de pessoas assistiram pela TV o homem andar na lua (TAMBINI, 1999, p.96).

\section{8}

O Televisor HF1/1958 foi criado pelo designer Herbert Hirche para a firma alemã Braun que o fabricou em 1958 na Alemanha. A firma Braun se destacou no mercado mundial por meio do design de seus produtos, configurados de forma inusitada para a época e baseados na teoria estética da Bauhaus. Estes produtos foram conhecidos como "Boa forma” (LOBACH, 2001, p.168).

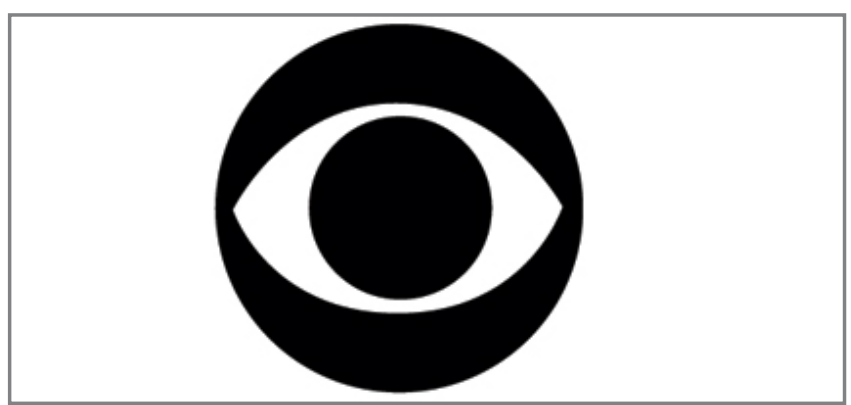

Fig 21. Em 1951, William Golden, diretor de criação da CBS nomeado por Frank Stanton presidente da emissora, cria o logo da CBS que representa o olho do espectador assim como a lente da câmera (LIVINGSTONE, 2003, p.99).

\section{2}

No Brasil, ocorreu na FAU - Faculdade de Arquitetura e Urbanismo da USP - Universidade de São Paulo, a criação de uma sequência no curso de graduação de Arquitetura: a disciplina Desenho Industrial. Essa iniciativa partiu do professor Vilanova Artigas. Desse modo nasceu no Brasil o primeiro curso de design estável e regular em nível superior do país (CARDOSO, 2004, p.170). 


\section{2}

Os japoneses começaram a estudar a TV de tela grande. O projeto denominava-se MUSE (Multiple Subnyquist Sampling Encoding) e previa um sistema de 1125 linhas por quadro (SOUZA, 2002, p. 11).

Vinte anos após a primeira experiência de TVI com o programa Winky Dinky and You, foi ao ar pela rede inglesa de televisão, BBC de Londres, o que foi considerado o primeiro teletexto do mundo: 0 CEEFAX ${ }^{7}$, ou "see facts". Um serviço desenvolvido por engenheiros, que consistia em textos informativos transmitidos pela televisão. 0 teletexto permite que dados digitais sejam transmitidos por sinal analógico. 0 telespectador podia acessar rapidamente os serviços de classificados, resultados de jogos e loterias, resumos de filmes e informações sobre condições climáticas. O CEEFAX abriu novas perspectivas em relação à comunicação mercadológica, pois, o serviço de teletexto além de ser rapidamente acessado, não gera custos de chamadas telefônicas ou de acesso à Internet (Disponível em: <http://teletext. mb21.co.uk/gallery/ceefax/main1.shtml>. Acessado em 17 de Mar de 2007).

7 O CEEFAX é utilizado até hoje, mas está fadado a não permanecer no formato atual, pois com o advento da TV Digital o teletexto será transmitido por sinal digital.

\section{3}

AESDI - Escola Superior de Desenho Industrial, iniciou suas atividades no Brasil tal qual a Bauhaus e Ulm, como uma escola de natureza experimental. AESDI era percebida como uma transplantação do modelo Ulminiano para o Brasil (CARDOSO, 2004, p.172-173).

Foi fundada em São Paulo a Associação Brasileira de Desenho Industrial (ABDI) que contava com a participação de nomes fundamentais do design brasileiro. Esta foi a primeira organização do país que possibilitou a atuação do designer em um plano maior, ou seja, que tornou possível ao designer projetar não só objetos materiais que definem um contexto cultural mas também a própria identidade que se constrói a partir deles (CARDOSO, 2004, p.197).

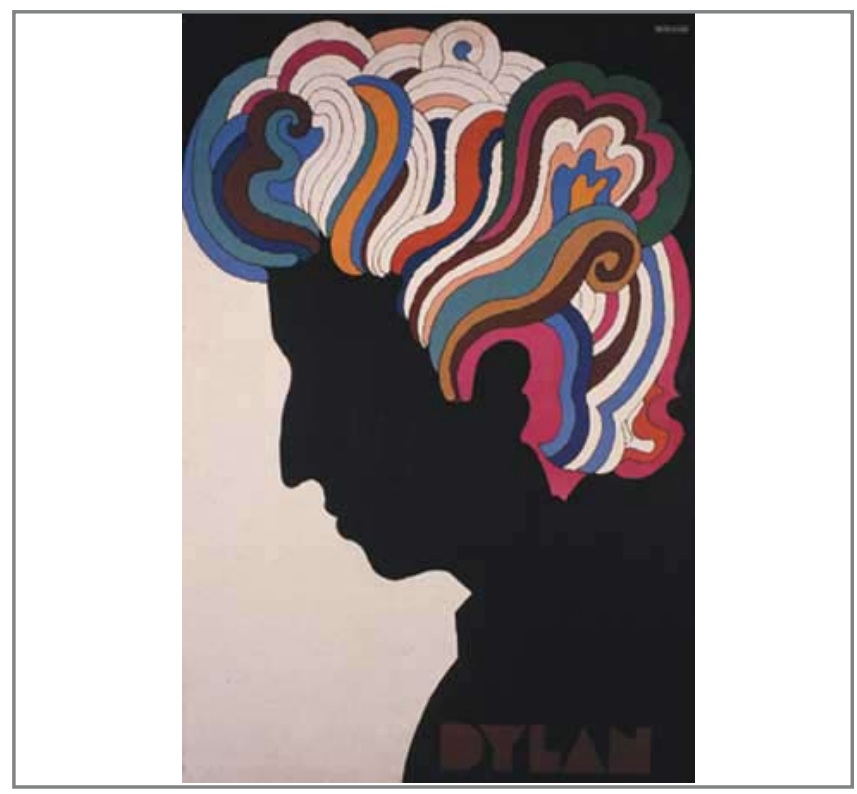

Fig 22. A consciência jovem na era nuclear manifestou seu protesto através das canções de Bob Dylan. Poster para o músico Bob Dylan, desenvolvido pelo designer americano Milton Glaser, 1967 (TAMBINI, 1999, p.36). 


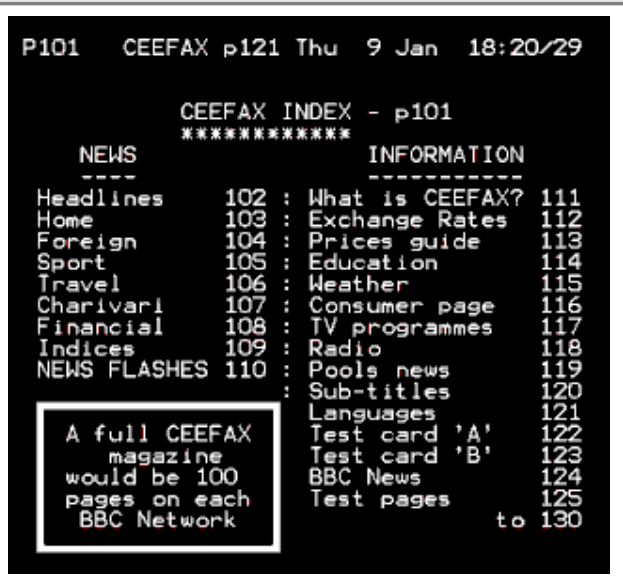

Fig 23. Página do CEEFAX de janeiro de 1975 quando o serviço ainda era experimental. (Disponível em: http://teletext.mb21.co.uk/ gallery/ceefax/main1.shtml. Acessado em 17 Mar 2007).

\section{3}

A Internet foi inicialmente desenvolvida pelo americano Vincent Cerf, um cientista em computação que trabalhava em projeto financiado pela Agência de Projetos de Pesquisa Avançados em Defesa - ARPA, do Departamento de Defesa dos Estados Unidos. No início denominou-se ARPANet, ligando redes de computadores em várias universidades e laboratórios de pesquisas dos Estados Unidos (SOUZA, 2002, p.14).

\section{4}

A Springer-Admiral lançou o super-solarcolor, primeiro receptor de televisão para imagens em cores produzido no Brasil, com tela de 13 polegadas. O lançamento do produto aproveitava a Copa do Mundo e teve Zagalo, treinador da seleção brasileira, como garoto propaganda (SOUZA, 2002, p.16).

\section{8}

A Escola de Ulm foi fechada na Alemanha. Com isso a ESDI, no Brasil, perdeu o seu modelo a ser seguido e, então, tornou-se claro que a filosofia de design alemã não funcionava no Brasil e não iria funcionar no futuro. Neste mesmo ano, na Bienal Internacional de Desenho Industrial no Rio de Janeiro, estudantes de design denunciavam por meio de uma instalação contendo objetos de uso cotidiano do brasileiro, que no Brasil havia uma escola de design, alguns designers mas nenhum design (BOMFIM, 1995, p.126-127).

\section{9}

Por causa do ativo envolvimento do design com 0 processo produtivo e a atitude conscienciosa dos designers em relação as questões ecológicas, o ICSID (International Council of Societies of Industrial Design) aconselhou os designers a darem prioridade a qualidade de vida sobre a quantidade de produção. (CARDOSO, 2004, p.215). 
1977

O QUBE (Warner Amex's Qube system), nos EUA em Columbus, Ohio, foi um dos maiores testes comerciais de TV Interativa a cabo que oferecia canais especializados, por exemplo, o canal infantil Pinwheel, que inspirou o Nickelodeon e o Sign On Sound ${ }^{8}$. O usuário podia votar em suas músicas e vídeos favoritos além de jogar através de um controle remoto especial com cinco teclas extras que permitia o acesso ao conteúdo (CAREY, 1996, p.5-6).

\section{8}

Dois estudantes da Universidade de Chicago, Ward Christensen e Randy Suess, inventaram o modem para evitar uma longa viagem entre os lugares em que moravam no inverno de Chicago, tentaram encontrar um sistema para transferir programas de um microcomputador para outro via telefone (SANTAELLA, 2004, p.84).

\section{2}

A televisão com tela de cristal líquido foi desenvolvida e dois anos depois surgiu o som estéreo na TV (SOUZA, 2002, p.5).

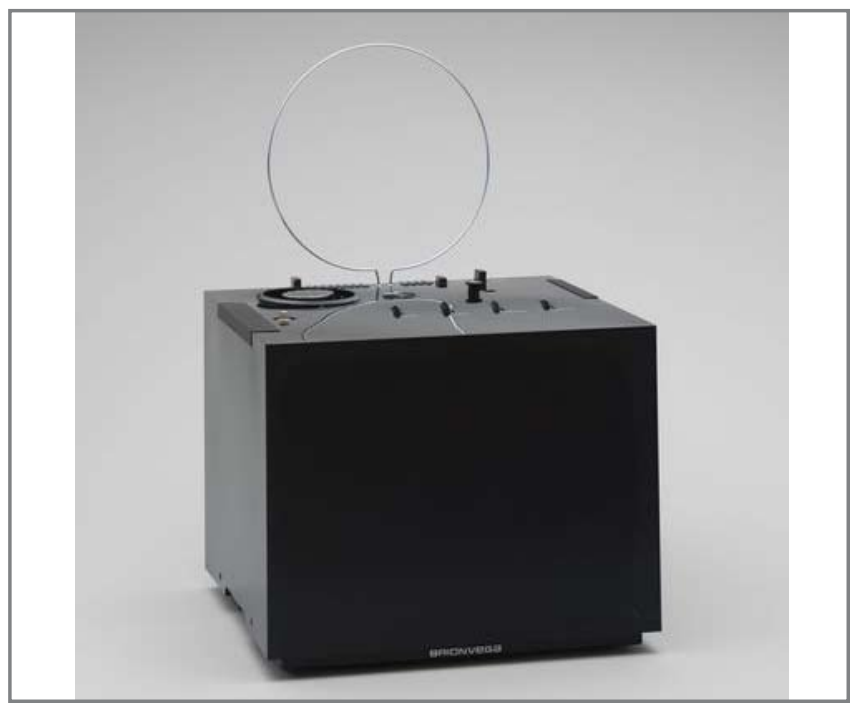

Fig 24. Televisão Black 12 criada pelos designers Marco Zanuso e Richard Sapper para Briovenga em 1969. Famosa por ser uma caixa preta sofisticada, a TV Black continha a tela da TV que ficava imperceptível quando a TV estava desligada (SPARKE, et al. 1986, p.208). (Disponível em: <http: / / www.moma.org/images/collection/ FullSizes/13463003.jpg>. Acessado em 17 de Mar de 2007).

\section{1}

O designer Victor Papanek lança o livro Design for the real world, que marcou época ao ter lançado a crítica sobre a visão tradicional do design face aos desafios humanos e ambientais do mundo moderno (CARDOSO, 2004, p.194).

\section{8}

Formou-se a Associação Profissional de Desenhistas Industriais de Nível superior (APINS). Esta Associação é dissidente da primeira, a ABDI (CARDOSO, 2004, p.198). 


\section{3}

O set-top box decoder analógico de apenas uma via começou a aparecer nos lares americanos. Hoje 90 milhões de lares têm não apenas um, mas alguns set-top boxes analógicos e/ou estão atualizando-os pelos digitais. (Disponível em: <http://www.itvt. com/etvwhitepaper-5.html>. Acessado em: 29 de Abr de 2007).

\section{4}

Uma nova lei chamada 1984 Cable Act acelerou a penetração de TVs a cabo nos EUA. Os lares americanos chegaram a ter 50 milhões de TVs a cabo ao final da década de 80 (LU, 2005, p.32).

\section{1}

Surgimento da MTV (Music Television), nos Estados Unidos. A MTV é um programa de televisão para jovens que apresenta basicamente vídeoclipes. A MTV trouxe para o público jovem uma linguagem de vídeo que apresenta cortes rápidos e sons eletrônicos intensos, preparando a sensibilidade para o mundo digital (SANTAELLA, 2004, p.96-97).

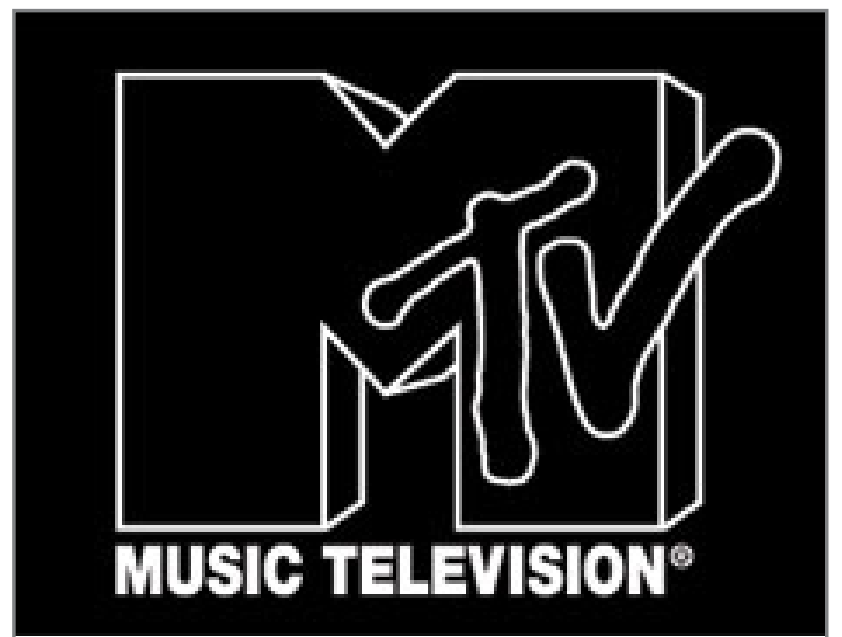

Fig 25. Logomarca da MTV (MTV, 2007. Disponível em:<http://www. mtv.co.uk>. Acessado em 28 de Abr de 2007 ). 


\section{5}

O QUBE foi descontinuado, principalmente porque o programa era muito caro. Custava aproximadamente US\$ 200,00 por cada terminal instalado nas residências e os consumidores não podiam pagar sem a ajuda do governo norte-americano. 0 custo benefício do QUBE não era factível do ponto de vista empresarial. A verba destinada a estes testes era muito inferior àquela destinada à programação de TV analógica e foi, portanto, impossível competir com ela. Além disso, todos os equipamentos técnicos eram apenas protótipos e ainda apresentavam muitos defeitos. Todos estes fatores contribuíram para que o QUBE não surtisse o efeito de mercado desejado, especialmente numa época em que as pessoas ignoravam a interatividade (CAREY, 1996, p. 6-7).

\section{2}

O faqueiro DRY foi criado por um dos mais importantes designers industriais do século vinte: Achille Castiglini (1918 - 2002). E também foi a primeira escala de facas produzida pelo designer italiano Alberto Alessi. Sua forma inovadora contém qualidades de manuseio impressionantes. $\mathrm{Na}$ Finlândia o faquerio DRY é um dos produtos de maior venda, com 51 peças diferentes que executam seu trabalho com excelência. Por causa do seu design plano, simples e útil, o faqueiro foi relativamente barato de se produzir e, portanto, pôde-se vendêlo a preços acessíveis. Este pensamento de Castiglioni tornou-se muito admirado e se difundidiu entre os designers. Castiglioni, em parceria com seus dois irmãos, produziu mais de 150 produtos criando um duradouro relacionamento com manufatureiros italianos como Flos em luminárias, Zannota em móveis e Alessi em produtos para casa. Seu lema era: "Comece de um esboço. Vá até ao senso comum. Saiba seus objetivos e significados" (SELLERS org., 2007). 
1987

Foram feitas demonstrações com a Televisão de Alta Definição. A Compagnie Française de Television desenvolveu o sistema SECAM (Sequentiel en Couleurs a Memoire). Na Alemanha, o doutor Walter Bruch e técnicos da Telefunken modificaram o sistema norteamericano, tornando-o menos sensível às distorções na matiz das cores, uma de suas limitações, e criaram o sistema NTSC com Linhas de Fase Alternada (Phase Alternated Line), ou PAL (SOUZA, 2002, p.5).

\section{8}

Teve início no Brasil o serviço de TV por assinatura através da Key TV que transmitia corrida de cavalos via satélite para alguns assinantes (SOUZA, 2002, p.12).

\section{1}

Entrou no ar a Globosat, que captava programas internacionais para depois selecioná-los e editá-los. O sinal era codificado e depois enviado ao satélite. Para captar os programas, o telespectador da Globosat deveria possuir um decodificador que "desembaralhava" os sinais (SOUZA, 2002, p.13).
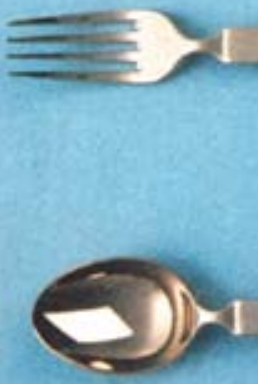

Fig 26. Faqueiro DRY. Fabricado por Alessi, Italia. Design de Achille Castiglioni. Coleção da Fundação Conran (SELLERS org., 2007).

\section{3}

Inspirada nos barcos que navegam pelo Rio Reno, a chaleira projetada por Richard Sapper foi produzida em aço inoxidável e comporta até 2 litros de água. Apropriada para o fogão à gás, elétrico ou cerâmico, ao ferver a água o vapor faz com que ela cante e assobie harmonicamente através dos dois bicos de bronze. Sapper expressava sua abordagem metodológica ao design da seguinte maneira: dando à forma um significado. E, assim, se distanciava do tradicional funcionalismo germânico que pregava que a forma tinha que acompanhar a função. Por meio da melodia que a chaleira emitia, Sapper delegava um fator especial e emotivo ao seu produto, que visivelmente contém alta tecnologia (SELLERS org., 2007). 


\section{2}

Nos Estados Unidos, uma pequena empresa chamada Telemorphix criou um programa ao vivo de uma hora de audiência chamado "21st century Vaudeville". Este programa ia ao ar uma vez por semana em um canal de TV a cabo da Viacom em São Francisco e se tornou um sucesso. 0 apresentador era um avatar chamado Jack, os telespectadores telefonavam para o programa via um número 0800, escolhiam um motivo para representá-los (Punk, Fork, StickMan, etc.) e apresentavam seus clipes musicais na TV através do Jack. A voz do telespectador era captada e o Jack a reproduzia movimentando a boca (CAREY, 1996, p.15-16).

\section{3}

Também nos Estados Unidos, desenvolvedores criaram uma grande aliança estratégica para a criação de padrões para transmissão de sinais de televisão digital. Isso representou um compromisso técnico entre as necessidades de duas indústrias: a de TV e a de Internet. Em 1982 foram finalizados trabalhos que concluíram os protocolos fundamentais que governavam o funcionamento das redes. O nome "Internet" deriva do nome destes protocolos. Nasce em 1993 a World Wide Web, rapidamente popularizada no mundo (HARRIES, 2002, p.10, p.40).

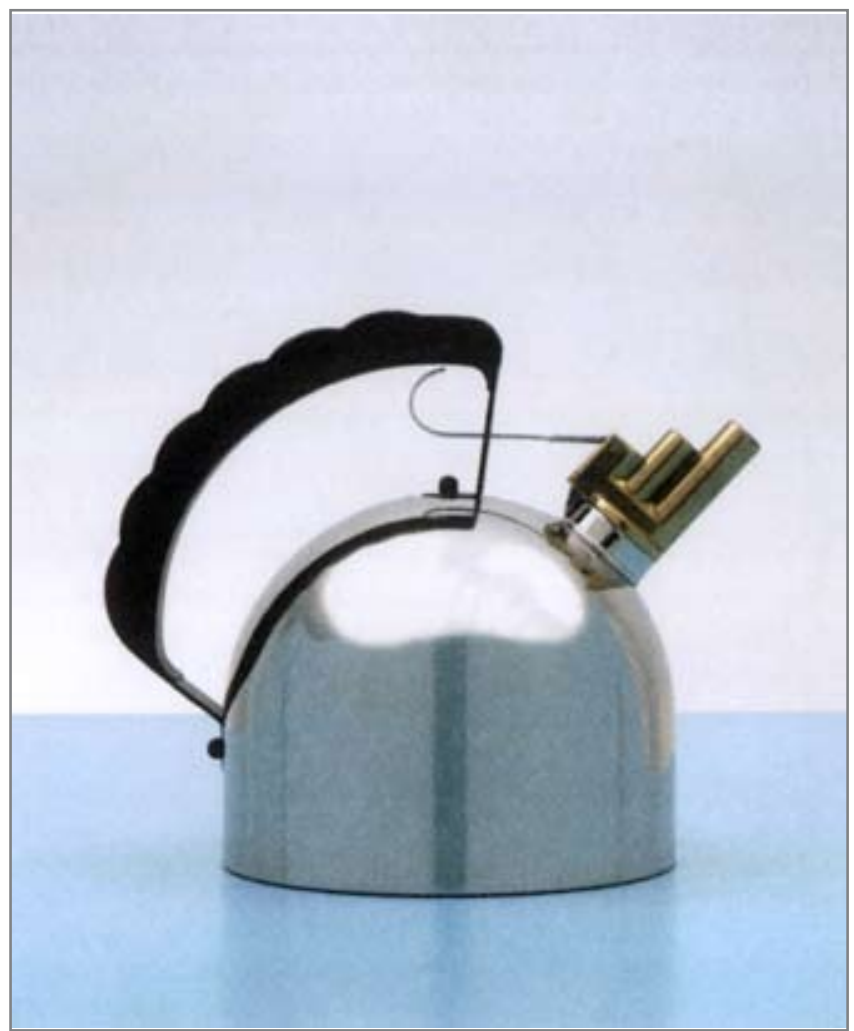

Fig 27. Chaleira. Design de Richard Sapper. Fabricado por Alessi, Italia. Coleção do Design Museum (SELLERS org., 2007).

\section{4}

No Brasil, devido a uma política interna que não investia na industrialização do país, alguns designers brasileiros buscaram trabalhar no mercado mundial e encontraram soluções criativas para se desenvolverem internacionalmente, como exemplo a linha de tesouras Ponto Vermelho da Hércules/ Mundial que se tornou sucesso no mundo, criada pelo designer brasileiro José Carlos Bornancini (CARDOSO, 2004, p.191). 


\section{4}

Devido às tendências mercadológicas indicadas em pesquisas americanas, a empresa Time Warner decidiu investir em serviços de TV Interativa. O investimento financeiro compreendia aproximadamente cinco bilhões de dólares a serem gastos durante os cinco anos conseguintes. O serviço se chamava Full Service Network ou FSN e oferecia vídeos on demand, compras e video games para 4000 lares em Orlando, na Flórida. Contava com parceiroscomoa empresa de telecomunicações americana AT\&T e Silicon Graphics e teve sucesso em campanhas publicitárias. Ao longo do tempo os usuários começaram a criticar a capacidade técnica e o modelo de negócios do FSN, o que motivou a sua suspensão em 1997. Novamente, assim com o QUBE, a relação custo benefício foi o principal fator dessa descontinuidade, porém, o advento dos PCs (Personal computers) e o boom da Internet também podem ser considerados como um segundo fator. Os consumidores estavam satisfeitos usando seus PCs ao invés da TVI. As experiências que se sucederam, a partir de então, serviram como plataforma para o que está sendo desenvolvido hoje no mundo, em termos de TVI (CAREY, 1996, p.15-16).

\section{6}

Alan Fletcher (1931-2006) foi um dos mais inspiradores designers gráficos entre os britânicos nos últimos 25 anos. O Lloyd's of London foi construido entre 1979 e 1986 pelo arquiteto Richard Rogers. O projeto, ganhador de prêmios em arquitetura, celebra o modernismo e a estética da engenharia. 0 projeto gráfico colorido de Fletcher deu vida ao prédio de vidro e aço, onde os visitantes podiam obter a informação através da arquitetura (SELLERS org., 2007).

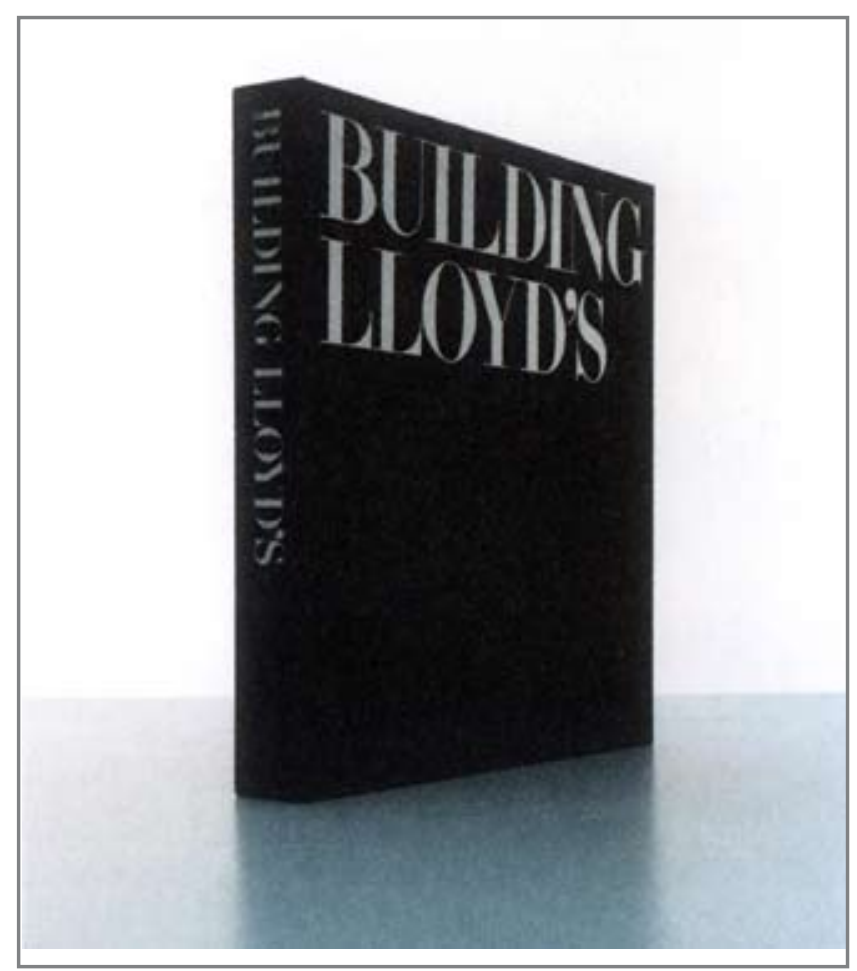

Fig 28. Identidade gráfica do Lloyd's of London. Design de Alan Fletcher. Coleção do Design Museum (SELLERS org., 2007). 
1995

A empresa americana Intel lançou um produto chamado Intercast no mercado. Uma placa de computador que era instalada em um PC e permitia que o sinal de TV fosse visto no computador. Os colaboradores que geravam conteúdo incluiam a CNN, a CNBC, a Lifetime, oQVC, oM2 e o Weather Channel.ANBC chegou a transmitir uma versão especial dos Jogos Olímpicos de Verão de 1996. Infelizmente, a Intercast encontrou poucos compradores de placas de computador pois eram: a) ainda um conceito muito novo, b) difícil de instalar no PC, e c) não havia conteúdo suficiente oferecido para captar usuários interessados. (Disponível em: <http://www.itvt.com/ etvwhitepaper-5.html> Acessado em 29 de Abr de 2007).

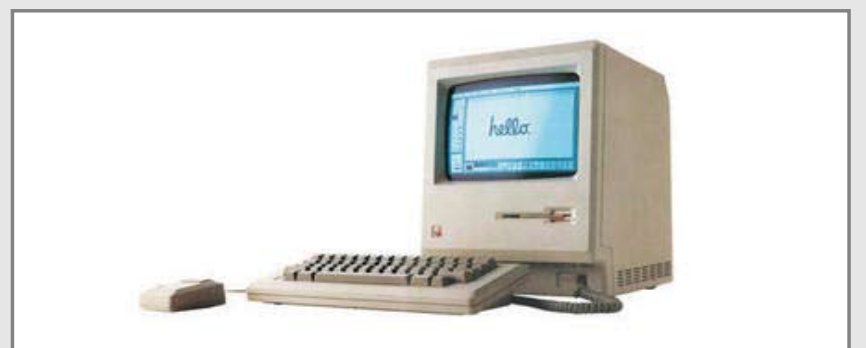

Fig 29. Apple Macintosh, criado pela frogdesign para a Apple Computer e lançado em 1984. Ficou famoso pela alta definição dos gráficos na tela e por sua utilização amigável (TAMBINI, 1996, p.344.).

\section{7}

O design racional do designer italiano Enzo Mari (1932 - ) que defende que quando se fala de design, o real significado desta palavra é o bom projeto, apresenta produtos de massa belos de se ver, com qualidades táteis e que desempenham seu papel com excelência. A forma do cortador de queijo tem um apelo minimalista e permite uma pitada de poesia que emerge da evocação de ser utilizado. Atualmente Mari dedica-se tanto à pesquisa quanto à prática do design (SELLERS org., 2007).

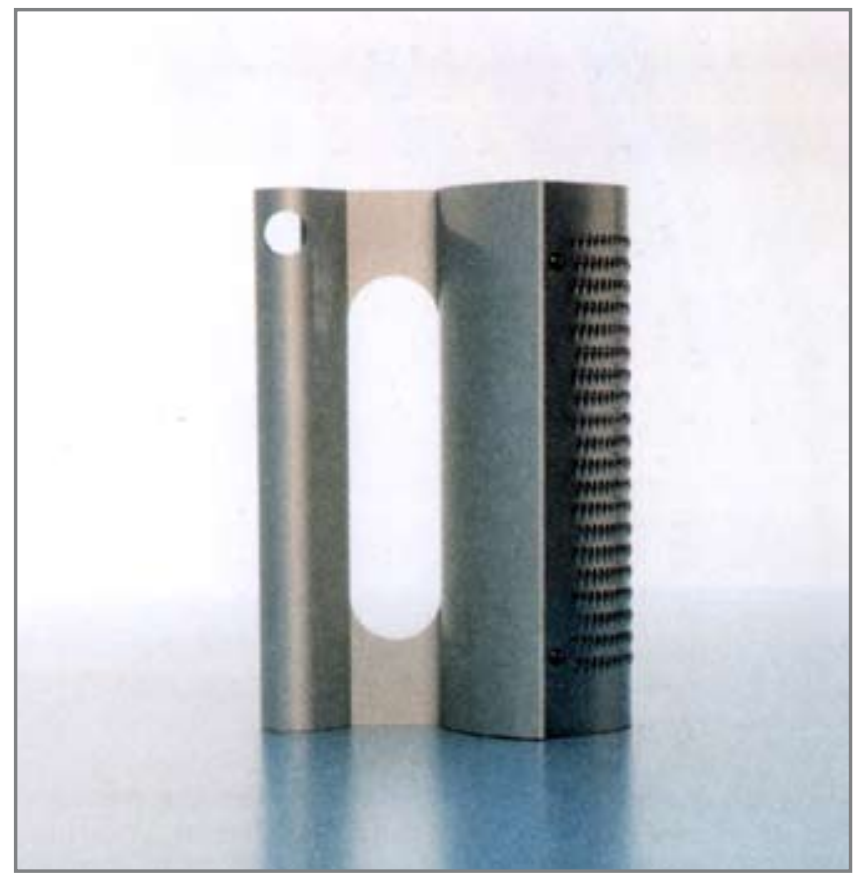

Fig 30. Cortador de queijo. Design de Enzo Mari. Fabricado por Zani\&Zani, Italia. Coleção do Design Museum (SELLERS org., 2007). 
1996

Apenas dois anos depois do FSN, começaram na Europa as primeiras experiências em TVI. Após observar todos os esforços norteamericanos, os europeus orientaram as suas experiências de forma direcionada em um projeto viável financeiramente, principalmente oferecendo vídeo on demand. ABritish Telecommunications conduziu testes em dois mil lares nas cidades de Ipswich e Colchester durante 1995 e 1996, oferecendo filmes com vídeo on demand, shopping, banco eletrônico e jogos. Os resultados foram positivos e os levou a conduzir serviços de TVI em Londres, utilizando a operadora de canais a cabo da British Telecommunications (CAREY, 1996, p.15-16).

\section{8}

Ao combinar formas divertidas e experimentos com tecnologias avançadas, Ron Arad (1951-) surge com um dos designers mais influentes dos nossos tempos. Nascido em Tel Aviv, mudou-se para Londres em 1973 para estudar arquitetura e se firmou nos anos 80 como autodidata e designer especialista em móveis/ escultura. A Big Easy, feita de folhas de metal polido, é uma poltona inspirada nos anos $30 \mathrm{e}$ necessita de muito trabalho técnico para ser produzida, o que implica em um alto custo de mercado. Ela é um dos exemplos do trabalho de Arad que têm com característica um forte laço com a arte. A Big Easy representa um forte contraste para a produção industrial que, paradoxalmente, interessou muito a fabricantes internacionais. Eles se uniram e produziram uma série destas poltronas em colaboração com grandes companias estrangeiras (SELLERS org., 2007).

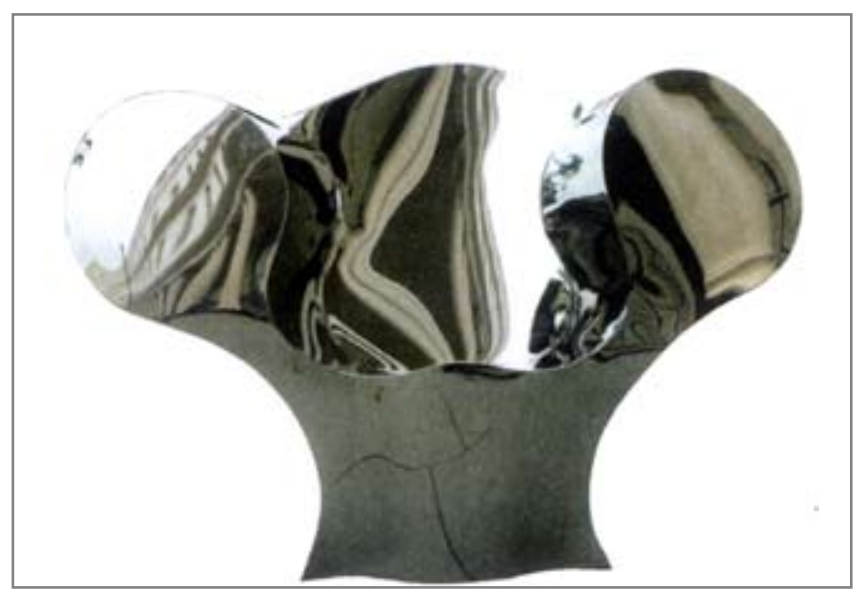

Fig 31. Poltrona Big Easy. Design de Ron Arad (SELLERS org., 2007). 


\section{6}

Ao mesmo tempo, começaram também a aparecer os comerciais publicitários interativos como o da Kellog's com a marca Frosties, seguido da marca de salgadinhos Walker Crispies onde o telespectador podia jogar e participar de questionários interativos sobre assuntos variados garantindo 0 entretenimento na TV. Nesse aspecto, o mais rápido desenvolvimento, depois da Inglaterra, foi o da França. Os franceses aguardaram toda a Europa desenvolver os testes em TVI, até que a TPS (Television per satellite) lançou seus serviços interativos através de canal digital. A maioria deles foi ao ar sem suportes de comunicação ou manuais de instruções para o usuário, descobrindo-se sem auxílios externos, como lidar com a interatividade na TV. Alguns canais, como o que disponibiliza condições climáticas, obtiveram os maiores acessos (CAREY, 1996, p.15-16).

Também em outubro de 1996, a WebTV se estabelece como um importante líder de mercado quando lança um set-top box com serviços de Internet. Chamou a atenção do consumidor e da mídia pois podia ser adquirido por baixos custos e continha grande acessibilidade (Disponível em: < http: / / www. itvt.com/etvwhitepaper-5.html Acessado em 29 de Abr de 2007).

\section{9}

Foi criada no Brasil a ADG - Associação de Designers Gráficos (<http://www.adg.org. $\mathrm{br} />$ ) (CARDOSO, 2004, p.198).

\section{1}

Colors é uma revista sobre diversidade. Apresenta o mundo real por meio de fotos e objetos incríveis. A direção criativa é de Oliviero Toscani e Tibor Kalman e denota uma revista capaz de surpreender sempre. Colors apresenta o mundo real sem qualquer cosmética, trata de problemas do mundo como racismo e AIDS. O conteúdo editorial com ênfase política rompeu barreiras e colocou o design em uma posição onde as palavras são secundárias às imagens (SELLERS org., 2007).

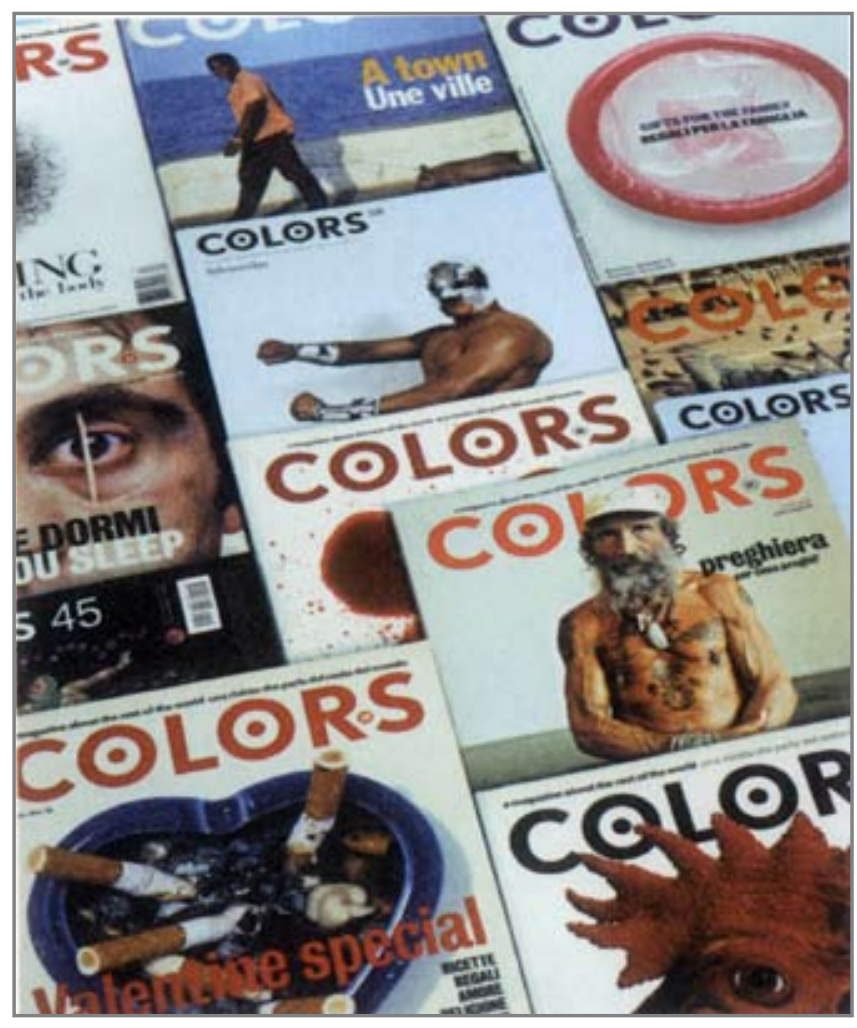

Fig 32. Revista Colors. Lançada pela Fabrica, Benetton, Italia (SELLERS org., 2007). 
1997

ATV paga no Brasil registrava mais de cem mil assinantes com tendência a um vertiginoso crescimento. A televisão a cabo permite uma desmassificação da comunicação, porque permite ao assinante escolher o canal de seu agrado e o programa favorito num universo bem maior do que a televisão convencional (SOUZA, 2002, p.13).

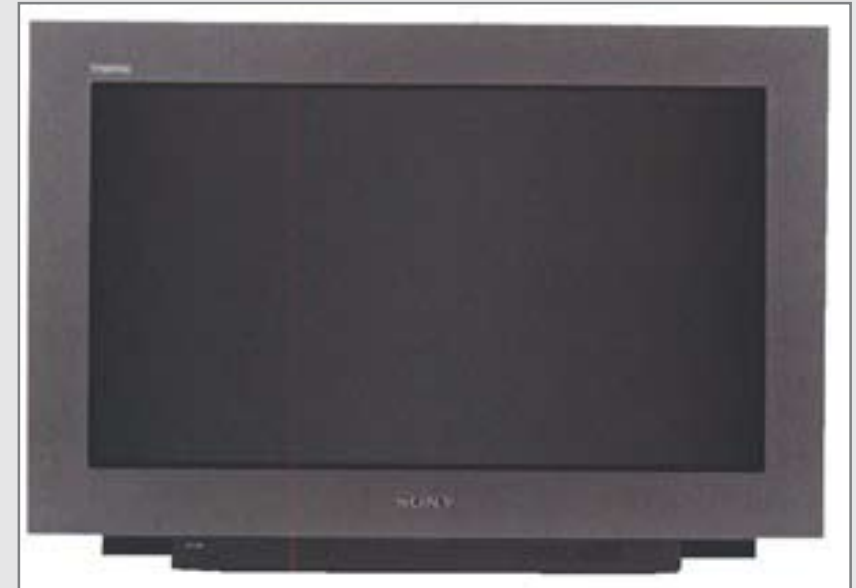

Fig 33. TV Sony KV-32 FD 1, 1998.

Milhões de dolares são investidos para o desenvolvimento da TV com melhor qualidade, design e preço. Entre os anos 80 e 90 houve grandes esforços e avanços tecnológicos nesta área, inclusive o desenvolvimento da TV de tela plana e wide screen, como este modelo Sony Trinitron ${ }^{\circledR}$ de tela plana (TAMBINI, 1999, p.97).

\section{0}

Após testes da Anatel (Agência Nacional de Telecomunicações), SET (Sociedade Brasileira de Engenharia de Televisão) e Abert (Associação Brasileira de Emissoras de Rádio e Televisão), finalizados em 2000, o governo brasileiro se reservou o direito de decidir como será a transição para o modelo digital e criou grupos de trabalho que vão decidir o futuro da TV no país (BECKER; MONTEZ, 2005, p.74).

\section{4}

Foi criada no Brasil a AEnD-BR - Associação de Ensino do Design no Brasil (<http: //www. pacc.ufrj.br/subdesign/aend/>), responsável pela realização bienal do congresso P\&D Design (CARDOSO, 2004, p.198).

O design da TV Jim Nature do designer Philip Stark prova que mesmo um material banal, tradicionalmente escondido dentro de portas de armários pode ter um potente impacto pelo seu apelo estético. 0 trabalho de Stark encoraja o consumidor a re-avaliar os produtos que escolhem para estarem em seu entorno (SELLERS org., 2007).

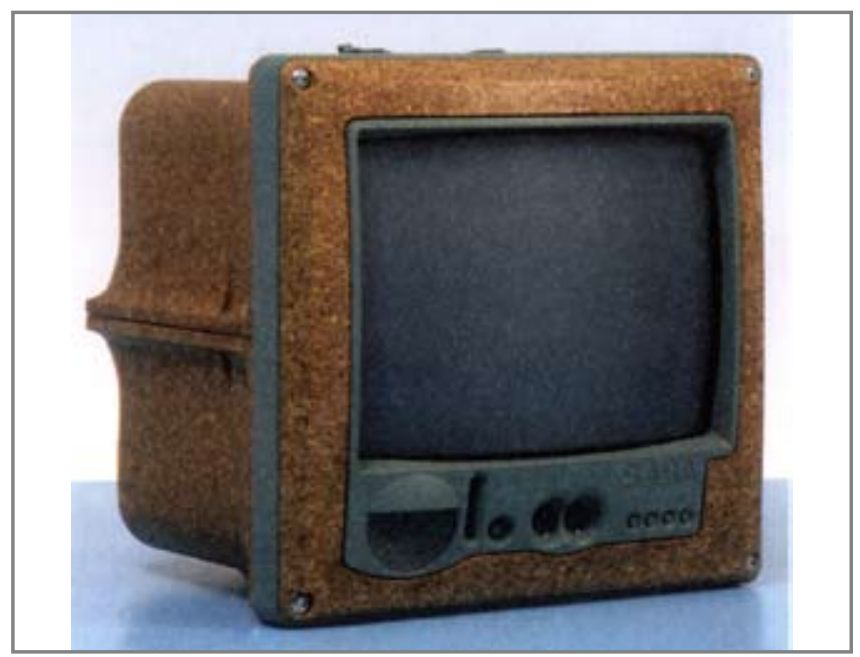

Fig 34. TV Jim Nature (1994). Design de Phillip Stark. Fabricado por Thomson Consumer Eletronics, Saba, França. Coleção do Design Museum (SELLERS org., 2007). 


\section{9}

Surgiu no mercado o TiVo e a ReplayTV que modificou o modo como o usuário assistia a TV ao oferecer a capacidade de gravar o programa desejado (Disponível em: < http: / / www.itvt.com/ etvwhitepaper-5.html> Acessado em 29 de Abr de 2007).

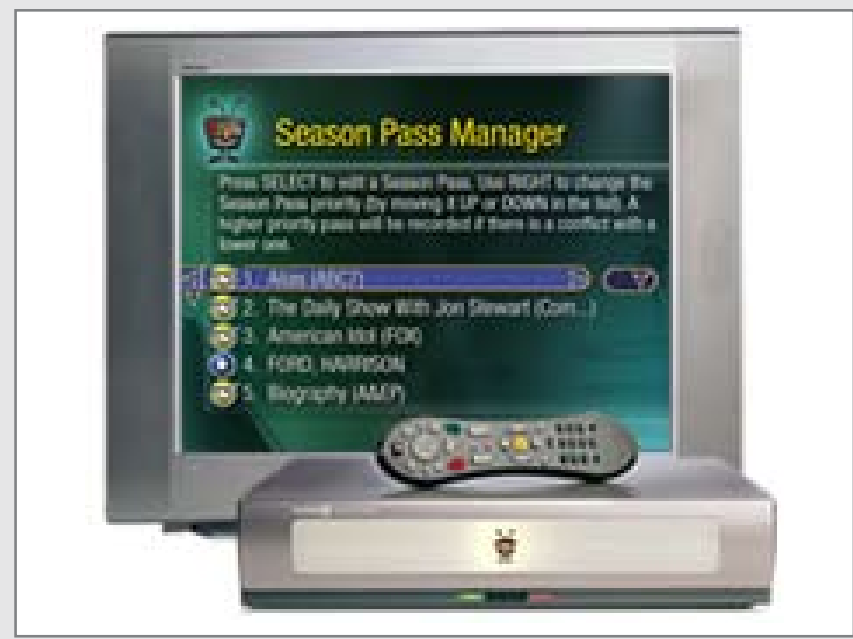

Fig 35. Tivo. (Disponível em: <http://www.tivo.com/1.2.asp>. Acessado em 29 de Abr de 2007).

\section{1}

A distribuição de TVI no mundo: iniciaram-se programas de TVI para qualquer sistema de MSO $^{9}$ (Multiple System Operator) e de DBS ${ }^{10}$ (Direct Broadcast Satellite). O sinal estava disponível para mais de 6 milhões de lares. A OpenTV, Liberate, Canal+, e WorldGate fizeram importantes alianças estratégicas e mais de 20 milhões de lares obtiveram set-top boxes capazes de algum tipo de interatividade (LU, 2005, p.32).

9 Termo usado por operadoras de TV a cabo que detêm um número variado de redes e serviços.

10 O sistema DBS contém satélites poderosos o bastante para transmitir o sinal direto para uma banda receptora (antena) média ou pequena. Este sistema não requer um agente intermediário para distribuição e recepção do seu sinal, transmite direto para o usuário final.

\section{6}

Foi criado no Brasil o Programa Brasileiro de Design (PBD), fato que afirma a crença da indústria no design como elemento estratégico capaz de agregar valor à produção industrial nacional (CARDOSO, 2004, p.190).

\section{8}

O computador pessoal iMac da Apple, foi lançado em 1998 nos Estados Unidos e logo se tornou um ícone mundial de design. Logo após seu lançamento, o iMac ganhou cores para que fosse um produto de fato percebido não só por suas qualidades técnicas mas também pela beleza do seu design (TAMBINI, 1996, p.148-349).

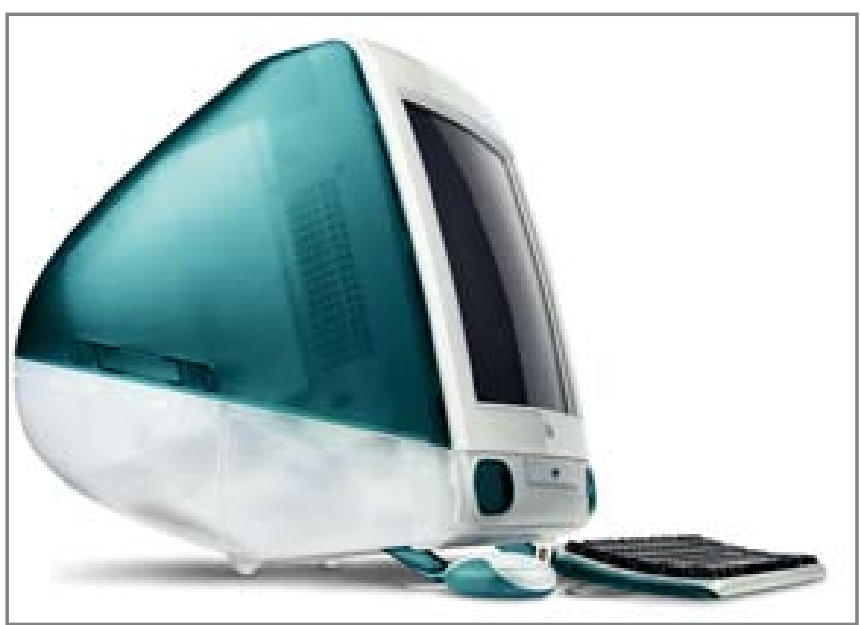

Fig 36. iMac. Design de Jonathan Ive e Apple design team. Fabricado pela Apple (SELLERS org., 2007). 


\section{3}

Após análise dos estudos sobre a possibilidade do Brasil desenvolver um padrão próprio de transmissão do sinal digital, foi decretado (Decreto $\mathrm{n}^{\circ} 4.901$, de 26 de novembro de 2003) o Sistema Brasileiro de TV Digital (SBDTV). O Decreto norteava a transição do padrão analógico para o digital e considerou a inclusão social por meio da TV como principal objetivo (BECKER; MONTEZ, 2005, p.135).

\section{5}

Surge nos Estados Unidos um canal a cabo chamado current.tv lançado pelo ex-vicepresidente americano Albert Gore Jr. Tratase de um canal 24 horas de jornalismo para jovens, que exibe cortes rápidos e muita informação. O interessante é que $20 \%$ do conteúdo exibido é produzido pelo próprio usuário (Disponível em: <http://www. current.tv>. Acessado em 28 de Abr de 2007).

\section{9}

O Google, ferramenta de busca de informações via web que nasceu como um projeto de pesquisa universitária, se tornou uma empresa real de grande demanda e ganhou reconhecimento e muitos prêmios do mercado (Disponível em: http: / / www.google. com/corporate/history.html. Acessado em 08 de Mai de 2007).

\section{1}

Em outubro a Apple lançou o primeiro iPod, um aparelho pequeno, pessoal e portátil que foi lançado com a principal finalidade de tocar músicas que podem ser baixadas da Internet. 0 iPod revolucionou a relação do consumidor com a música e se tornou um ícone da era digital. Ao ser lançado, o iPod podia armazenar até 4.000 músicas, um grande avanço frente aos outros aparelhos com a mesma função. 0 aparelho proporcionava ao usuário a compra de músicas online via iTunes, um software que organiza e também toca estas músicas compradas e/ou baixadas da Internet. Em setembro de 2006 o iPod chegou em sua quinta geração ao ganhar novas funções como a visualização de vídeos (SELLERS org., 2007). 


\section{6}

Os Estados Unidos deram largada na corrida pela implantação no país da televisão de alta definição. Até o ano 2006 todos os 24 milhões de aparelhos de televisão espalhados no país deveriam ser trocados por modelos que recebam os sinais digitais em HDTV. A decisão das autoridades americanas gerou ansiedade entre os responsáveis pelas emissoras de TV a cabo e por satélite. Pois a televisão de alta definição pede largura de banda muito grande para operar e por isso vai "comer" alguns canais ocupados pelas emissoras a cabo e por satélite; são problemas técnicos sobre cuja solução os engenheiros americanos ainda hoje se debruçam (SOUZA, 2002, p.11).

O presidente Luiz Inácio Lula da Silva assinou dia 29 de junho de 2006, em cerimônia no Palácio do Planalto, o decreto que regulamenta a escolha do padrão japonês para a TV digital brasileira (Disponível em: http: / / www1.folha.uol.com.br/folha/ dinheiro/ult91u109017.shtml. Acessado em 08 Mai de 2007).

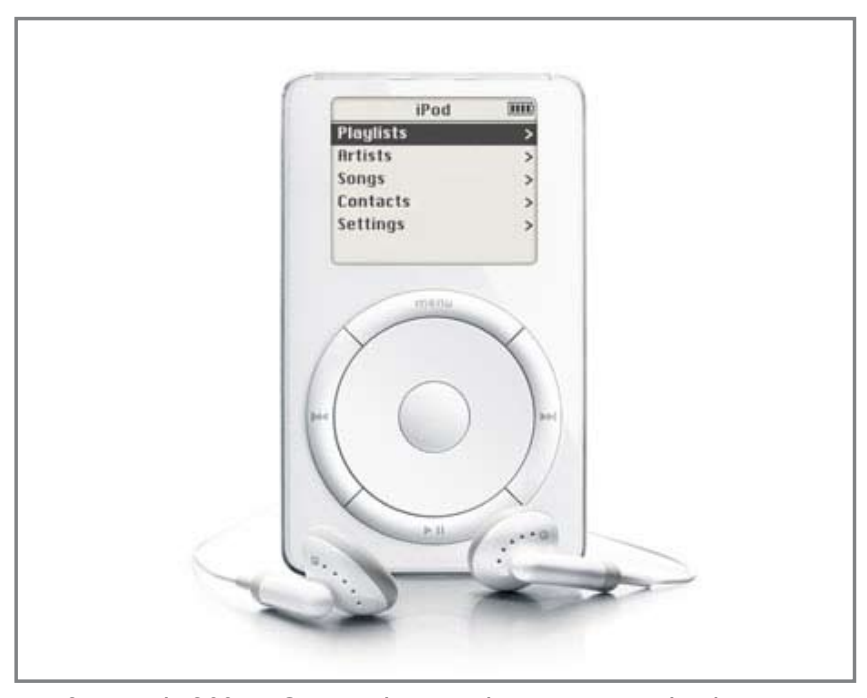

Fig 37. iPod (2001). Design de Jonathan Ive e Apple design team (SELLERS org., 2007).

\section{7}

Nascimento do Joost (www.joost.com). Os suecos, Janus Friis e Niklas Zennstrøm começaram a construir o projeto Joost em 2006 sob o codinome de The Venice Project. O Joost hoje, leva a TV ao globo terrestre como uma grande comunidade em rede (Disponível em: www.joost.com. Acessado em 08 de Mai de 2007). 


\subsection{Informação, mensagem e processo de comunicação. Design comunica.}

Estamos vivendo inovações sócio-culturais que formam a sociedade da informação. Esta vem em seguida da sociedade industrial e tem origem quando se percebe que caminhamos em direção a um novo modelo de organização, no qual o controle e a otimização dos processos industriais são substituídos pelo processamento e manejo da informação como chave econômica. Cada vez mais se produz informação ao invés de mensagens e cada vez mais pessoas dependem dela para viver. Nota-se que a informação circula como moeda corrente pois a sociedade não é mais baseada na mão de obra, nem no capital, mas na informação (SANTAELLA, 2004, p.1819). Cresce o poder da tecnologia como ferramenta para acessar a informação, o preço desta tecnologia cai e o consumo da mesma aumenta. Para sustentar a demanda, aumenta-se a produção, o arquivamento e a circulação da moeda (informação). Na era digital as mensagens e fontes se multiplicam, o que resulta numa audiência seletiva que escolhe as mensagens que deseja receber. Em outras palavras, o receptor que deseja acessar uma dada informação escolhe que tipo de mensagem deseja receber, e para que se faça a comunicação esta deve ser por ele percebida e compreendida.

A programação da TVI propõe hoje ao espectador algumas características que podem ser identificadas na Internet: diferentes possibilidades de interação. As mensagens e o conteúdo dessa programação são emitidos aos espectadores pela TV e englobam a utilização de códigos comuns ao repertório do emissor e do receptor. Estas mensagens são diferentes umas das outras, ou seja, comunicam tipos diferentes de informações e, portanto, se destinam aos perfis de espectadores correspondentes. O tipo de informação que vai constituir essas mensagens, os perfis dos espectadores para os quais elas devem comunicar algo e a competência em desenho são recursos que o profissional em design dispõe para elaborar um projeto que vise a criação das interfaces para TVI. A interface a ser criada deve ter o objetivo de transformar informações em mensagens inteligíveis para um dado espectador, de modo a potencializar diálogos entre ele e a programação disponibilizada.

O presente trabalho admite que o termo interface se refere ao "[... espaço no qual se estrutura a interação entre corpo, ferramenta (objeto ou signo) e objetivo da ação (BONSIEPE, 1997, p.12)”. Neste sentido, considera que as interfaces de TVI são o espaço no qual se estruturam a interação entre o espectador de TV, o tipo de informação e a tarefa que este espectador deseja realizar. 
Ou seja, "[...] revelam o caráter de ferramenta dos objetos e o conteúdo comunicativo das informações. [...] transformam sinais em informação interpretável (BONSIEPE, 1997, p.12)”19. A interface transforma informações em mensagens inteligíveis ao espectador, portanto, ela é o espaço onde ocorre o acoplamento de três elementos: a mensagem, o espectador de TV que deseja interagir com a programação e a tarefa que este espectador precisa realizar para, de fato, interagir. Ao projetar uma interface para TVI, o designer deve considerar o perfil do espectador que realizará uma ação efetiva nas práticas cotidianas de sua vida. Em outras palavras, que queira participar da programação de TV com o objetivo de obter um serviço ou produto que poderá facilitar de alguma maneira o seu dia-a-dia. Por se tratar de uma ação comunicativa que visa diálogos, este espectador terá que necessariamente ler e compreender a informação que está estruturada na tela da TV.

Portanto, o design de interfaces para TVI deve ser desenvolvido por meio de um projeto que visa, principalmente, o funcionamento de um processo de comunicação. Considera-se a TVI um dos meios que faz circular as mensagens "[...] que tem como principal característica propiciar a escolha e consumo individualizado, em oposição ao consumo massivo (SANTAELLA, 2004, p.15)." A mensagem emitida através deste processo deve provocar no espectador uma ação desencadeadora da comutação de informação, cuja estruturação está ligada ao processo de comunicação e compartilhamento. Essa informação é exibida de modo não linear caracterizando hipertextos ${ }^{20}$. Conforme Julio Plaza cita Laufer e Scavetta (2003, p.23), o hipertexto permite que o receptor abandone a linearidade do que está lendo em prol de um modo de escolha da informação não-linear e, portanto, mais dialógico. 0 espectador pode realizar saltos de um assunto para outro ou de uma página para a outra através de links. A interface deve revelar o conteúdo comunicativo do hipertexto viabilizando, assim que o espectador o explore, navegando por ele. Cabe ao designer ou criador, utilizando os recursos de que dispõe, articular um projeto ao selecionar e combinar elementos e um repertório a fim de criar, ordenar e apresentar mensagens. De acordo com Abraham Moles: 
"[...] Definimos a mensagem como uma seqüência de elementos tirados de um repertório, transportando uma informação proporcional à originalidade da mensagem, à sua imprevisibilidade, em relação a seu máximo possível - obtido somente se todos os elementos do repertório forem igualmente prováveis. É reduzida pela redundância, que exprime a influência de toda organização interna da mensagem, conhecida simultaneamente pelo receptor e pelo transmissor - mais geralmente no caso de uma mensagem natural, conhecida a priori pelo receptor. Toda redundância é expressão aleatória dos conhecimentos a priori que o receptor possui da mensagem; a redundância se opõe a informação numa dialética banal/original, mas condiciona a inteligibilidade dessa mensagem, criando aí uma organização interna (MOLES, 1978, p.184)".

Para criar as mensagens, o designer deve utilizar diferentes linguagens, tais como a gráfica, a textual e a sonora. A forma ${ }^{21}$ de apresentação destas mensagens deverá ser estruturada a partir da colagem de imagens, sons, movimentos e textos em um suporte único, caracterizando um ambiente hipermidiático. Melhor dizendo, a integração de sons, tipos de imagens, movimentos e textos dentro de um único ambiente de informação digital deverão ser apresentados ao espectador de TV.

Conforme diagrama baseado em Jakobson (2003, p.123), o funcionamento de uma mensagem ocorre tendo em vista a finalidade de transmitir através de um processo de comunicação. Esse processo se faz da seguinte maneira: um emissor emite uma mensagem que faz parte de um contexto a um receptor através de um canal, utilizando um código. Estes emissores, mensagem, receptor, contexto, canal e código são os seis fatores do modelo de comunicação criado por Roman Jakobson, que identifica as possibilidades de interpretação da mensagem. Cada fator da comunicação determina o perfil da mensagem que, por sua vez, determina a função da linguagem (JAKOBSON, 2003, p.123).

21 Para o autor Coelho Netto, uma tela, uma escultura, um filme podem ser descritos como mensagens, são grupos de elementos de percepção extraídos de repertórios determinados e com uma estrutura certa. Porém esses mesmos grupos de elementos, ficam melhor definidos como forma. Pois a forma é o conjunto de mensagens relacionadas entre si que resultam em um texto unitário (COELHO NETTO, 2003, p.122). 


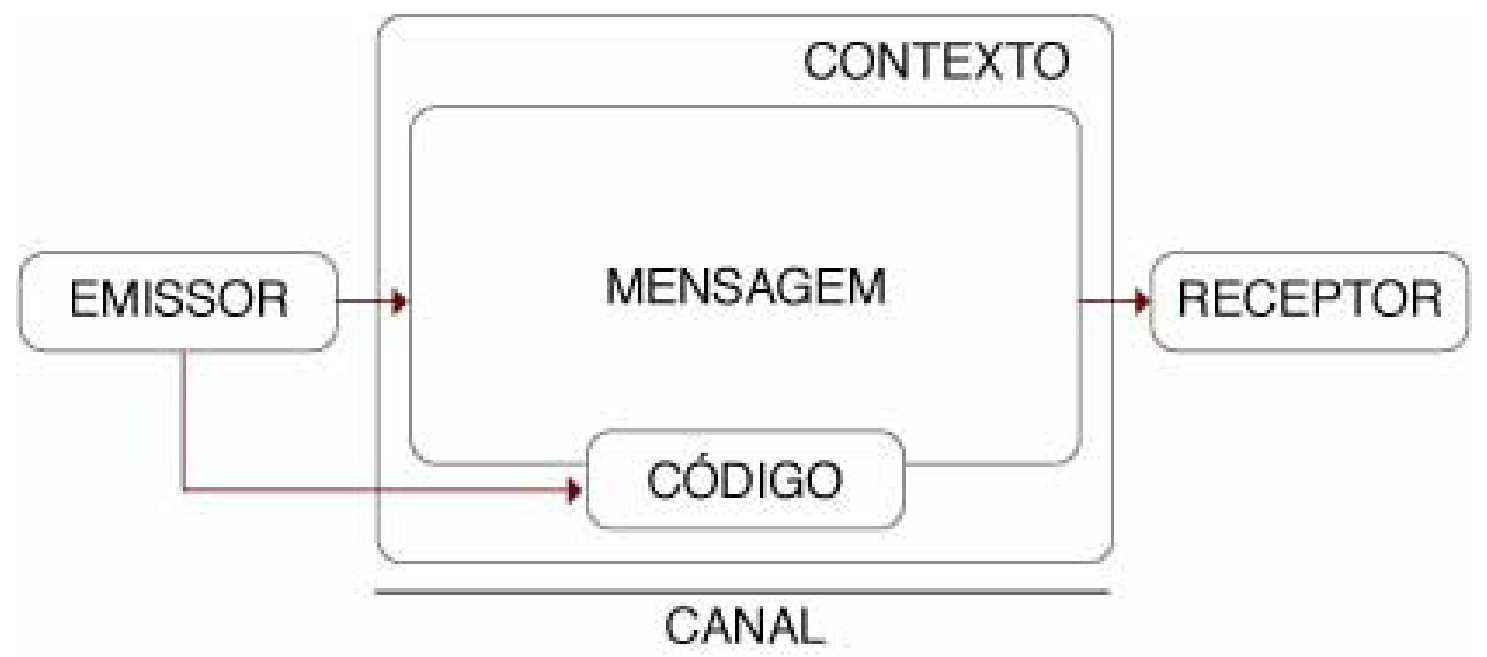

Fig 41. Diagrama dos fatores envolvidos na comunicação (JAKOBSON, 2003, p.123).

Pode-se identificar mais de uma função da linguagem presente numa mensagem. Estas funções são hierarquizadas e a que mais se destaca determina o seu perfil para que a comunicação aconteça de forma ordenada (JAKOBSON, 2003, p.123). Os fatores de comunicação são intransferíveis, se um deles não existe finda o intercâmbio desejado. Portanto, por exemplo, se a mensagem não tem conteúdo algum, se a audiência não existe, se o repertório não é comum entre receptor e emissor, se existe ruído ou ausência de canal, a comunicação não acontece (COELHO NETTO, 2003, p.131-134).

Cada mensagem transmitida através do processo de comunicação apresenta um perfil diferente de acordo com o fator da comunicação que o determina e que, por sua vez, determina a função da linguagem. Se a comunicação é determinada pelo referente, ou seja, contexto, a função da linguagem será a referencial, onde a predominância é a denotativa, produzindo mensagens claras, definidas e sem ambigüidades. Se o emissor é quem determina o perfil da mensagem, a função é a emotiva, pois aponta o ponto de vista do emissor em relação à mensagem. Se o canal é o determinante, a dominância é da função fática, que tem como característica a tautologia, quando a função da linguagem é a metalinguagem e ela opera com o código e o presentifica na mensagem. Quando a função da linguagem predominante é a poética, o fator da comunicação que a determina é a mensagem. A forma da mensagem é posta em evidência e são ativadas no receptor as capacidades de seleção e combinação em relação à atualização da linguagem proposta. Quando a função da linguagem predominante é a conativa, o fator da comunicação que a determina é o receptor. 0 objetivo da mensagem é persuadir o receptor e fazer com que ele dialogue com ela (JAKOBSON, 2003, p.123-129) 
Em casos extremos de ausência de comunicação pode-se notar a previsibilidade total da mensagem, ou seja, o signo novo sendo ininteligível. Isso pode ser positivo, pois o uso de um signo novo se insere no repertório deste receptor. Viu-se que quanto maior a taxa de novidade de uma mensagem, maior seu valor informativo e maior a mudança de comportamento provocada (alargamento de repertório). A novidade aí apresentada é a originalidade desta mensagem. 0 sistema de comunicação necessita de informação nova (original) para que novos signos sejam inseridos no repertório do receptor, alargando-o, e, também, para que haja a evolução do indivíduo ou grupo. Mas, inicialmente, apenas uma pequena parte da audiência compreende a informação nova, ou seja, apenas a audiência mais erudita detém um repertório amplo a ponto de adicionar a informação nova (COELHO NETTO, 2003, p.128-129). Apesar dos espectadores serem ávidos por novidade, esta deve ser emitida aos poucos e com altos níveis de redundância. À medida em que o repertório do telespectador é alargado, o nível de redundância cai e orientao na descoberta do novo. Cria-se um hábito e um debate cultural entre os telespectadores (usuários), o que possibilita uma maior integração e um maior desenvolvimento crítico.

Portanto, o desafio que o designer se coloca ao produzir as interfaces de TVI é comunicar por meio de sugestões e estratégias criativas que venham a instigar a capacidade reflexiva do espectador. A possibilidade de transformação de hábitos do espectador depende então da afinidade existente entre o seu repertório e o da produção. A busca do designer é se comunicar inovadoramente com vistas a instigar novas formas de ação. 


\section{CAPÍTULO II}

\section{INTERFACE DE TVI: PROJETO E DESIGN}

A cada dia a reflexão crítica ganha mais importância na área do design, em especial na época em que vivemos, onde as inovações tecnológicas e consequentes mudanças nos modos de criação, expressão, produção e desenvolvimento projetual são tão evidentes. Nesta dissertação de mestrado, a reflexão, a pesquisa e a análise crítica são entendidas como sendo de extrema importância para o trabalho do designer, na medida em que permitem resgatar, registrar e escrever a história ao demonstrar a importância e a abrangência desta profissão. Por muitos anos o design tem acompanhado os processos de mudança das culturas ao redor do mundo e, muitas vezes, antecipa e investiga as tendências. Mas ao mesmo tempo, o déficit que existe entre a teoria e a prática neste campo ainda não consegue explicar com precisão o que é design, informar sobre a importância do designer e explicar que design não é simplesmente desenho. A grande maioria de designers que desenvolve interfaces para Internet e TVI têm a sua formação proveniente muito mais de práticas de mercado do que do meio acadêmico. Estes profissionais são, muitas vezes, esforçados e talentosos operadores de softwares que utilizam como referência para sua criação o trabalho realizado sob a cultura de outras nações. Estes profissionais tem como objetivo reproduzir e, na maioria das vezes, não conseguem inovar.

Neste segundo capítulo, estudaremos o método heurístico do projeto, quando serão relacionados projeto e design como atividades constitutivas dos processos de desenvolvimento de interfaces de TVI. Consideraremos que a interface e a articulação do seu projeto é o objeto central deste estudo. Ao final, levantaremos algumas considerações acerca da questão do papel social do design no Brasil. 


\title{
2.1 A interface
}

\begin{abstract}
"No início da década de 1960, McLuhan fez a célebre observação de que viver com tecnologias elétricas e mecânicas ao mesmo tempo era 'o drama peculiar do século XX'. 0 grande drama das próximas décadas vai se desdobrar sob as estrelas cruzadas do análogico e do digital. Como o coro da tragédia grega, filtros de informação vão nos guiar através dessa transição, traduzindo os zeros e os uns da linguagem digital nas imagens mais conhecidas, analógicas, da vida cotidiana. Essas metaformas, esses mapeamentos de bits virão para ocupar praticamente todas as facetas da sociedade contemporânea: trabalho, divertimento, amor, família, arte elevada, cultura popular, política. Mas a forma propriamente dita será a mesma, apesar de suas muitas aparências, a labutar continuamente nessa estranha nova zona entre o meio e a mensagem. Essa zona é o que chamamos de interface (JOHNSON, 2001, p.35)".
\end{abstract}

Para Steven Johnson, a palavra interface se refere a softwares que dão forma à interação entre usuário e computador. Ela atua como tradutora, mediando entre duas partes, tornando uma parte sensível a outra (JOHNSON, 2001, p.17). Segundo o autor José Bragança de Miranda, a interface é algo que se coloca além da noção de superfície e profundidade. Trata-se de uma estrutura paradoxal sem verso nem reverso, o seu desdobramento interno constitui um espaço que liga e desliga ao mesmo tempo explorando todos os efeitos da divisão entre o que está na superfície e na profundidade (MIRANDA, 2004, p.1-20). Como dito anteriormente, para Gui Bonsiepe, a interface é o domínio central do design, pois é o espaço no qual se estrutura a interação entre o usuário, a ferramenta necessária para a realização de uma tarefa e a tarefa que este usuário deseja cumprir (BONSIEPE,1997, p.11-12).

\subsection{0 método heurístico do projeto.}

"O método de projeto não é mais do que uma série de operações necessárias, dispostas em ordem lógica, ditada pela experiência. Seu objetivo é o de atingir o melhor resultado com o menor esforço (MUNARI, 2002, p.10)".

Os métodos são ferramentas da mente para se atingir o insight, são o percurso que a mente utiliza para que se processe a criação. Nesse sentido, tornar-se-á importante evidenciar as diretrizes operacionais da criação que possibilitam estabelecer os mecanismos de descoberta no contexto do design. Nesta dissertação, defende-se que o método do projeto é o caminho ideal para o design de interfaces de TVI, pois esse tipo de projeto nasceu da idealização do produto, seguida da concepção e finalizando com a realização do mesmo. A concepção acontece em função da produção e o que predomina são: a estrutura mental, a semelhança, as qualidades 
icônicas e a sintaxe, onde o meio determina a maneira específica de trabalhá-lo (domínio das técnicas sobre o meio) (TAVARES, 2002, p.7-8).

O método do projeto será aqui utilizado na perspectiva proposta por Pignatari, da heurística ser "...ciência da decisão, da descoberta e da invenção, que se apóia em processos e processamentos de ordem estatística e probabilística, para chegar a decisões. Considerando que toda e qualquer informação nasce de seleções ante alternativas, o problema mesmo da decisão está intimamente ligado ao problema da criação, da invenção, da originalidade. Decidir é criar - e 'viver efetivamente é viver com a informação adequada' como declara Wierner (2002, p.65)".

O designer, em sua mente, seleciona e combina elementos do seu repertório a fim de obter um insight para solucionar o problema. Para chegar a essa solução, ele deve considerar os meios que o levarão a solucioná-lo, ou seja, "[...] ]as leis sintáticas preestabelecidas a serem seguidas na execução do elemento idealizado (PLAZA\&TAVARES, 1998, p.90)." Os autores, Plaza \& Tavares, propõem que o conjunto desses meios pode ser definido por um projeto, um programa, um modelo (paradigma) e atribuem importância especial ao aspecto construção, pois o elemento idealizado será o resultado do diálogo entre a estrutura instrumental e o projeto proposto, conforme esquema abaixo:

PROBLEMA > DEFINIÇÃO DO PROBLEMA > COMPONENTES DO PROBLEMA > COLETA DE DADOS > ANÁLISE DE DADOS > CRIATIVIDADE > MATERIAIS E TECNOLOGIAS > EXPERIMENTAÇÃO > MODELO > VERIFICAÇÃO > DESENHO DE CONSTRUÇÃO > SOLUÇÃO.

(MUNARI, 2002, p.29-56).

Nesta pesquisa, decidimos que vamos apenas cumprir o esquema até a fase modelo. PROBLEMA -> Oferecer a criança de classe A/B, que fica em casa por algum período do dia, atividades escolares ligadas a área das artes, via TVI. A escolha do problema deveu-se em razão de, dentro do contexto das artes dado o tipo de conteúdo do programa de TV, trazer à tona o papel social do design ao buscar-se fornecer informações educacionais ao público em questão.

DEFINIÇÃO DO PROBLEMA -> Introduzir conhecimentos de arte na vida cotidiana das crianças de classe $A / B$ do ensino fundamental ( $5^{\mathrm{a}}$ a $8^{\mathrm{a}}$ séries) e, com isso, também oferecer ao professor 
mais uma ferramenta de trabalho que possa envolver a família da criança no que diz respeito a tarefas de casa ${ }^{22}$.

COMPONENTES DO PROBLEMA -> Buscar-se-á investigar as seguintes questões: qual será o tema dentro do universo das artes? Como articular o projeto das interfaces de modo a envolver a criança que quer apenas assistir a TV, a que deseja participar e a que deseja interagir? Como distribuir as informações necessárias nas telas? Que tipo de meios vamos utilizar além da TVI? Como será a linguagem gráfica da interface? Como diz Munari (2002), depois da definição do problema, é importante desmontá-lo nas suas componentes para melhor conhecê-lo.

COLETA DE DADOS -> Pesquisa no site broadbandbananas (Disponível em: <http://www. broadbandbananas.com>) e transcrição dos vídeos contendo casos de interfaces de TVI. A partir desta pesquisa extraiu-se as seguintes funcionalidades para aplicativos a serem desenvolvidos no projeto a ser proposto:

- Quiz: perguntas e respostas.

- Loja: produtos a serem comercializados.

- Textos + Infográficos: Para aprofundamento do conteúdo programático da TV.

- Atividade (teletarefa): Sugestão de tarefa. A criança deverá realizar fora do meio televisivo.

ANALISE DE DADOS -> Dos casos investigados comentaremos seis (6) exemplos de interfaces com vistas a estabelecer uma diferenciação entre interação e participação.

CRIATIVIDADE -> Antes de se decidir pela solução bela e pronta, conforme Munari (2002, p.44-45), a fase da criatividade está implicada em todas as operações necessárias que se seguem à analise dos dados, ou seja, a criatividade garantirá a reorganização dos dados no intuito de os associar e de os combinar para o alcance da solução do problema (PLAZA; TAVARES, 1998, p.68).

MATERIAIS E TECNOLOGIAS -> Na falta de uma real plataforma de TVI utilizaremos o software Macromedia Flash 8.0 para a contrução de uma demonstração das telas e navegação entre elas.

22 A proposta apresentada visa despertar a possibilidade de usa da TVI no contexto do ensino da arte. Todavia, ainda configura-se como um modelo que contempla as especificidades de um projeto de design a partir do uso das tecnologias digitais. É importante destacar que para a definição do conteúdo final é necessário o envolvimento com profissionais da área do ensino da arte. 
A transposição desta demonstração para a plataforma de TVI deve ser possível após ajustes técnicos que não serão explorados nesta pesquisa.

EXPERIMENTAÇÃO -> Pela experimentação pode-se descobrir novas aplicações para um material ou instrumento (MUNARI, 2002, p.48). O Macromedia Flash 8.0 é um software utilizado, por exemplo, para confecção de websites, peças de publicidade na Internet e apresentações multimídia em geral. Nesta pesquisa, este software será empregado para construir uma demonstração de telas de TVI. Trata-se de uma nova utilização para este recurso (Macromedia Flash 8.0).

MODELO -> Construção da arquitetura de informação e demonstração.

Nesta etapa serão estabelecidas relações entre os dados recolhidos, no intuito de agrupar os componentes do problema e elaborar esboços para a construção do modelo. Decorrerão, portanto, a proposta da arquitetura de navegação e a elaboração da demonstração que as possibilidades tecnológicas e poéticas a serem usadas no projeto permitirem. Este modelo poderá vir a ser a solução para o problema (MUNARI, 2002, p.50).

Portanto, nesta fase conformamos a idéia de trabalhar com o desenhista brasileiro de historinhas em quadrinhos, Maurício de Souza e o seu livro História em Quadrões. Nesta obra Souza busca inserir um pouco de arte na vida das crianças ao criar pinturas dos seus personagens da Turma da Mônica parodiando obras de artistas famosos nacionais e estrangeiros. Além das paródias o livro também exibe obras originais e um descritivo sucinto sobre a vida destes artistas. A idéia então é formatar o conceito do livro de Maurício de Souza para a TVI e assim fazer com que as crianças, ao participar ou interagir com as historinhas, aprendam mais sobre o universo das artes.

Não foram exploradas as fases de verificação, desenho de construção e solução neste trabalho pois não foi possível, no decorrer do mesmo, o contato com uma plataforma de TVI disponível para alcançar a concretização do problema.

\subsection{A correlação entre projeto e design.}

Tudo que é percebido na TVI é conseqüência do design das interfaces. Neste meio ambiente televisual os designers trabalham com imagens digitais altamente manipuladas que se ocupam em 
esconder por exclusão. A possibilidade de edição de imagens digitais pode eliminar ruídos, como colocar cabelo numa pessoa careca, escurecer um ambiente muito claro, entre outros efeitos. Estas imagens, apesar de manipuladas, deveriam acompanhar a complexidade e seriedade de assuntos contemporâneos apresentados na televisão, mas isso não necessariamente acontece. Além delas retratarem visualmente a problemática de forma simples, ainda acrescentam um tom de entretenimento. Dessa forma torna-se difícil para o consumidor formar uma consciência crítica sobre assuntos contemporâneos, pois ele "lê" informações complexas de forma simplória e acaba percebendo-as como simplórias também. Portanto, não se trata de apenas prestigiar o design por trazer soluções de forma e função aos projetos e, sim, de colocá-lo no quadro de ação social, desde que o designer se preocupe em retratar assuntos da contemporaneidade de forma a despertar a consciência crítica do consumidor.

O processo de comunicação e compartilhamento dessas informações está ligado à sua apresentação. O projeto de interfaces, como maneira de apresentar estas informações (práticas e funcionalidades) e o processo de desenhá-las (forma e estética), é que deve produzir a articulação entre usuário e artefato (objeto que possibilita a ação do usuário). A informação é mediada por uma interface para que ela possa ser percebida e assimilada pelo consumidor. De outra forma ficará abstrata e poderá não ser acessada e experimentada (BONSIEPE, 2000, p.3). $\mathrm{O}$ design deve ser colocado em espaço de confronto para que ele aconteça como projeto. 0 design demonstra fazendo com que o consumidor experimente.

\section{Projeto}

"O projeto é a possibilidade da invenção de um novo produto, de outra cultura, de outro cotidiano (FERRARA, 2002, p.50)."

Segundo Bruno Munari, "[p]rojetar é fácil quando se sabe como fazer" (2002, p.2). 0 designer precisa do conhecimento do método de projetar, ou seja, do conhecimento das várias maneiras para se planejar e construir uma interface para a TVI. O designer Gui Bonsiepe defende que "[o] objetivo da atividade projetual não é a produção de conhecimento nem a criação do know-how técnico, mas a articulação da interface entre usuário e artefato (1997, p.37)”. Esta articulação traz inovação para as práticas da vida social e cotidiana através da linguagem dos juízos que se refere às características prático-funcionais e estético-formais (BONSIEPE, 1997, p.37). O projeto em design está relacionado à inovação e o designer deve estar envolvido em 
todo o processo para que se faça algo realmente inovador no sentido de gerar novas práticas na vida cotidiana do usuário. No âmbito do projeto em design, o processo é mais importante que o produto. Pois quando é o resultado final que conduz o processo, acabamos apenas visitando o mesmo lugar de sempre, a possibilidade de inovar fica distante. Se forem as etapas do processo a conduzir o resultado, podemos inicialmente não ter a visão geral deste resultado, mas sabemos que a possibilidade em inovar está próxima e a de errar mais distante. Em síntese, não há oposição e sim hierarquia entre processo e produto.

\section{Design}

O sucesso do projeto de design encontra-se exatamente na satisfação do consumidor (BONSIEPE, 1997, p.35).

Desde o início da pré-história a atividade dos homens esteve vinculada ao seu entorno, ou seja, eles adaptavam o meio ambiente às suas necessidades cotidianas. Este pensamento o acompanhou ao longo dos anos e, também, na Revolução Industrial, marco do nascimento de uma sociedade que demandava ofícios específicos a ponto de gerar a figura do designer, profissional inventivo capaz de sintetizar conhecimentos sobre as necessidades humanas, produção tecnológica e arte. Para o historiador Rafael Cardoso Dennis, o termo designer passou a ser de uso corrente, como apelação profissional, no início do século XIX na Inglaterra e, logo depois, em outros países europeus ${ }^{23}$. Antes disso a sociedade utilizava os serviços de especialistas denominados artistas comerciais, como os tipógrafos, ilustradores de todos os tipos, retocadores que finalizavam as ilustrações e textos desenhados, letristas e outros. Muitos deles reuniam mais de uma destas habilidades e as suas artes eram produzidas em branco e preto e impressas em papel (2004, p.15-16).

Hoje em dia o designer deve além de dominar suas ferramentas de trabalho também ponderar que tipo de mensagem será transmitida ao conjugar imagens, sons e textos simultaneamente. Se são os designers os responsáveis pelo potencial que abrange todo o pensamento da disciplina design, então, este pensamento deve se estender e considerar o modo como são desenhadas as situações em que o design ocorre. Defende-se que o design de interfaces de TVI é uma atividade que se propõe a criar e a desenvolver projetos que, desde a definição de seus objetivos, ajudem 
a sanar necessidades humanas em seu contexto social. O design trata a questão da forma não só como algo que qualifica seu objeto, mas também como algo que oferece significado ao dar aos seus usuário prazer, informação e instrução (BUCHANAN, 1989, p.91).

Conforme há muito argumentaram Ruskin e Morris, o grande poder do designer de alterar a sociedade reside muito mais na forma das suas relações de trabalho do que nas formas que ele atribui a um determinado artefato. Existe uma tendência histórica no design a reduzir as questões éticas a questões estéticas, o que é fruto geralmente de uma análise insuficiente dos problemas a serem resolvidos (DENNIS, 2004, p.75). Considera-se que, à luz do método do projeto, design não é cosmética.

\subsection{0 papel social do design no Brasil.}

Para o Prof. Dr. Gustavo Amarante Bomfim, o desenvolvimento do design no Brasil foi moldado por três principais fatores, são eles: a influência do racionalismo funcionalista no campo da formação do designer, a busca pela identidade do design como profissão em um mercado de trabalho limitado que privilegia profissões da área tecnológica, a política do pragmatismo na qual a estética enquanto ciência perdeu significado (BOMFIM, 1995, p.5-7). Habitualmente o designer, imerso na rotina da sua profissão, não consegue intuir a efetiva incidência social da sua atividade. 0 design vai além de um serviço prestado à indústria, trata-se de um fenômeno social que não pode ser analisado separadamente, mas sempre em relação a outros fenômenos (MALDONADO, 1991, p.17).

Considera-se, que a interface da TV Interativa é um produto, ou seja, uma unidade entre forma e conteúdo desenvolvido pelo designer, e que este produto impõe que a experiência do espectador seja cada vez mais constituída de tarefas. A interface se caracteriza por uma "superfície" que contém desdobramentos internos de elementos variados que representam apenas o essencial para transmitir mensagens previamente determinadas em projeto. No momento em que o espectador assimila essas mensagens é que se insere o esforço crítico e a necessidade de repensar a politização deste tema por parte do designer. Segundo Dijon de Moares, os consumidores de hoje estão cada vez mais exigentes e informados. Eles procuram não apenas aquilo que precisam, mas também, o que gostam ou amam, ou seja, buscam produtos que lhes proporcionam, além da funcionalidade, também emoção e prazer (MORAES, 
2006, p.1). Dessa forma, o profissional de design, no âmago de suas atividades profissionais, deve preocupar-se em retratar assuntos da contemporaneidade, de modo a ter e, também, despertar a consciência crítica no consumidor em geral. Portanto, não é simplesmente uma questão de perceber a TVI como novidade e de forma contemplativa, mas sim, de percebê-la de modo a construir a condição necessária para efetuar a crítica.

O projeto experimental proposto foi desenvolvido no sentido de elaborar uma metodologia para o desenvolvimento de interfaces interativas de TV Digital voltadas a serviços em educação. A intenção é que estes serviços sejam aplicados ao contexto das artes, para crianças do ensino fundamental ( $5^{\mathrm{a}}$ a $8^{\mathrm{a}}$ séries) de classe social A/B. Pretende-se, também, que ele sirva como ferramenta de trabalho para seus professores. 0 projeto consiste na criação de interfaces de TVI para um programa de desenhos animados genuinamente brasileiro chamado A Turma da Mônica, de autoria do desenhista Mauricio de Sousa. Utiliza-se como base deste projeto o livro infantil História em Quadrões (2001) que detalharemos no próximo capítulo ${ }^{24}$. 


\section{TVI: CONVERGÊNCIA DE MÍDIAS}

Examinaremos a TVI na perspectiva de que as últimas décadas do século XX trouxeram muitos progressos tecnológicos para os meios de telecomunicação. A TVI só se tornou possível devido à chamada TV Digital ou TV de Alta Definição (HDTV - High Definition Television). Trata-se de um sistema de transmissão de dados por meio de código binário (a transmissão analógica é feita por ondas eletromagnéticas). 0 som e a imagem são digitalizados, ou seja, transformados em séries que combinam os dígitos 0 e 1, tratando-se da mesma linguagem utilizada por computadores. As vantagens desta transmissão são a ausência de interferências, melhor qualidade de imagem e som, maior variedade de canais (mais de 150 podem ser recebidos) e a possibilidade de usar recursos interativos relacionados ao envio de imagem, som e também de dados através de códigos binários. O que se pôde observar com base na coleta e análise de dados realizadas é que o design de interfaces de TVI é fortemente semelhante ao design de interfaces de websites na Internet. As interfaces de TVI, em sua maioria, mostram-se muito pouco elaboradas em termos de projeto, o que nos conduz a hipótese de que tecnólogos estão desenvolvendo-as e os profissionais de design ainda não parecem estar envolvidos no processo de criação das mesmas.

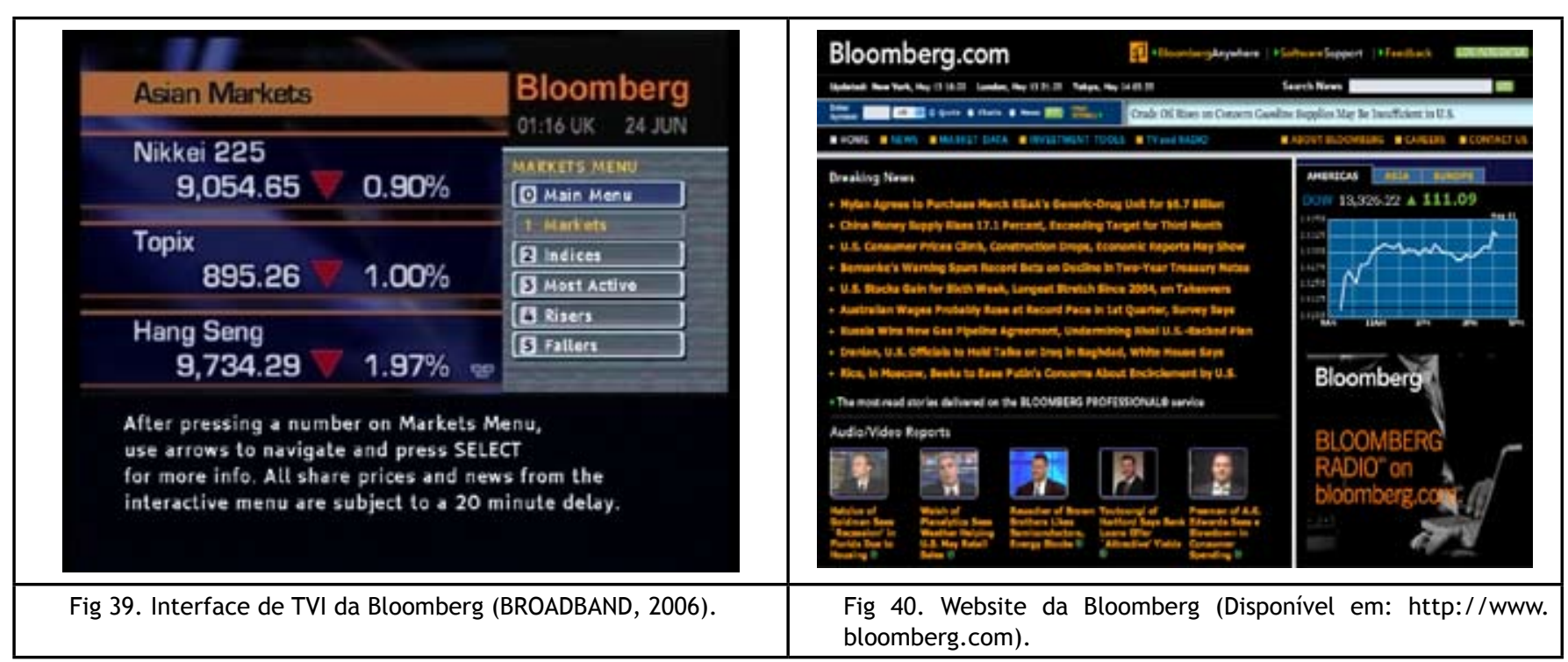




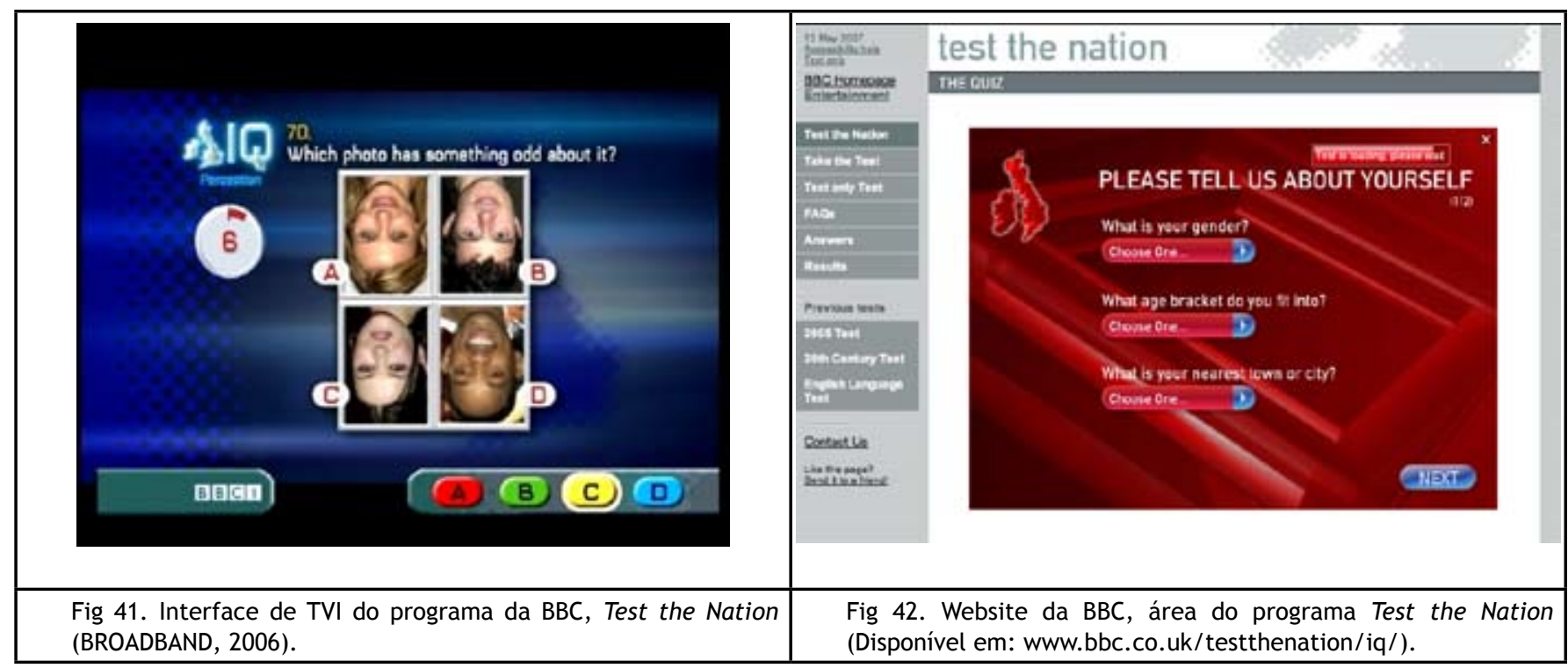

\subsection{Estudo de casos}

Em sua grande parte, as interfaces pesquisadas permitem a ação do espectador sobre elas, retornando-lhes resultados programados e previstos. Estas interfaces podem se apresentar como hiperdocumentos ${ }^{25}$ em que se destaca a finitude de possibilidades ou hiperdocumentos que se configuram como um campo dos possíveis a ser explorado. Todavia, algumas poucas interfaces mostram-se em fluxo contínuo. Neste caso, como diz Lévy (1999, p.62), dados dispersos entre memórias e canais fluem pelo ciberespaço. É o caso da interface 04, Aol on Sky digital, a ser apresentada.

A atenção do espectador se volta para as imagens representadas e se efetua entre estes uma conexão espaço-temporal que tem como objetivo comunicar algo. 0 envolvimento do espectador se efetiva por meio de uma ação ao pressionar os botões do controle remoto da TV, e assim ele vai construindo sua experiência. Por outro lado, a interface procura incorporar o espectador como parte integrante dos acontecimentos que se seguem e o transforma em ator e agente da construção das próximas situações. Das interfaces pesquisadas, observa-se que na maioria das vezes ocorre uma simples reação ${ }^{26}$ do espectador pois ele sempre está a estabelecer uma conexão física com a interface por meio do controle remoto da TV, o que indica a relação de contato com as imagens apresentadas nesta interface, não predominando a interação ${ }^{27}$ pois todas as possibilidades de respostas por parte da interface são previstas e programadas. 


\subsection{Apresentação dos casos selecionados ${ }^{28}$}

a) Interface 1

UK Sky - BBCi Pyramid Challenge (BROADBAND, 2006).

Descrição:

O Pyramid Challenge é um programa da BBCi britânica. Esse programa é exibido 24 horas por dia via satélite digital. De acordo com a BBC, o Pyramid Challenge é a primeira história interativa da TV no mundo. 0 programa é montado por meio de quatro entradas separadas que são alimentadas por diferentes vídeos. 0 usuário é induzido a escolher o seu próprio caminho na aventura ao pressionar os botões do controle remoto. A narrativa do Pyramid Challenge encoraja o usuário a ser observador e a guiar o apresentador por uma série de situações desafiadoras no Egito atual. O programa acompanha a jornada de Londres, via Aswan, no extremo sul do Egito, até a cidade de Saqqara onde foram inventadas as pirâmides. Na grande Pirâmide em Giza os usuários enfrentam o desafio final: abrir a câmara escondida do faraó. Se o caminho correto é escolhido, o usuário é recompensado com um número que faz parte de um código secreto para abrir a tumba e concorrer a um feriado de sonhos no Egito.

\begin{tabular}{|l|l|l|l|l|l|l|}
\hline & \\
\hline
\end{tabular}

28 Os casos apresentados são fragmentos de vídeos gravados por usuários no momento de diálogo com as interfaces. Estes pequenos vídeos foram transcritos a partir do site BroadBandBananas, conforme referido no item 2.2. 
b) Interface 2

Driving viewers to Sky News Active Voting (BROADBAND, 2006).

Descrição:

O programa telejornalístico da SKY, Sky News, leva sua audiência a participar via controle remoto, e, desse modo, promove serviços que agregam valor a sua programação e asseguram a retenção do usuário. No segmento dos boletins de notícias é feita uma enquete que só se aplica a uma pequena escala da audiência, como por exemplo aos usuários que se interessam pelas notícias do mercado financeiro. Durante o boletim um aviso na tela aparece (prompt $\left.{ }^{29}\right)$, levando os usuários que desejarem se aprofundar mais na notícia a responder a uma pergunta, relacionada a esta notícia, proposta pelo apresentador. Ao pressionar os botões verde ou vermelho do controle remoto os usuários se decidem por responder entre sim e não. 0 resultado da enquete é, em alguns segundos, exposto na tela da TV (Fig.50).

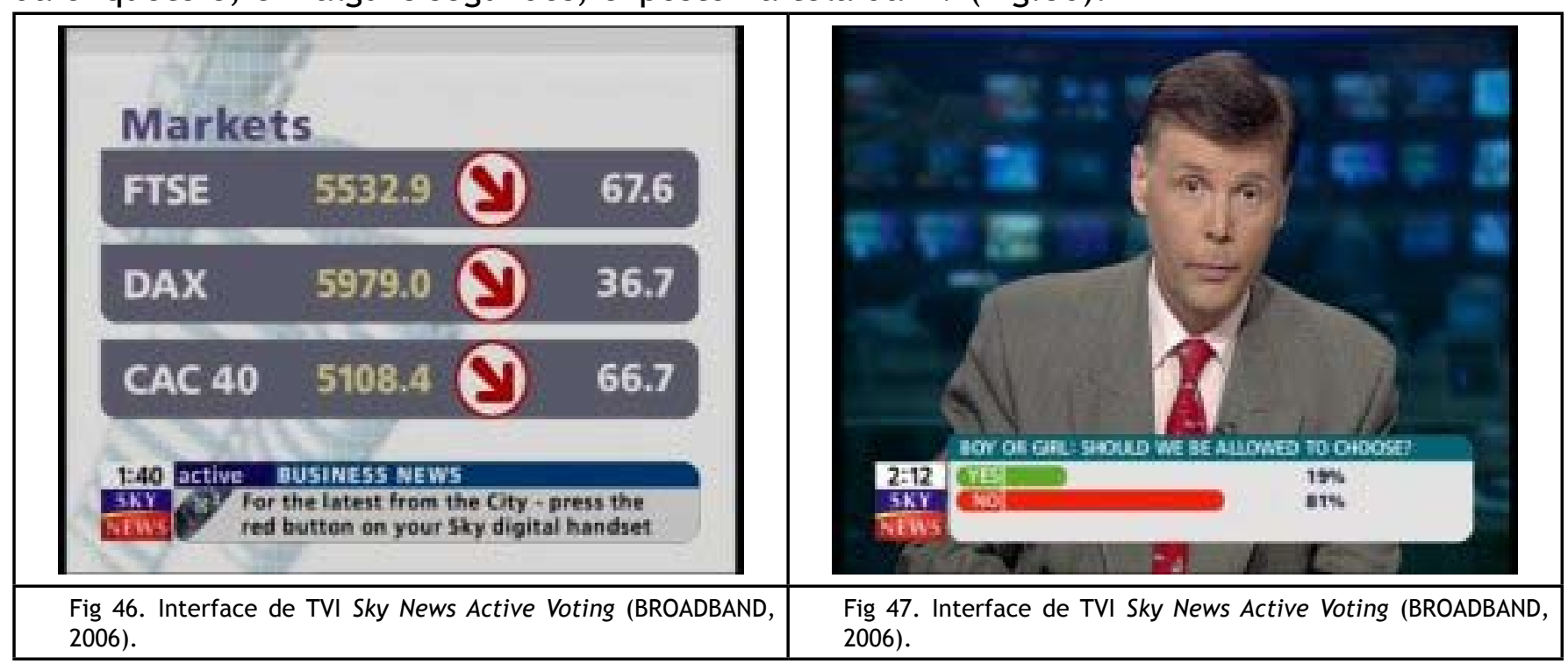

29 Chama-se de prompt o sinal que indica que naquele exato momento existe a possibilidade do usuário interagir com o programa de TVI. 


\section{c) Interface 3}

UK Sky - Living TV Active (BROADBAND, 2006).

\section{Descrição:}

A Living TV do Flextech lançou um novo portal na Sky Digital TV. O portal televisivo oferece uma gama de serviços incluindo horóscopo, competições e até leituras de perfis psicológicos. O serviço de horóscopo é atrativo, fácil de usar e grátis - ainda que o aprofundamento no seu conteúdo seja possível apenas mediante pagamento de uma taxa de 60 centavos de libra esterlina por minuto via telefone. 0 portal também oferece um Love Match ${ }^{30}$ onde o usuário pode testar sua compatibilidade com um parceiro ao consultar dados disponíveis em um banco (sinais escritos nas estrelas conforme a metáfora proposta para o programa). Este serviço requer que o hardware chamado setop box se conecte a uma linha telefônica para receber o conteúdo mediante o pagamento da taxa de 25 centavos de libra esterlina.

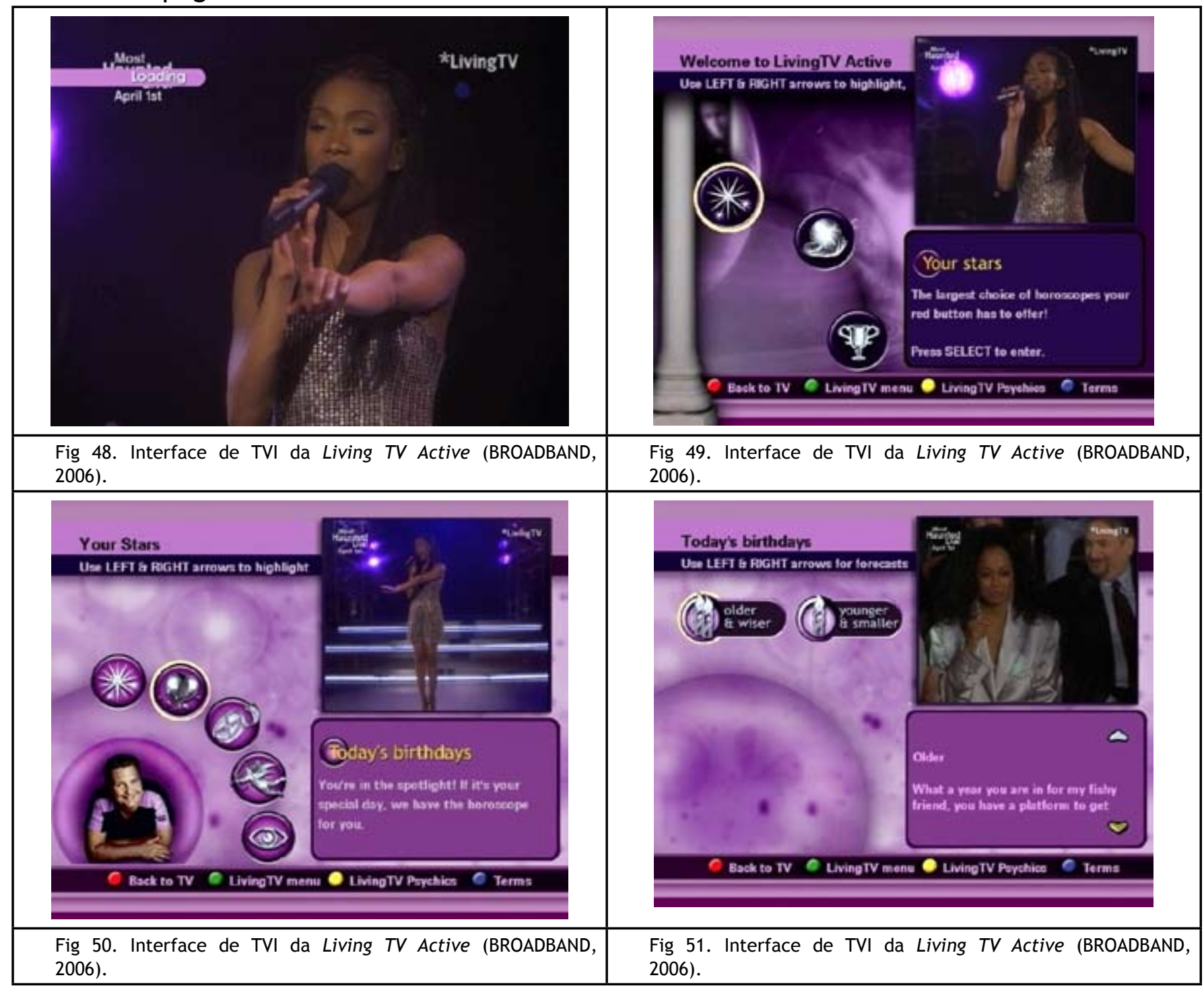




\section{d) Interface 4}

EMA Voting Application on CSD Spain (BROADBAND, 2006).

\section{Descrição:}

Um elemento gráfico (prompt), que aparece rapidamente no canto superior direito da tela de TV, induz o usuário a pressionar o botão "SERV" do seu controle remoto. O canal de TV relacionado ao aplicativo é o MTV Spain, por isso, ao pressionar o botão o usuário é levado a interface de TVI do EMA (España Music Awards) 2002. Lá ele pode votar no seu artista ou banda musical preferido e, assim, concorrer a um convite para participar do evento da entrega de prêmios em Barcelona.

O aplicativo de TVI pede que o usuário vote em cinco categorias: melhor artista espanhol, melhor banda, melhor artista feminina, melhor artista masculino, melhor single e melhor álbum. As categorias são votadas via controle remoto e os resultados transmitidos de volta ao usuário e exibidos na tela da TV via modem do setop box pelo custo de uma ligação local.

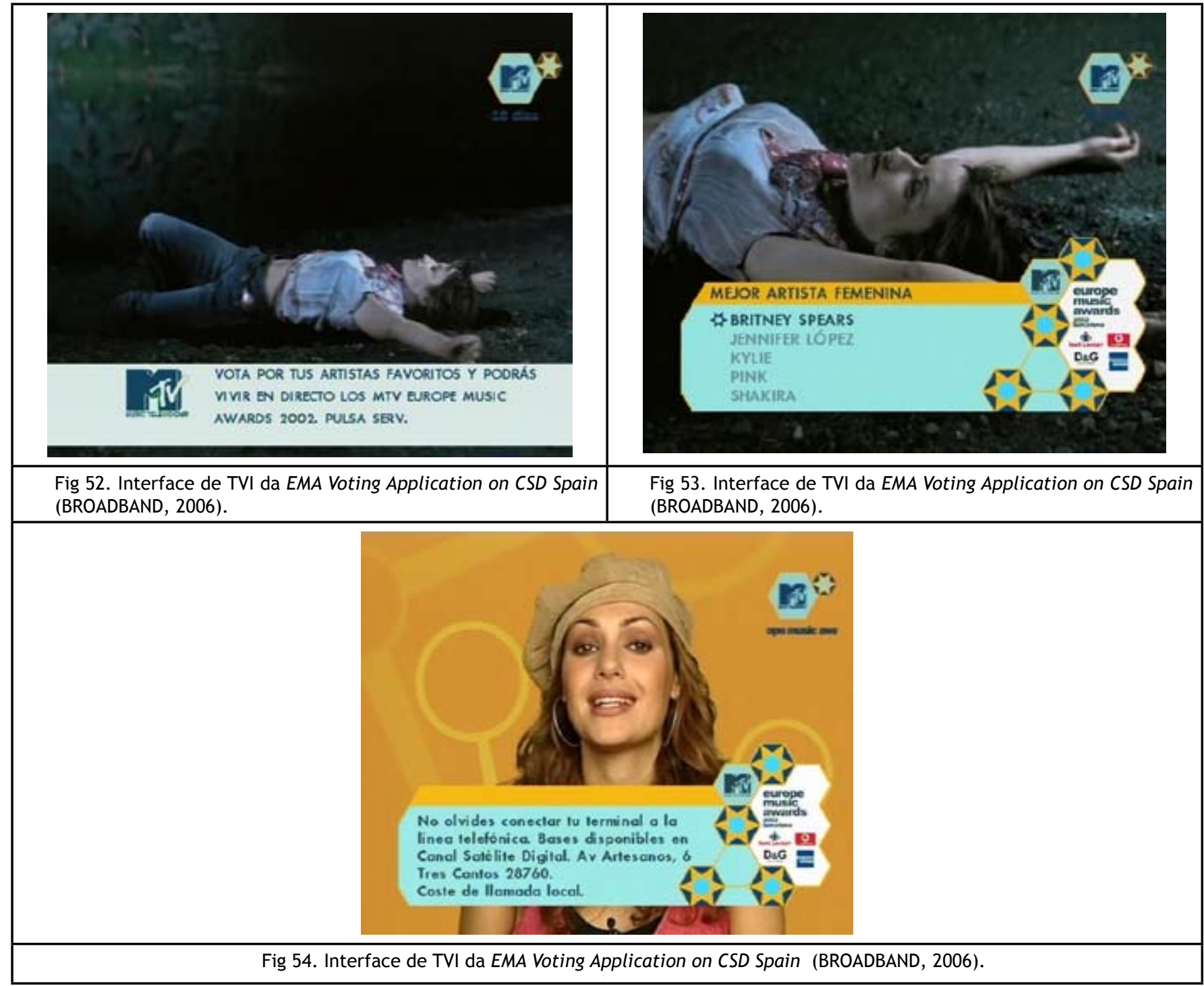


e) Interface 5

AOL on SKY digital (BROADBAND, 2006).

Descrição:

Este serviço surgiu no mercado alavancado pelas experiências em serviços de telefonia móvel e WAP (Wireless Applications) da AOL (American Online) e da tecnologia WapTV da Sky.

O serviço que combina mensagens instantâneas, notícias e condições do tempo está disponível na Sky TV para os assinantes da AOL. Estes usuários podem acessá-lo a qualquer momento, apenas pressionando o botão vermelho do seu controle remoto enquanto assistem ao canal Sky. No momento de acesso ao serviço o usuário deve inserir seu nome e e-mail na interface de TVI que aparece para ele. Uma vez utilizando os serviços pode-se continuar assistindo ao programa de TV que lhe aparece em modo de $1 / 4$ da tela. Escrever textos pelo controle remoto é possível, mas muito lento. O usuário pode também utilizar um teclado wireless próprio da Sky.

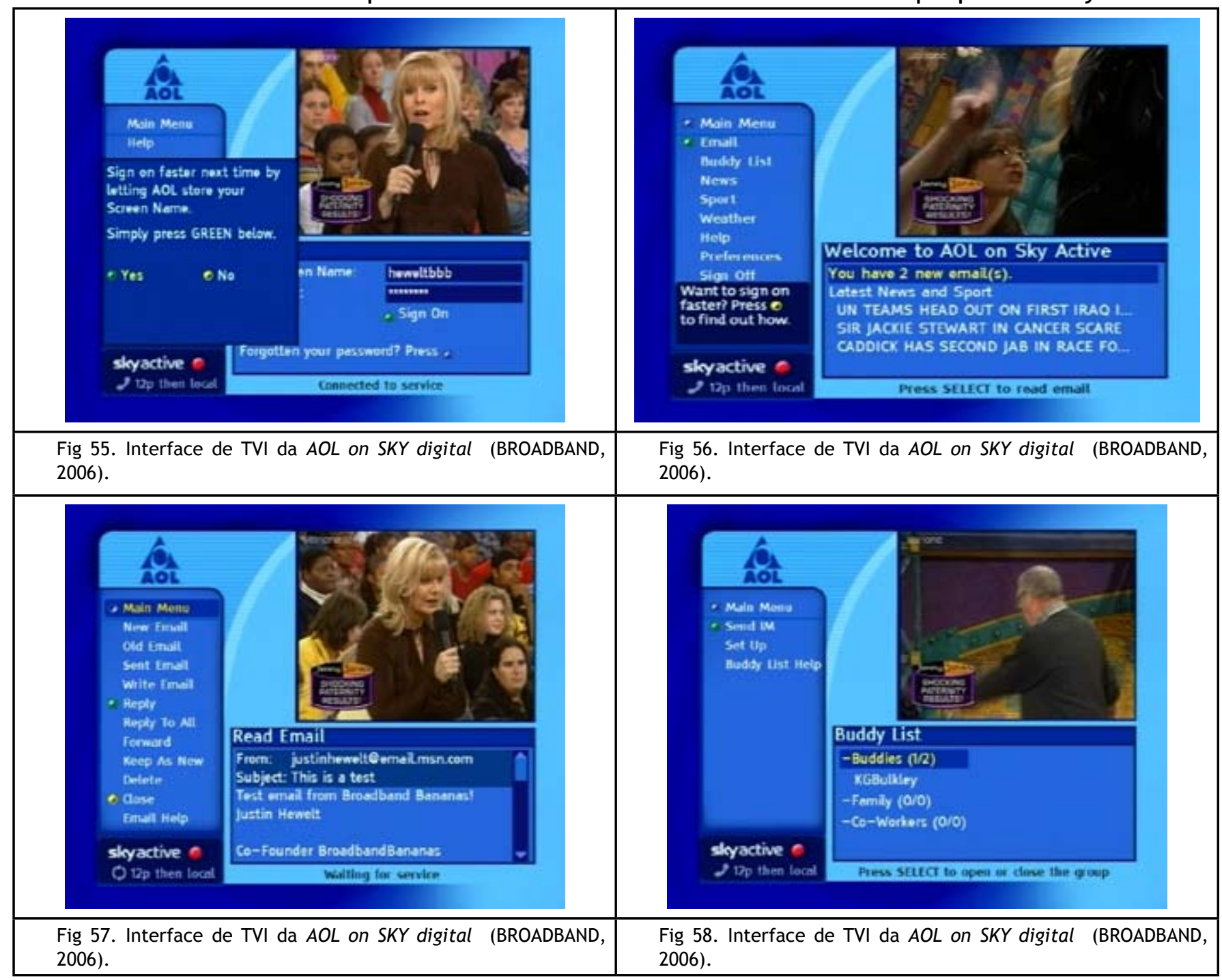




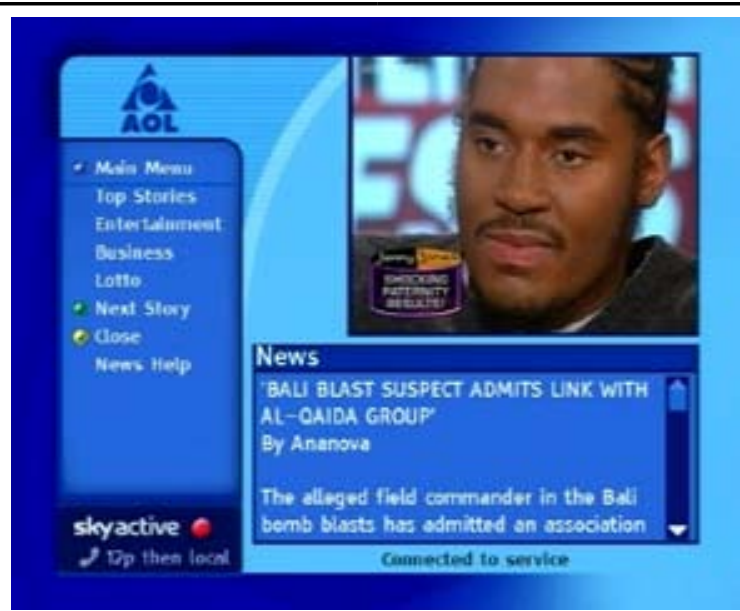

Fig 59. Interface de TVI da AOL on SKY digital (BROADBAND, 2006).

\section{f) Interface 6}

BBC CBeebies on Sky Digital (BROADBAND, 2006).

Descrição:

Os jogos CBeebies podem ser acessados pelo canal CBeebies na Sky Digital e também pelo portal de teletexto da BBC. Os jogos são atualizados com certa regularidade. 0 jogo que temos como exemplo é baseado em personagens infantis clássicos: Bill e Ben. Procura-se atingir crianças com idade pré-escolar, por isso os jogos são bem simples e incentivam o uso de cores e formas.

Efeitos de som e de animação também são pouco elaborados.

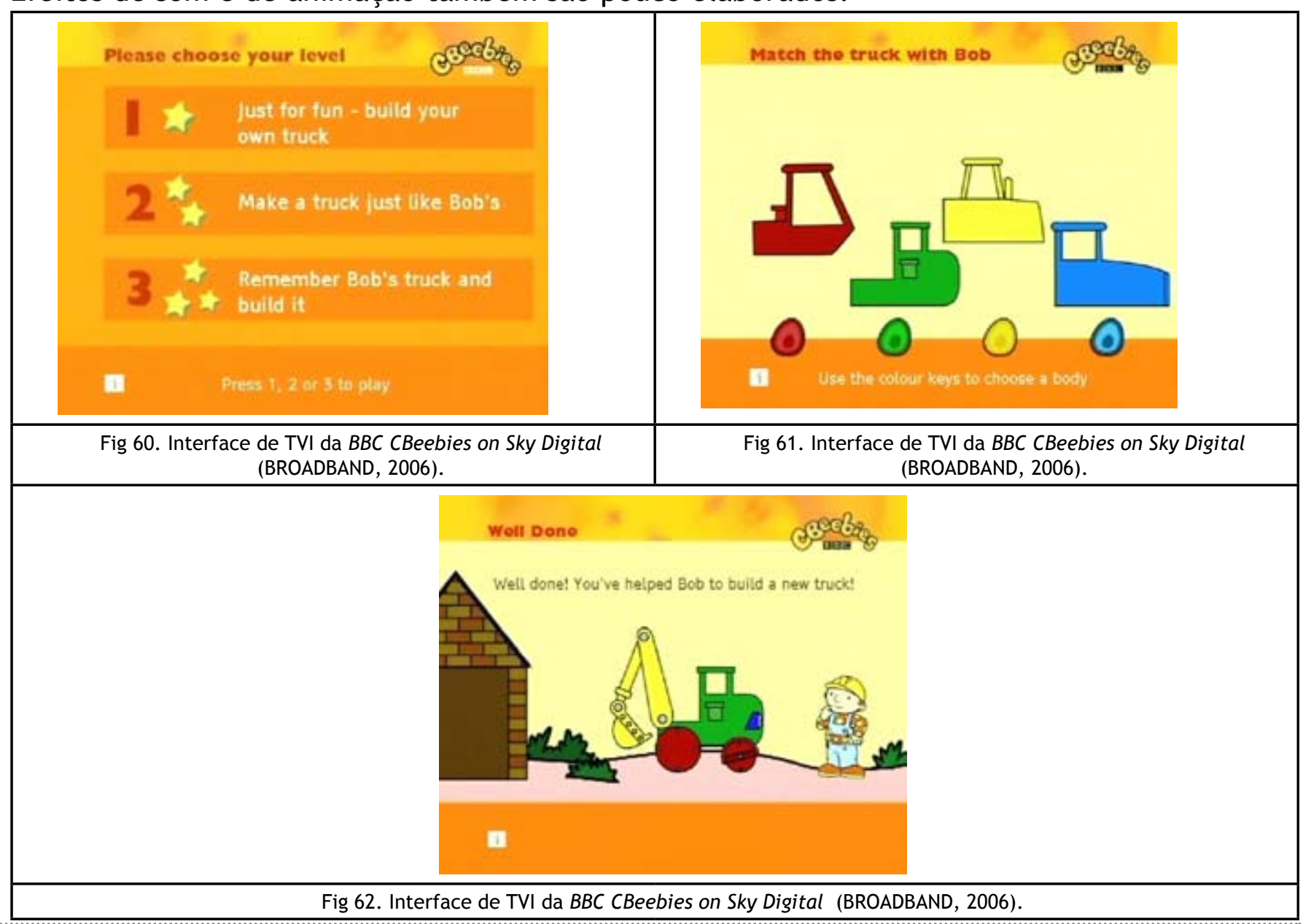




\subsubsection{Reação ou interação?}

Entende-se que o design é uma atividade integrada ao conjunto das práticas mercadológicas das indústrias. Portanto, não é apenas uma atividade que tem como objetivo oferecer um desenho bonito aos produtos e serviços industrializados, mas também trata-se de uma atividade de projeto, onde a experiência do consumidor deveria ser o mais importante. É a capacidade que o design tem em demonstrar e comunicar uma mensagem, juntamente com a competência que o designer tem em desenho, que vai oferecer ao consumidor uma experiência efetiva ou não em relação ao produto ou serviço de uma determinada organização. A questão das possibilidades de interação dos usuários nos meios de comunicação está diretamente ligada às práticas mercadológicas das indústrias e, consequentemente, envolve a atividade do design como meio para o alcance de suas prerrogativas. E é aí onde se encontra a problemática de se garantir as necessidades dos indivíduos como forma de sua inserção no contexto social.

Torna-se difícil dissociar o termo interatividade da noção de tecnologia pois os dois caminham muito juntos. Mas, defende-se nesta pesquisa que o fenômeno da interatividade não se resume ao âmbito simplesmente técnico e instrumental, é mais amplo que isso. Para Tavares, a interatividade deveria se configurar como um fenômeno potencializador de processos de recriação (2002, p.39-41). A interatividade pode ser vista portanto como uma qualidade própria das NTC que visa "[...] garantir ao receptor a possibilidade de intervir sobre a mensagem, ao atualizar os estados possíveis de sua matriz operacional (TAVARES, 2002, p.39)” (grifo nosso).

Na tentativa de observar os tipos de ação do usuário presentes nos exemplos de TVI mostrados anteriormente, vamos nos embasar na tabela proposta por Tavares (2002, p.48), produzida com base em Lévy (1999, p82-83) denominada "As possibilidades estruturais da interatividade" 31. Esta tabela mostra, por um lado, as possibilidades estruturais de constituição das mensagens, e, por outro, as possibilidades de relações entre participantes. E, para tanto, focaliza dois níveis de variáveis: os dispositivos informacionais e os dispositivos comunicacionais. Para Lévy (1999, p.62), os dispositivos informacionais qualificam a estrutura da mensagem que pode ser linear, em rede, ou ainda caracterizar-se como mundos virtuais, em que a informação se dispõe no espaço contínuo e o explorador ou seu representante está imerso no espaço, ou também, como fluxos de informações que desígna dados em estado contínuo de transformações. Neste 
trabalho considera-se a mensagem em rede e em fluxo de informações.

Já a reciprocidade da comunicação, ligada ao eixo dos dispositivos comunicacionais, designa a relação entre participantes da comunicação. Ainda segundo Lévy (1999, p.63), pode-se distinguir três categorias destes dispositivos, são elas: um-todos, um-um e todos-todos. A categoria umtodos se explica como sendo um centro emissor que envia mensagens para um grande número de telespectadores passivos e dispersos (por ex.: TV aberta e rádio). Assim sendo, assim esta categoria não será considerada nesta pesquisa, pois o nosso objeto de estudo (TVI) já pressupõe que o telespectador não será passivo nem disperso dentro do processo comunicacional. Dentro da categoria um-um pode-se citar como exemplo o telefone ou o correio. Esta coloca em contato dois indivíduos, organiza relações recíprocas entre interlocutores, mas apenas para contatos de indivíduo a indivíduo ou ponto a ponto. Já na categoria todos-todos se permite que as comunidades constituam de forma progressiva e de maneira cooperativa um contexto comum. Nesta categoria pode-se ter como exemplo os Blogs (ex.:www.blogspot.com), as comunidades como o Orkut (www.orkut.com) e os fóruns de discussão online.

Nesta pesquisa, as interfaces constituem a peça que potencializa o engendramento das possibilidades de interação e de apropriação por parte do receptor e a TVI firma-se como dispositivo comunicacional que garante a relação entre os participantes da comunicação. As interfaces se comportam como o espaço de troca. 0 conteúdo informacional exibido nas interfaces de TVI referidas no item 3.2 são estruturadas em fluxo de informação ou rede como hiperdocumentos, seja como finitude de possibilidade ou campo dos possíveis. No primeiro caso, são sistemas em que se tende a uma relação "não mediatizada" ou interpessoal, que implica em um tipo de representação dada pelo diálogo entre indivíduos. No caso dos hiperdocumentos em que domina a finitude de possibilidades, o receptor atualiza apenas o potencial de escolhas embutido nos sistemas fechados. Já nas experiências em que domina um campo de possíveis a explorar percebe-se o "efeito de liberdade". Com base em Tavares (2002, p.46) esta noção proposta por Lippmann (apud. Vittadini, 1995) implica a simulação de uma liberdade de diálogo dada pelo modo de configuração da interface.

A tabela abaixo identifica as possibilidades de interação de acordo com o modo como o receptor se relaciona com as mensagens contidas nas interfaces de TVI 1, 2, 3, 4, 5 e 6 apresentadas 
Tabela 01.

\begin{tabular}{|c|l|l|l|}
\hline \multirow{2}{*}{$\begin{array}{c}\text { DISPOSITIVOS DE } \\
\text { COMUNICAÇÃO: } \\
\text { TVI }\end{array}$} & $\begin{array}{l}\text { Em rede } \\
\text { hiperdocumentos } \\
\text { finitude de possibilidades }\end{array}$ & $\begin{array}{l}\text { Em rede } \\
\text { hiperdocumentos } \\
\text { campo dos possíveis }\end{array}$ & Em fluXO \\
\hline UM-UM & & $\begin{array}{l}\text { Interface 1 } \\
\text { Interface 6 }\end{array}$ & \\
\hline TODOS-TODOS & $\begin{array}{l}\text { Interface 2 } \\
\text { Interface 4 }\end{array}$ & Interface 3 & interface 5 \\
\hline
\end{tabular}

Com base na tabela da Tavares (2002, p.48).

São os novos dispositivos informacionais (mundos virtuais e fluxos de informações) e comunicacionais de categoria todos-todos que são os maiores portadores de mutações culturais, e não o fato de que se misture texto, imagens e som, como parece estar subentendido na noção vaga de multimídia (LÉVY, 1999, p.63). Com esta afirmação considera-se que somente a interface 5 apresentada tende a ser caracterizada como interativa em seu mais alto grau visto que o receptor tem a capacidade de inserir dados e interferir no conjunto da informação.

Contudo, vale observar que esta interface contém aplicativos característicos da Internet que não se relacionam de nenhuma forma com o programa de televisão exibido. Os aplicativos podem ser acessados pelo usuário a qualquer momento e, de forma independente, o programa é exibido em 1/4 de tela. A interação do usuário não modifica a programação de TV, ou seja, programa de TV e aplicativos funcionam em um mesmo "lugar" mas não dialogam. Enfim, esta interface nada mais é que uma representação similiar de um aplicativo da Internet.

\subsection{Articulação do projeto: História em Quadrões.}

O projeto História em Quadrões (2001) do desenhista brasileiro de história em quadrinhos Mauricio de Sousa, foi criado com o intuito de incentivar a criatividade e divulgar a arte de uma maneira divertida para os admiradores dos quadrinhos Turma da Mônica. 0 autor desenhou seus personagens parodiando obras de renomados artistas nacionais e internacionais e, dessa forma, contou um pouco da vida e da obra deles. "Minha história com os 'Quadrões' começou 
por brincadeira. Em uma visita que fiz ao Masp - Museu de Arte de São Paulo, no final dos anos 80, parei para observar Rosa e Azul, uma das obras que mais gosto do pintor francês Augusto Renoir” (SOUSA, 2001, p.9). Desta brincadeira, resultaram dez anos de pesquisas e a exposição "História em Quadrões" que já percorreu museus de São Paulo (Pinacoteca do Estado), Rio de Janeiro (Museu Nacional de Belas Artes) e Salvador (Conjunto Cultural Caixa) reunindo um público estimado em 500 mil pessoas. Seus visitantes não apreciaram apenas os personagens dos quadrinhos, mas também puderam entender um pouco de arte de forma fácil e divertida ao entrarem em contato com Monet, Botticelli, Van Gogh, Degas, Michelangelo, Toulouse-Lautrec, Renoir, Portinari, Almeida Júnior, Anita Malfati e outros grandes artistas. A mostra ainda seguiu para outras capitais brasileiras, Europa e Estados Unidos. Mauricio de Sousa revela que além de visitas ao MASP, também esteve no Museu do Louvre, em Paris, onde crianças copiando Monalisa, também o impressionaram e o levaram a pensar em fazer o mesmo com as crianças brasileiras.

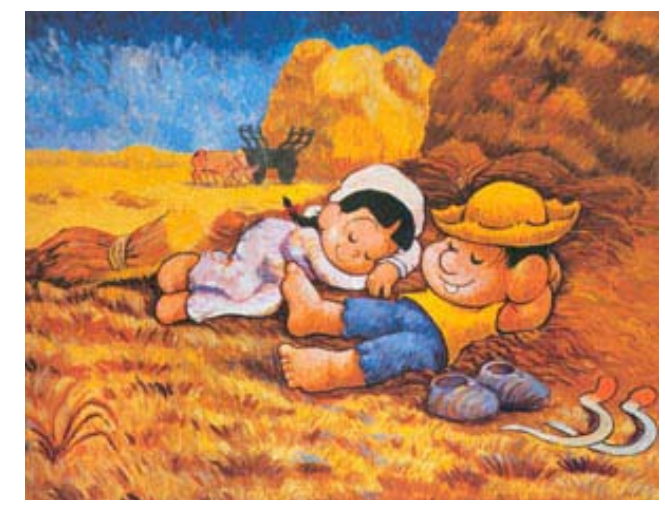

Fig 63. "O Cochilo" - baseado na obra "A Sesta" (SOUSA, 2001, p.42).

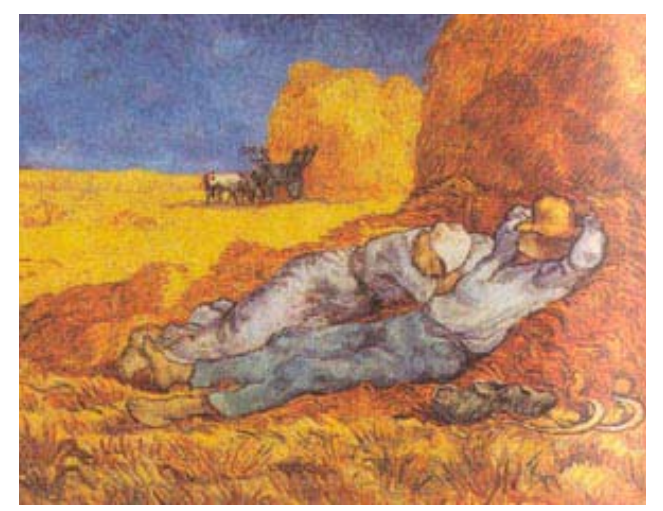

Fig 64. "A Sesta" (1890) - Van Gogh (SOUSA, 2001, p.42).

Nesses dez anos de pesquisa para desenvolver as releituras, o desenhista conta que procurou verificar detalhes das pinturas, como a utilização das tintas, o jeito das pinceladas, a iluminação. A diversão e a brincadeira do início, que somente eram vistas nas paredes dos corredores dos estúdios da Mauricio de Sousa Produções (em São Paulo), acabou virando trabalho sério, pintados em tinta acrílica com o máximo de fidelidade ao original. Até mesmo as molduras foram pesquisadas para que ficassem próximas das originais.

A idéia aqui é dar continuidade ao projeto "História em Quadrões" de Mauricio de Sousa inserindo-o também na TVI. O problema encontrado é: como oferecer a criança de classe A/B atividades escolares ligadas a área das artes via TVI utilizando como pano de fundo a obra "História em Quadrões" de Souza (2001). A partir da identificação do problema pode-se então 
extrair a seguinte pergunta: quem é o público alvo? e, qual a mecânica do projeto (ver p.64)? 0 público alvo se divide entre:

- Professores

- $\quad$ Alunos (crianças)

- Telespectador usual

A mecânica do projeto envolve Interfaces somadas a aplicativos. Estes aplicativos sugeridos são (Fig. 71):

- Quiz: perguntas e respostas ligadas ao contexto do desenho animado.

- Produtos: produtos ligados ao desenho animado.

- Textos + Infográficos: textos e ilustrações ligadas ao assunto do desenho animado.

- Atividade (teletarefa): Sugestão de tarefa, que a criança deverá realizar fora do meio televisivo, ligadas ao contexto do desenho animado.

Serão necessários outros meios para que exista a interatividade propriamente dita, no projeto.

Meios que irão complementar o projeto de TVI História em Quadrões (Fig. 68 e 69):

- Portal Turma da Mônica na Internet;

- Gibis da Turma da Mônica (bancas de revistas);

- Desenhos animados Turma da Mônica na TV;

- Filmes da Turma da Mônica no cinema;

- Lojinha de produtos da Turma da Mônica. 


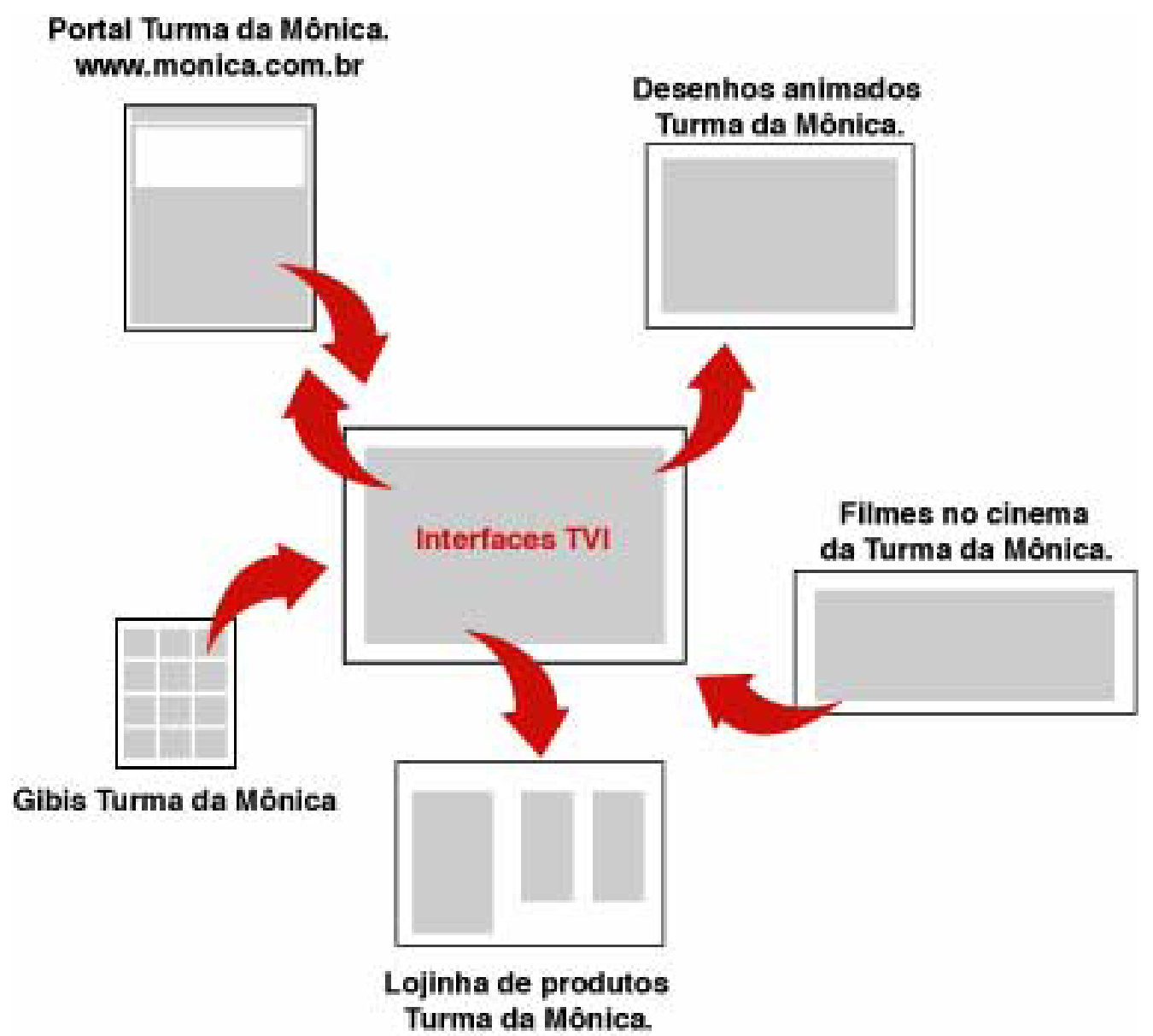

Fig 65. Esquema que identifica como os vários meios irão convergir para que a interatividade aconteça no projeto.

As setas vermelhas do diagrama acima indicam o fluxo de dados entre os meios que vamos abordar no projeto. O portal deverá tanto fornecer dados como recebê-los da Interface de TVI. Os desenhos animados, filmes de cinema, lojinha e Gibis participam apenas recebendo ou fornecendo dados. Na interface de TVI estes dados irão convergir para que se faça a interação propriamente dita.

Na interface de TVI a criança poderá não apenas assistir aos desenhos animados baseados nas histórias da "História em Quadrões", ou seja, historinhas da Turma da Mônica baseadas em quadros de pintores famosos, mas também interagir com estas histórias de modo a criar a sua própria historinha. Os desenhos animados inicialmente serão criados pelos Estúdios de Mauricio de Sousa, ao ganhar corpo, os Estúdios apenas terão que realizar a produção dos desenhos pois as idéias das histórias serão enviadas pelas crianças através do portal Turma da Mônica na Internet. Além disso, a interface vai propiciar às crianças que não se satisfizerem apenas assistindo aos desenhos, participação ao poderem se aprofudar mais na história do quadro e assim aprenderem mais sobre a vida e obra do pintor desejado. Vai também expôr os produtos 
educativos vendidos na lojinha, informando preço e um telefone para a compra e entrega via correio. O portal Turma da Mônica na Internet deverá conter uma seção dedicada ao projeto História em Quadrões, onde as crianças deverão inserir suas curiosidades relacionadas a obras de arte de artistas famosos. Esta seria uma fonte inesgotável de trabalhos pois, a cada dia surgem novas obras de arte. Esta participação incita a criatividade nas crianças, ao mesmo tempo em que alimenta os desenhos animados da TVI.

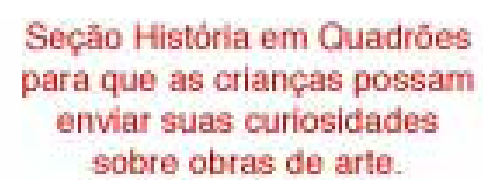

Portal Turma da Mônica. www.monica.com.br

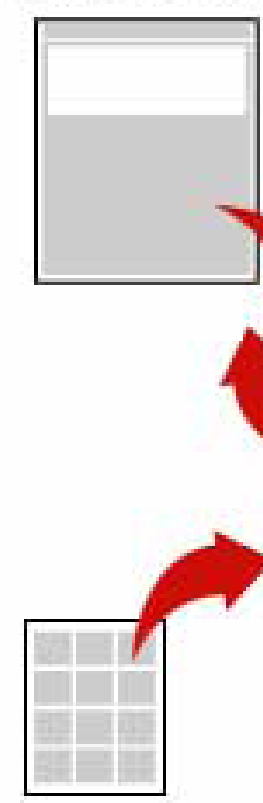

Gibis Turma da Mônica

Historinhas desenvolvidas pelos Estudios Mauricio de Souza que incitam a curiosidade em relaçăo ao mundo das artes e levam as crianças as interlaces de TVI

\author{
Desenhos produzidos \\ pelos Estudios Maurico de Sousa \\ mas criados pelas crianças \\ através do portal.
}

\title{
Desenhos animados
}

Turma da Mônica.

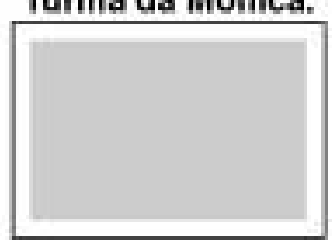

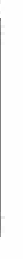
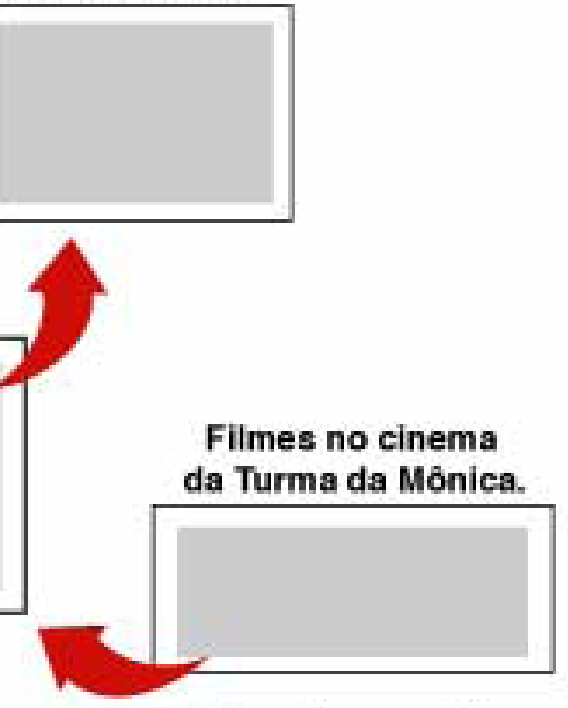

Filmes desenvolvidos pelos Estudios Mauricio de Souza que incitam a curiosidade em relaçăo ao mundo das artes e levam as crianças as interlaces de TVI

\section{Lojinha de produtos} Turma da Mónica.

Produtos desenvolvidos com o intuito de incitar nas crianças a criatividade e a curiosidade em relação ao mundo das artes.

Fig. 66. Esquema que identifica como os vários meios irão convergir para que a interatividade aconteça no projeto. 
Uma vez determinado o esquema identificando que outros meios irão convergir para que a interatividade aconteça, chega-se ao momento de refletir sobre como as interfaces do projeto História em Quadrões somadas aos aplicativos sugeridos vão se apresentar na tela da TV e propõe-se um pacote básico de aplicativos (Quiz, Produtos, Textos+Infográficos e Teletarefa) , cada um conta com:

- Tela inicial onde o usuário se identifica,

- Tela contendo a sinopse do programa que apresenta vida e obra do artista que este contém,

- Tela contendo o menu com os aplicativos,

- Tela para cada aplicativo,

- Tela de "ajuda".

Mesmo o desenvolvimento técnico do projeto em TVI não sendo o objetivo desta pesquisa, torna-se importante, nesta fase, sugerir o esquema de funcionamento do aplicativo apenas para nortear o trabalho. A figura abaixo (Fig. 70) ilustra o esquema, onde o aplicativo sugerido busca no repositório a interface correspondente ao desenho animado exibido e a joga na tela da TV.

Sugestão de esquema de funcionamento técnico:

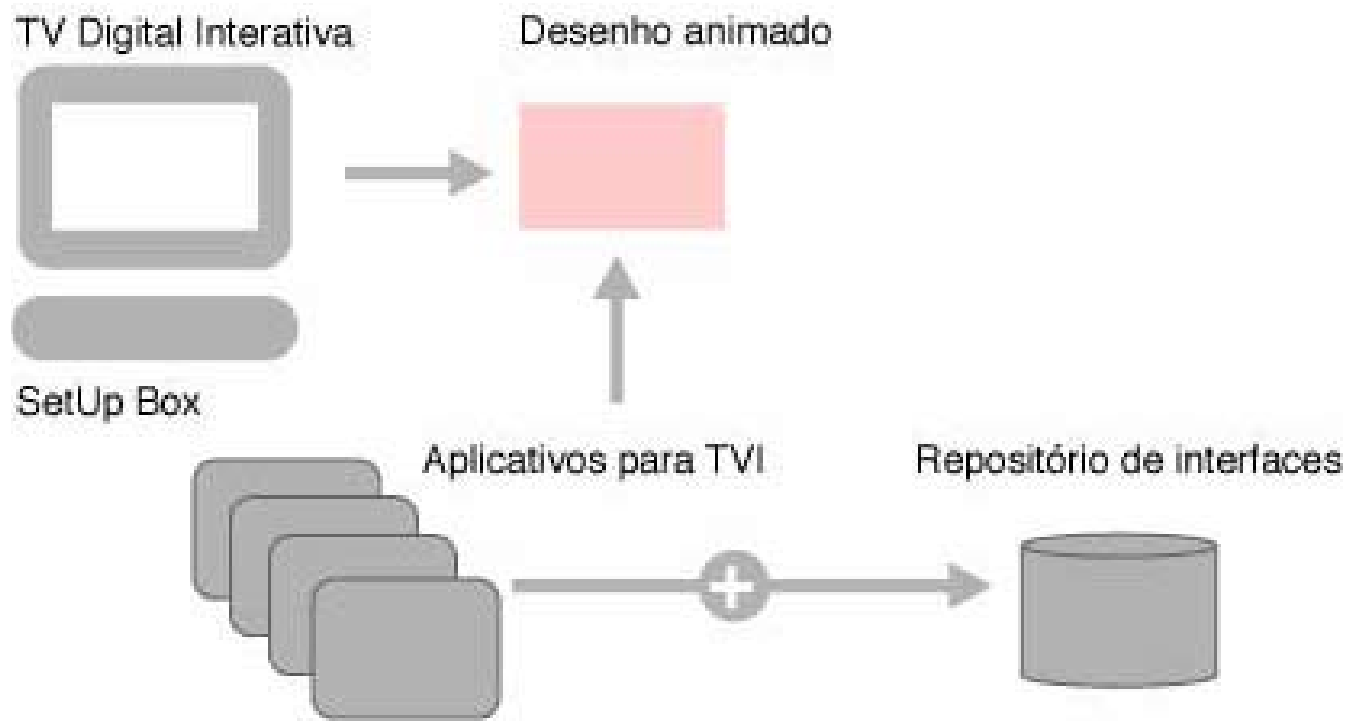

Fig. 67. Diagrama que sugere a estratégia do projeto.

O primeiro desenho sugere o mapa de distribuição da informação que vai ser exposta ao usuário. A partir deste estudo de mapa, vai-se estruturar toda a arquitetura de informação 
que tem como principal objetivo nortear o trabalho do designer e da sua equipe no sentido da distribuição de informações. No decorrer da reflexão sobre as interfaces do projeto chegou-se às seguintes considerações: cada interface gráfica vai diferenciar-se por cor, tamanho de fonte e tipologia. Vai-se customizar a nomenclatura dos aplicativos para o público alvo. Ex.: Produtos -> "Lojinha"; Quiz -> "Desafio"; Infográficos -> "Veja mais"; Atividades -> "Mão na massa".

Sugestão de mapa de informação:

\section{DESENHO ANIMADO}

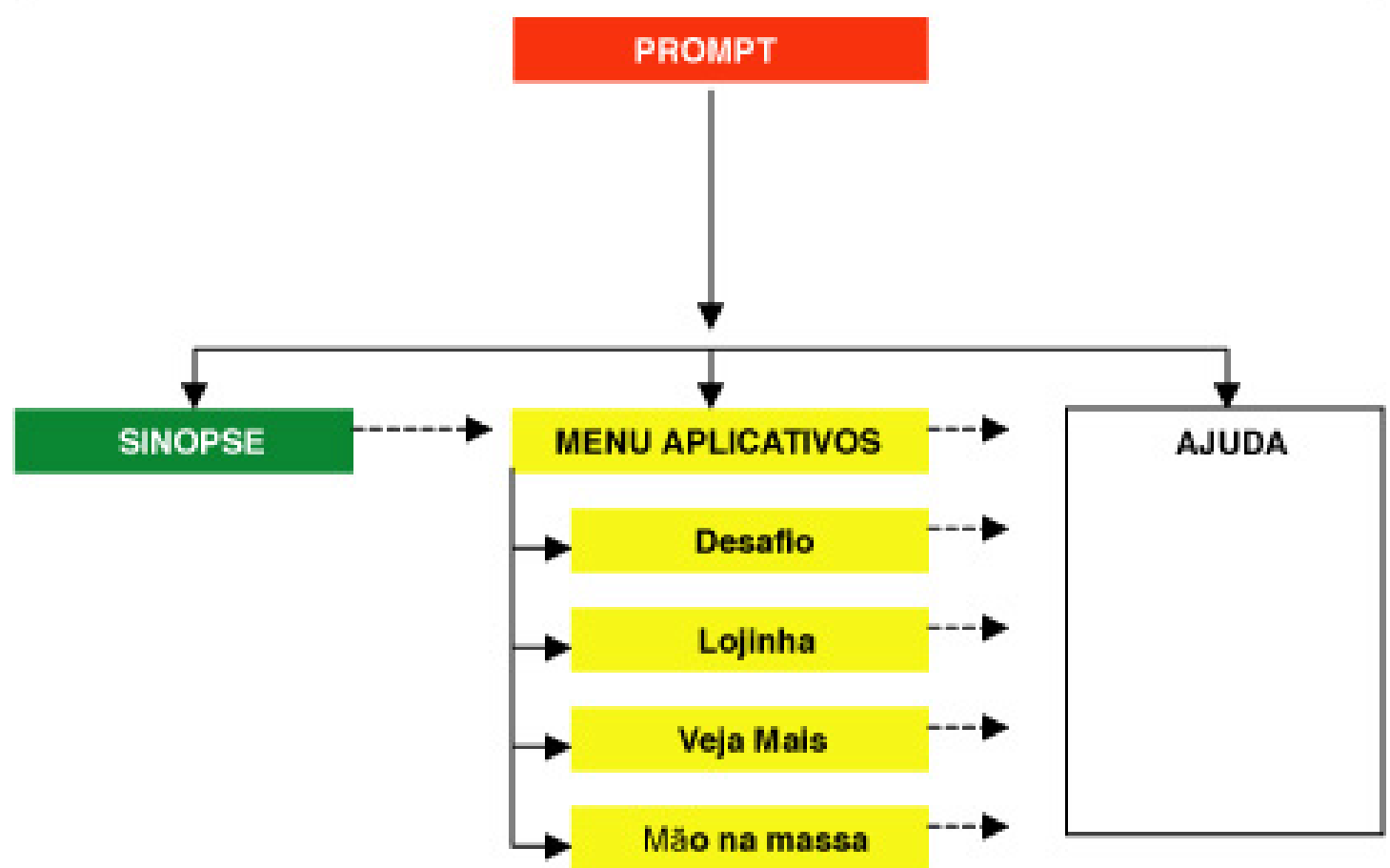

Fig. 68. Diagrama que sugere o mapa de informações. 


\section{METODOLOGIA PARA CRIAÇÃO DE INTERFACES DE TVI}

Inicialmente, antes da criação da telas das interfaces, deveremos iniciar a construção do esqueleto do projeto de interfaces gráficas do "História em Quadrões" de acordo com a articulação vista anteriormente. Este esqueleto servirá como "mapa” para o designer, para que ele vá se guiando a medida em que vai criando as telas. No esqueleto são estipuladas todas as telas, uma por uma e são detalhados todos os elementos gráficos que ela deve conter, assim como o papel que cada um deles deve cumprir frente a participação do usuário.

Esqueleto de navegação total do projeto:
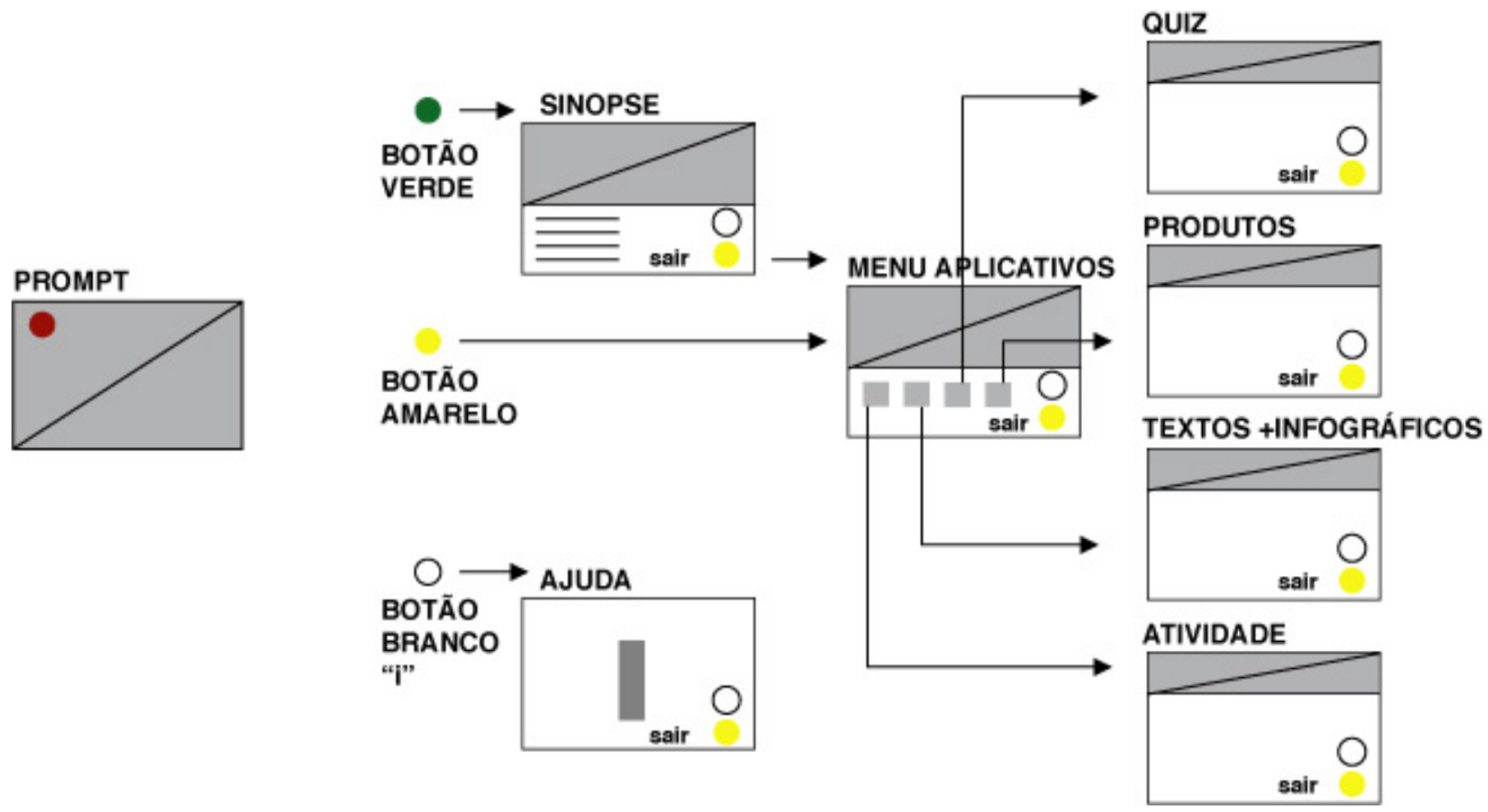

Fig. 69. Diagrama que sugere o esqueleto de navegação total do projeto. 
Esqueleto de telas de navegação para o projeto História em Quadrões.

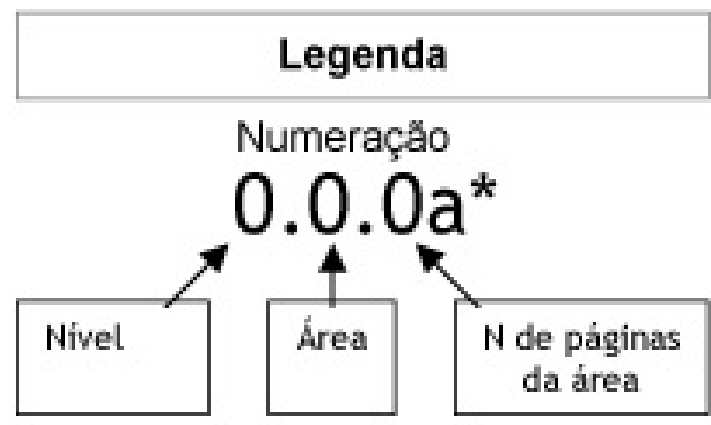

"Letras são sempre usadas para indicar que, apesar de mudança de páginas, não houve aprofundamento em niveis.

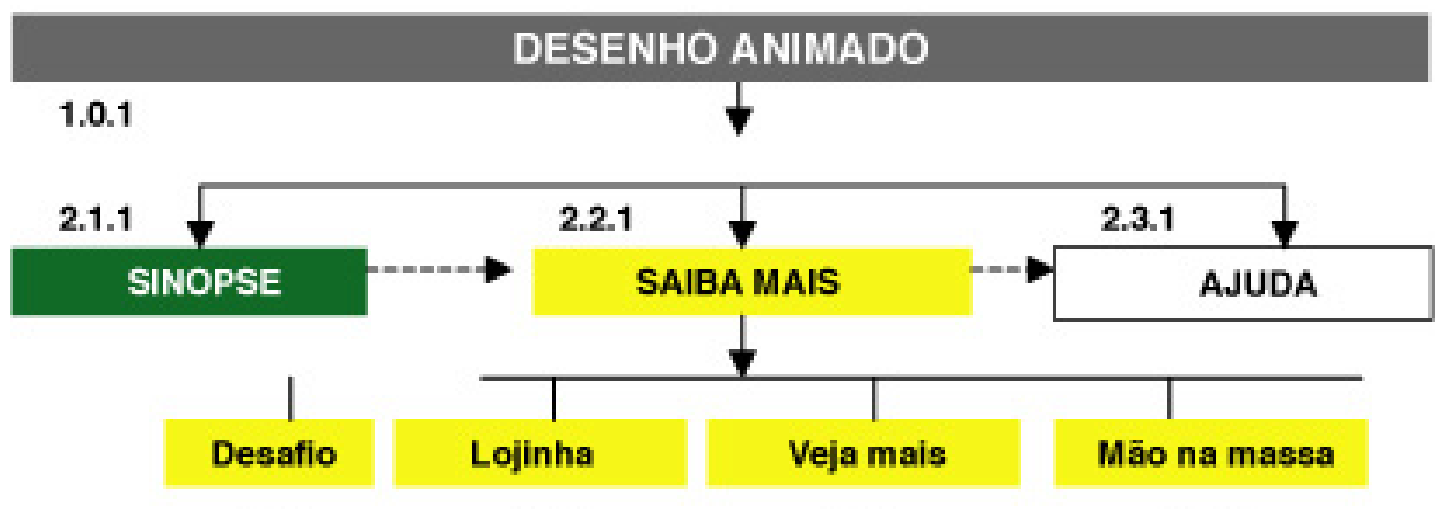

3.2.1

3.2.1

3.2.1

3.2.1 
Áreas de melhor aproveitamento da tela da TV no que condiz aos textos e imagens. Action safe area $^{32}$ é uma grande área da tela da TV onde as imagens em movimento serão melhor visualizadas. Title safe area ${ }^{33}$ é uma área menor da tela da TV onde o texto será visível, ou melhor, será preservado em termos de leitura.

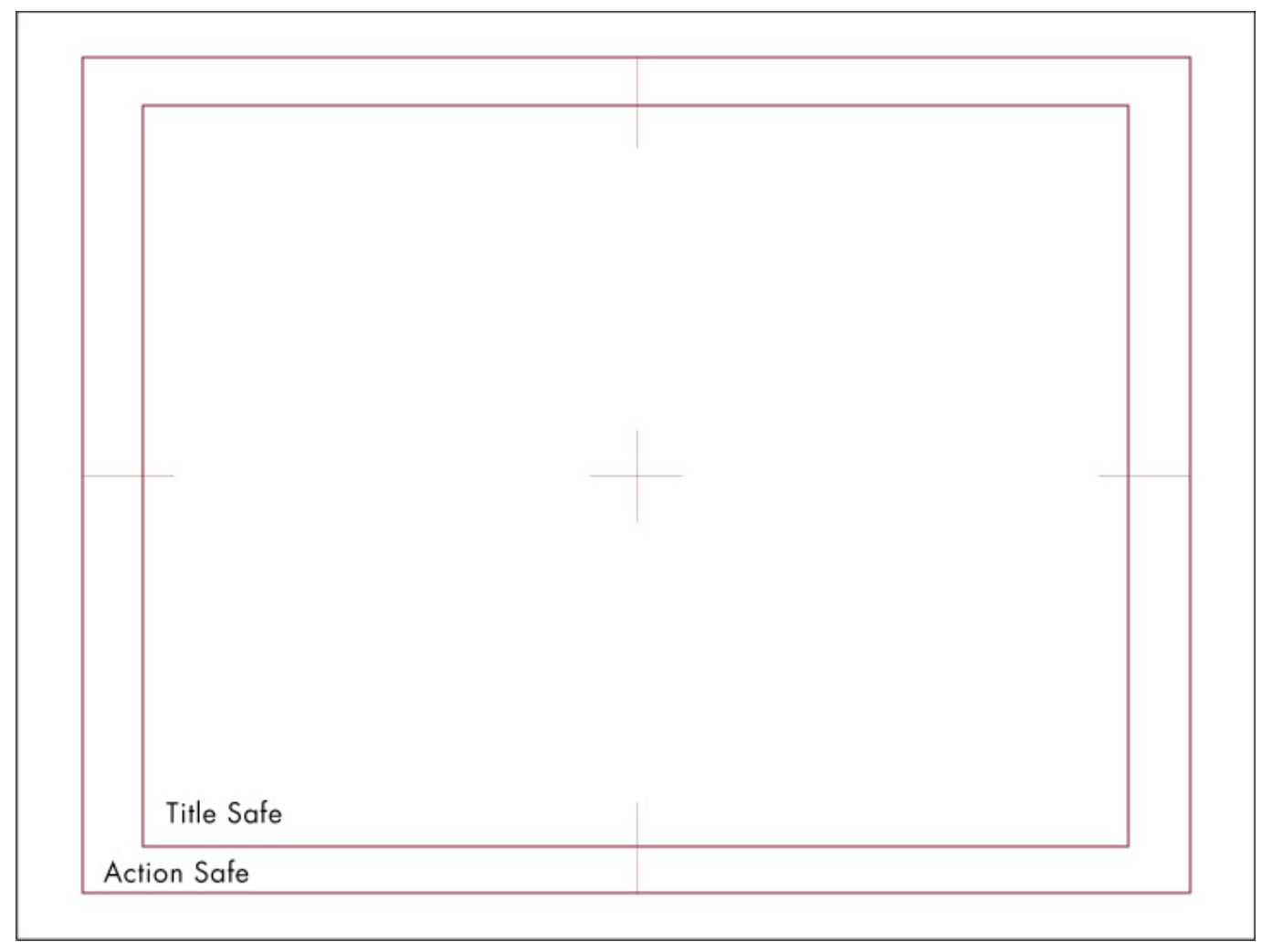

\section{Legenda}

ICONES

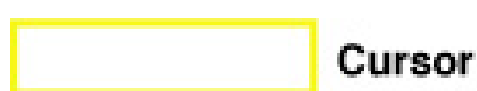

\section{BOTÕES DO CONTROLE REMOTO}

Ajuda

Voltar

Traz a interatividade

Sinopse

Saiba mais

\section{OK}

OBS::

O grau de transparência das camadas será definido nos testes.

32 Área onde as imagens em movimento serão preservadas. Não correm risco de serem cortadas na hora da produção final das telas e da transposição das mesmas para a plataforma de TVI.

33 Área onde os textos serão preservados. Não correm risco de serem cortados na hora da produção final das telas e da transposição das mesmas para a plataforma de TVI. 
Esqueleto de telas de navegação para o projeto História em Quadrões.

\subsubsection{Tela PROMPT:}

\section{PROMPT}

1 Ao escolher o programa de TV, de 5 em 5 segundo o prompt que indica conteúdo interativo aparecerá.

2 Ao pressionar o botāo vermelho, inicialmente o usuário verá a tela de mensagem aguarde, $e$, em alguns segundo, a tela sinopse aparecerá.

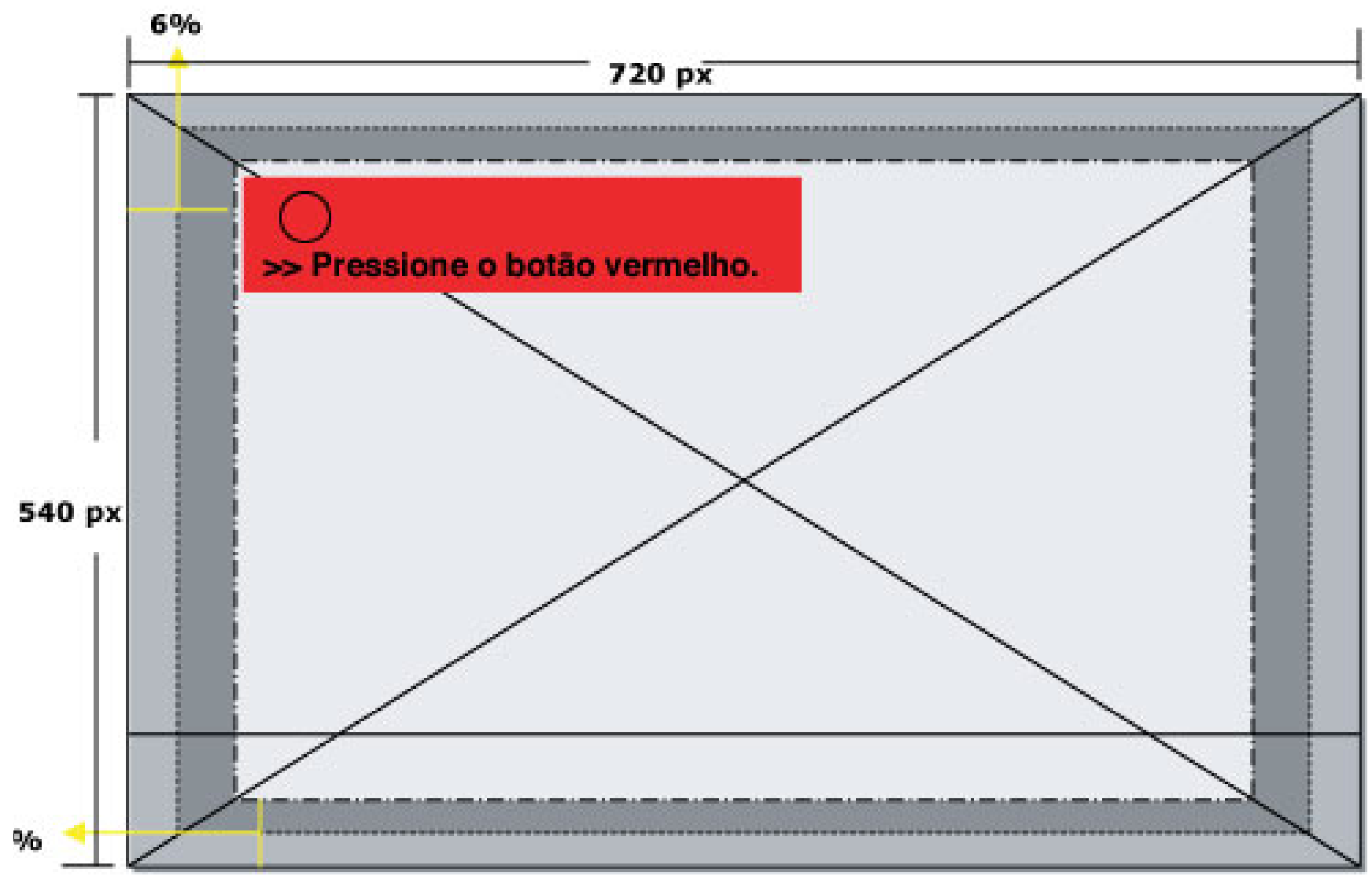


Esqueleto de telas de navegação para o projeto História em Quadrões.

1.0.1 Tela MENSAGEM:

MENSAGEM DE

CARREGAMENTO DOS

APLICATIVOS.

1 Após esta mensagem aparecerá a tela de sinopse disponivel no momento do programa.

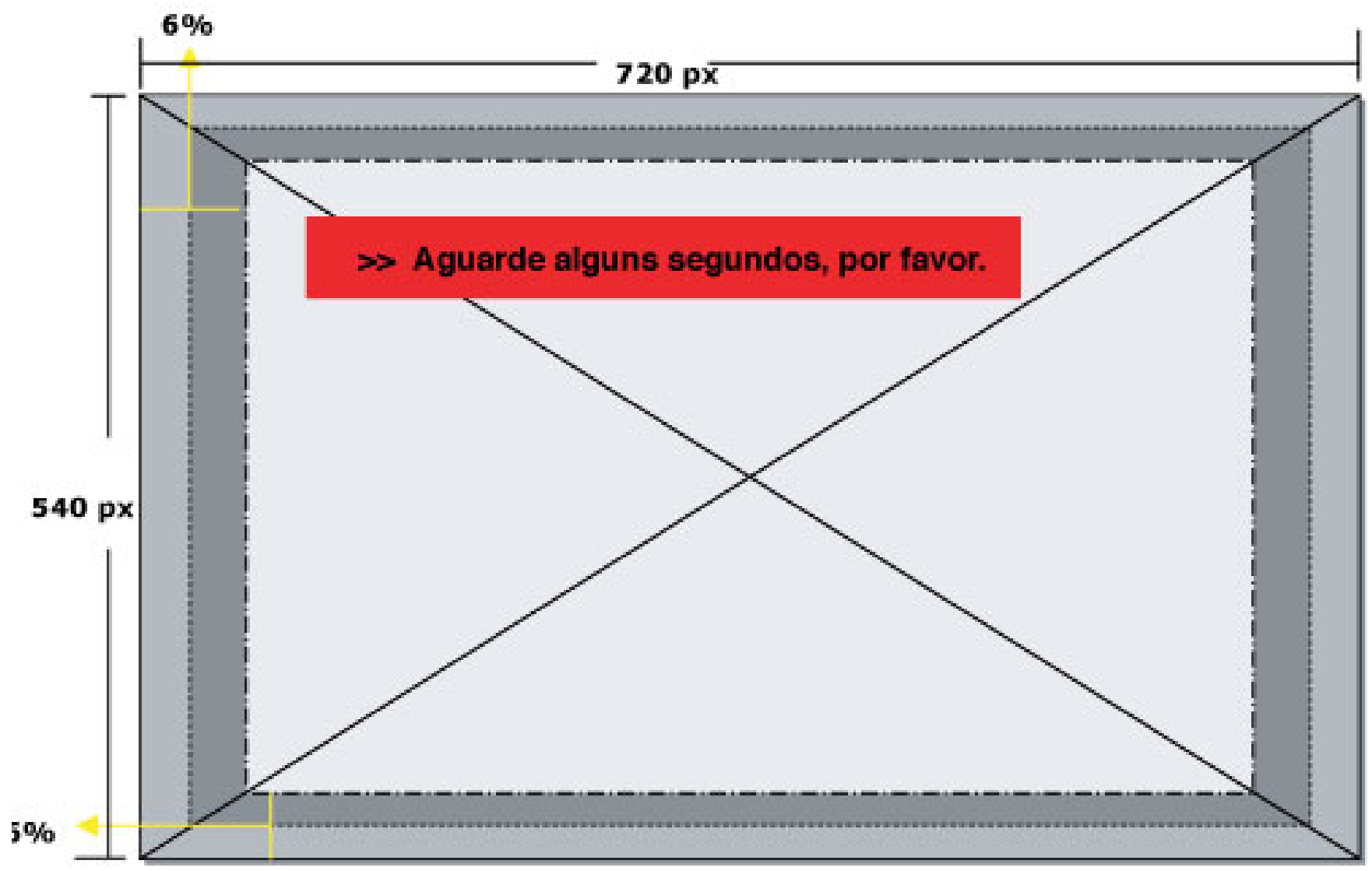


Esqueleto de telas de navegação para o projeto História em Quadrões.

\title{
2.1.1 Tela SINOPSE:
}

\section{SINOPSE}

\begin{abstract}
1 Ao escolher o programa o usuário verá a tela sinopse na camada superior e o programa de TV continuará passando embaixo.
\end{abstract}

20 usuário poderá pressionar: Azul para voltar ao prompt, branco para a tela de ajuda e amarelo para consultar o conteúdo educacional que o programa contém (Saiba mais).

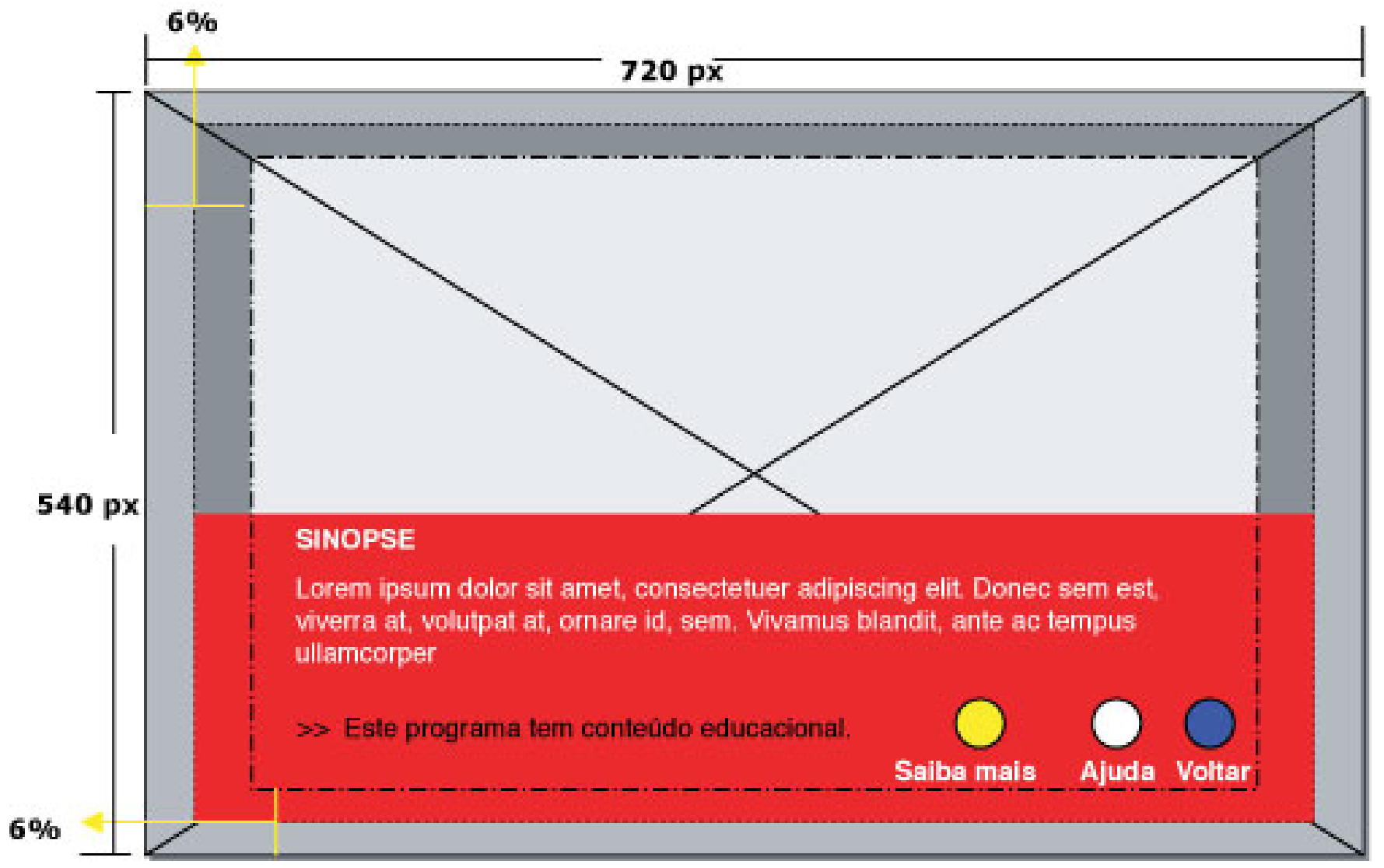


Esqueleto de telas de navegação para o projeto História em Quadrões.

\subsubsection{Tela SAIBA MAIS:}

\section{SAIBA MAIS}

1 Ao pressionar o botão amarelo do controle remoto o usuário poderá acessar o conteúdo educacional que o programa contém.

2 Ao pressionar o verde: ele voltará para a camada da sinopse.

Ao pressionar o branco: ele acessará a tela de ajuda.

Ao pressionar o azul: ele sairá da camada. Ficará apenas o programa com o prompt.

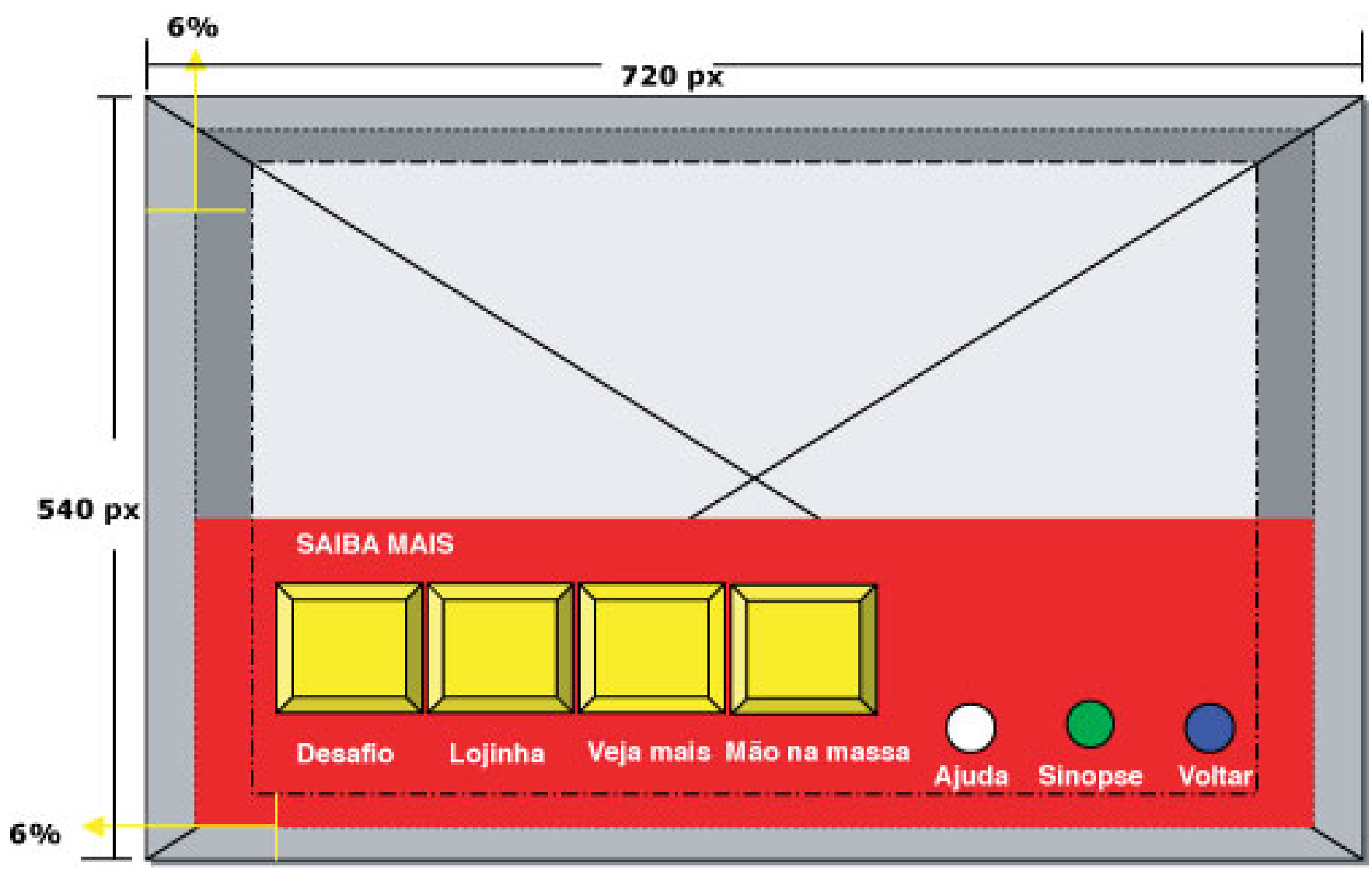


Esqueleto de telas de navegação para o projeto História em Quadrões.

\subsubsection{Tela DESAFIO:}

\section{DESAFIO}

1 Ao pressionar o botāo vermelho do controle remoto na hora que aparece o prompt na tela da TV o usuário poderá acessar o conteúdo educacional que o programa contém.

Se este conteúdo for o desafio.

2 Ele poderá pressionar: verde para resposta 1 , amarelo para resposta 2, azul para resposta 3 , ou a tecla sair do controle remoto para sair do conteúdo educacional.

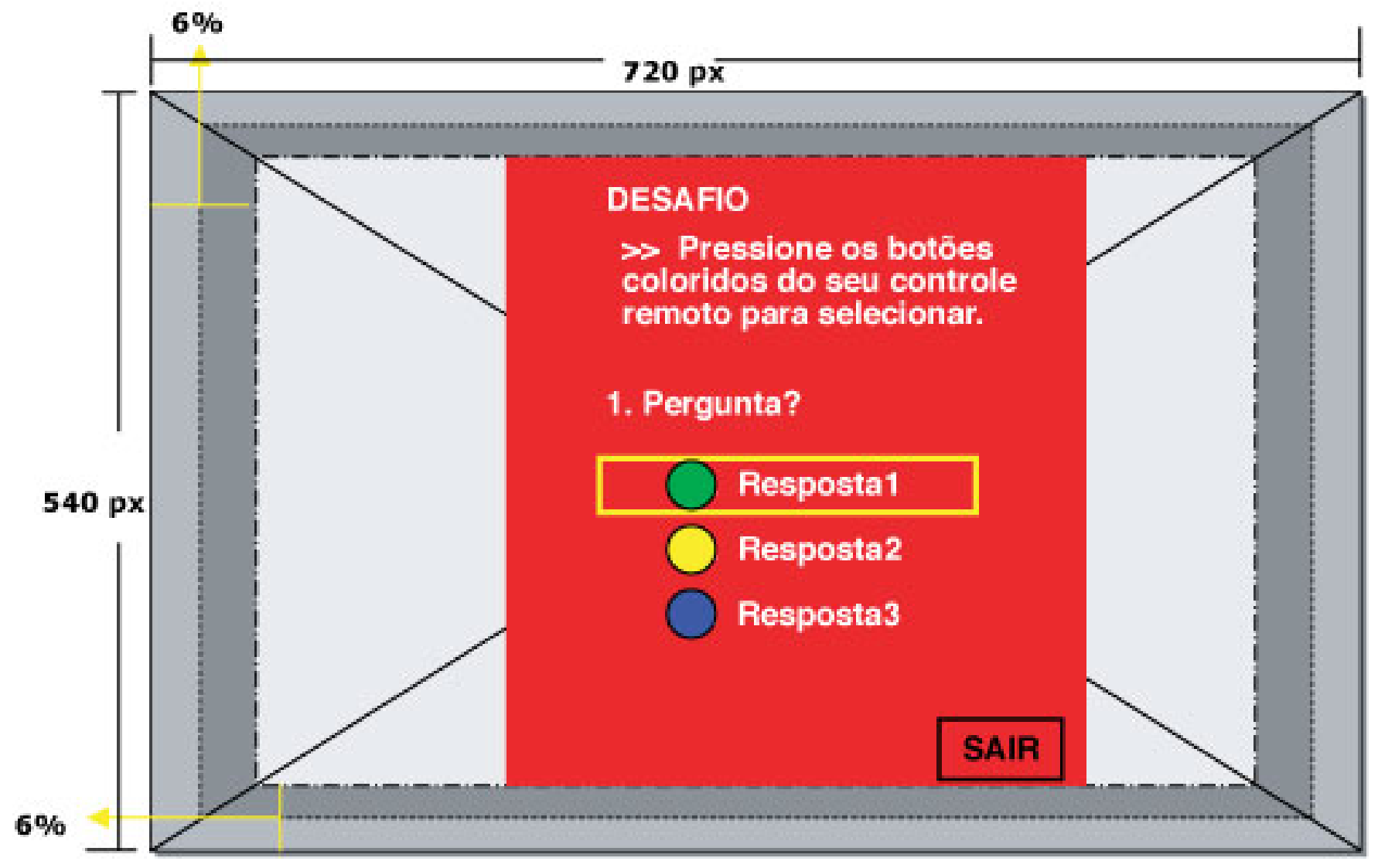


Esqueleto de telas de navegação para o projeto História em Quadrões.

3.2.1 Tela DESAFIO> RESPOSTA CERTA:

DESAFIO > RESPOSTA CERTA

1 Ao pressionar os botöes coloridos do controle remoto pra obter a resposta: Aparecerá a confirmação da resposta correta e um comentário sobre ela.

2 Ao pressionar a tecla sair do controle remoto o usuário poderá sair do desafio. Ao pressionar a tecla OK ele irá para próxima pergunta.

OBS: Por se tratar de um protótipo, só estará exemplificada uma pergunta.

Portanto, após a resposta certa a próxima tela será o final do desafio.

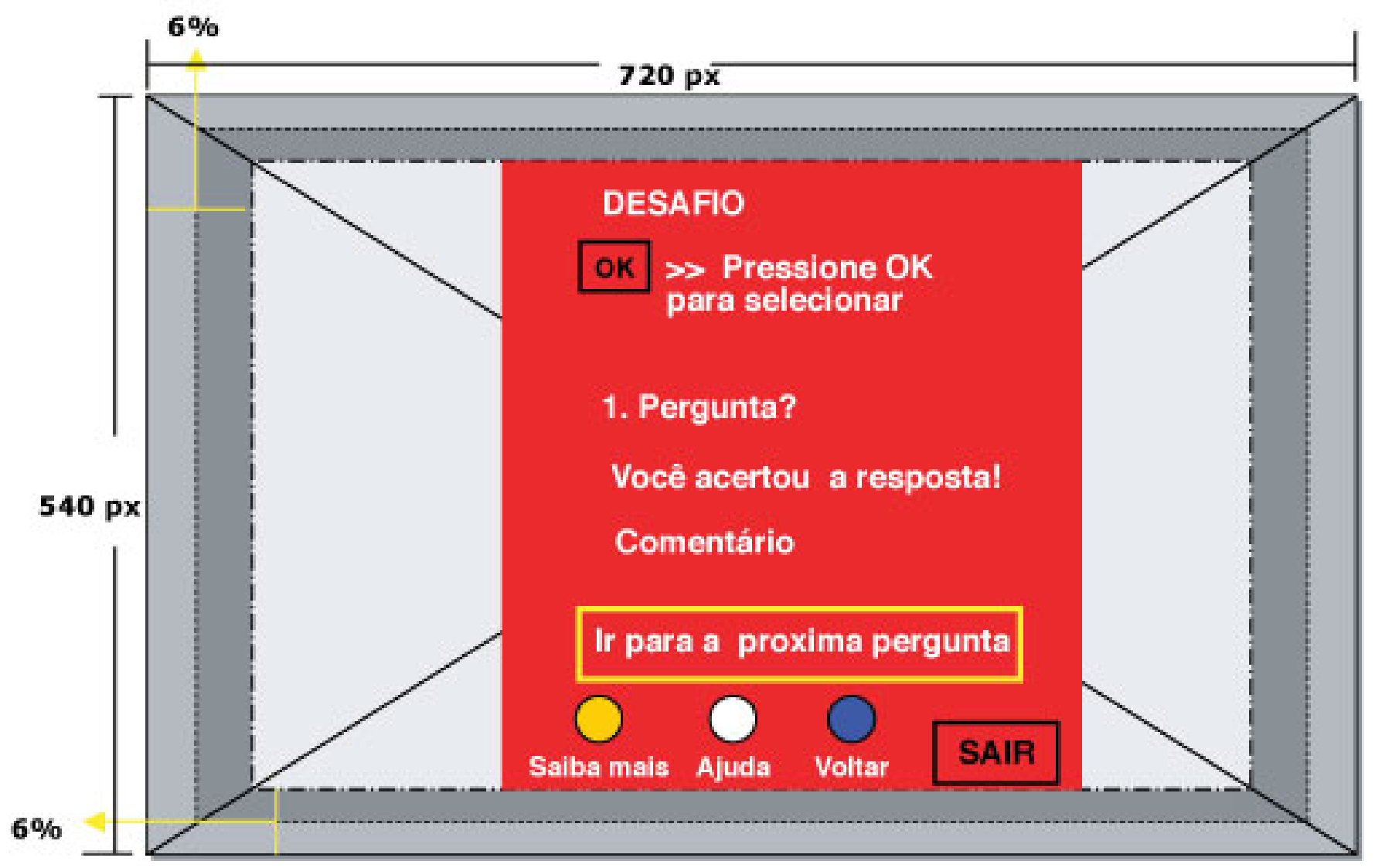


Esqueleto de telas de navegação para o projeto História em Quadrões.

\subsubsection{Tela DESAFIO> RESPOSTA ERRADA:}

\section{DESAFIO>RESPOSTA ERRADA}

1 Ao pressionar os botöes coloridos pra obter a resposta certa:

O usuário erra a resposta, aparecerá a mensagem "Tente novamente".

2 Ao pressionar a tecla sair do controle remoto ele poderá sair do desafio. Ao pressionar a tecla azul ele irá para a próxima pergunta.

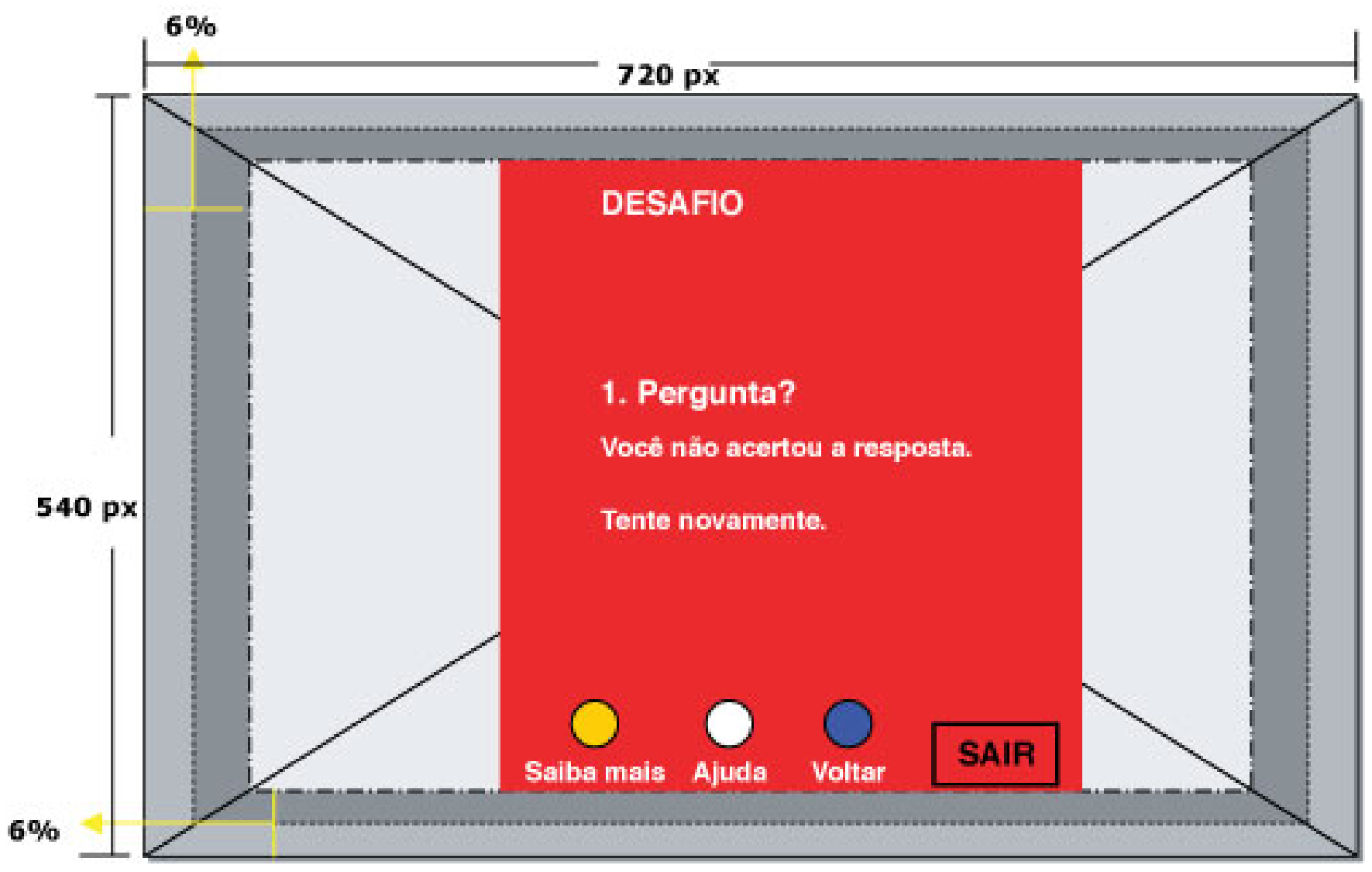


Esqueleto de telas de navegação para o projeto História em Quadrões.

\subsubsection{Tela DESAFIO> FINAL:}

\section{DESAFIO > FINAL}

10 final do desafio será sinalizado quando aparecer a quantidade de acertos e erros do usuário.

\section{Ao pressionar a tecla sair do} controle remoto o usuário poderá sair do desafio.

2 Ao pressionar o amarelo ele voltará para a camada saiba mais, o branco irá para a tela de ajuda e o azul sairá da camada. Ficará apenas o programa com o prompt. Ao pressionar a tecla sair do controle remoto o usuário voltará para a tela prompt.

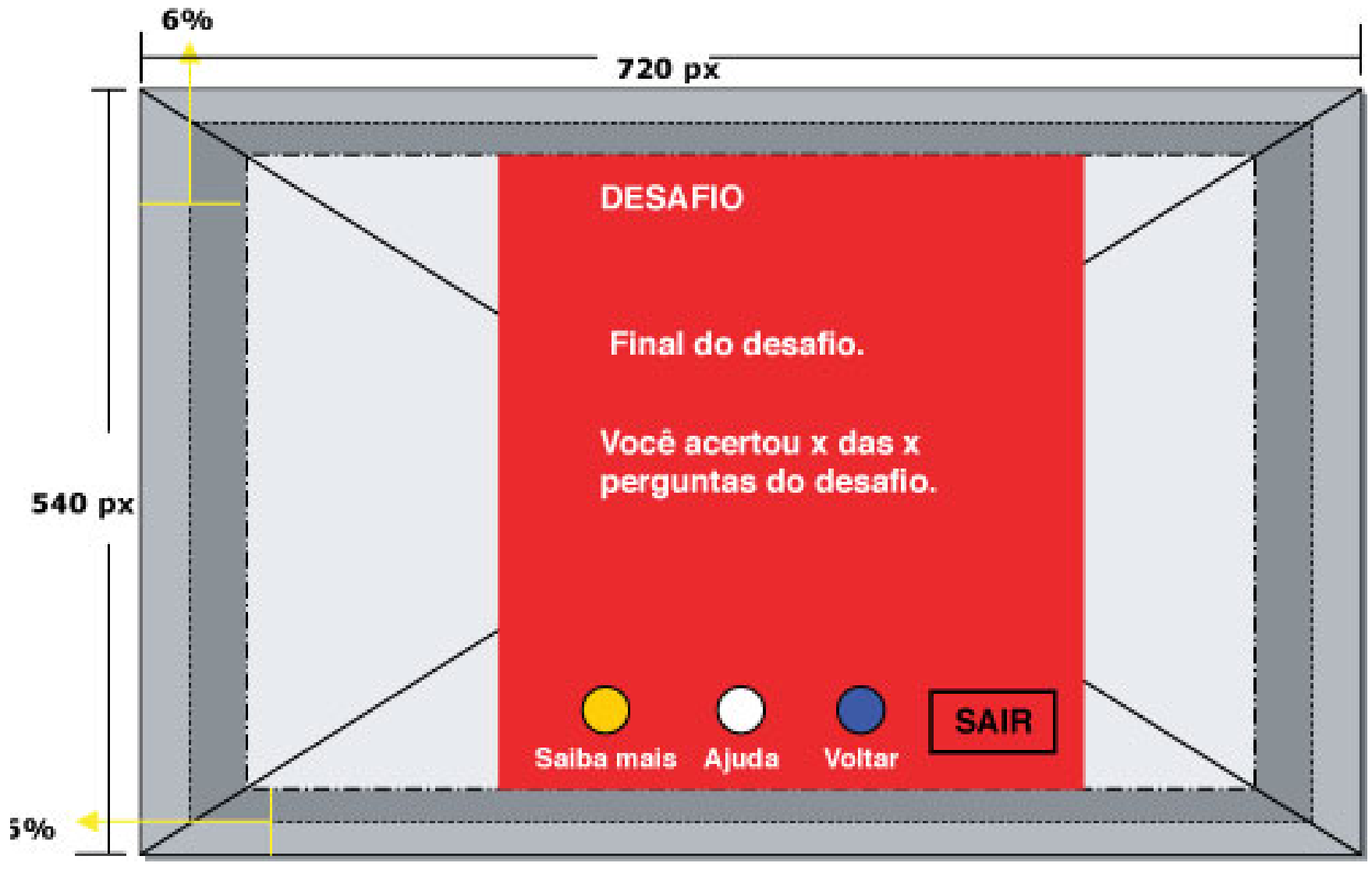


Esqueleto de telas de navegação para o projeto História em Quadrões.

\subsubsection{Tela LOJINHA:}

\section{LOJINHA}

1 Ao pressionar o botäo vermelho do controle remoto na hora que aparece o prompt na tela o usuário poderá ver o conteúdo educacional que o programa contém.

Se este conteúdo for o lojinha:

2 Ele poderá:

Usar as teclas de setas do controle para navegar nos produtos e a tecla OK para selecioná-lo.

Pressionar amarelo para saiba mais, azul para voltar para a tela saiba mais e branco (i) para ajuda. Ao pressionar a tecla sair do controle remoto o usuário voltará para a tela prompt.

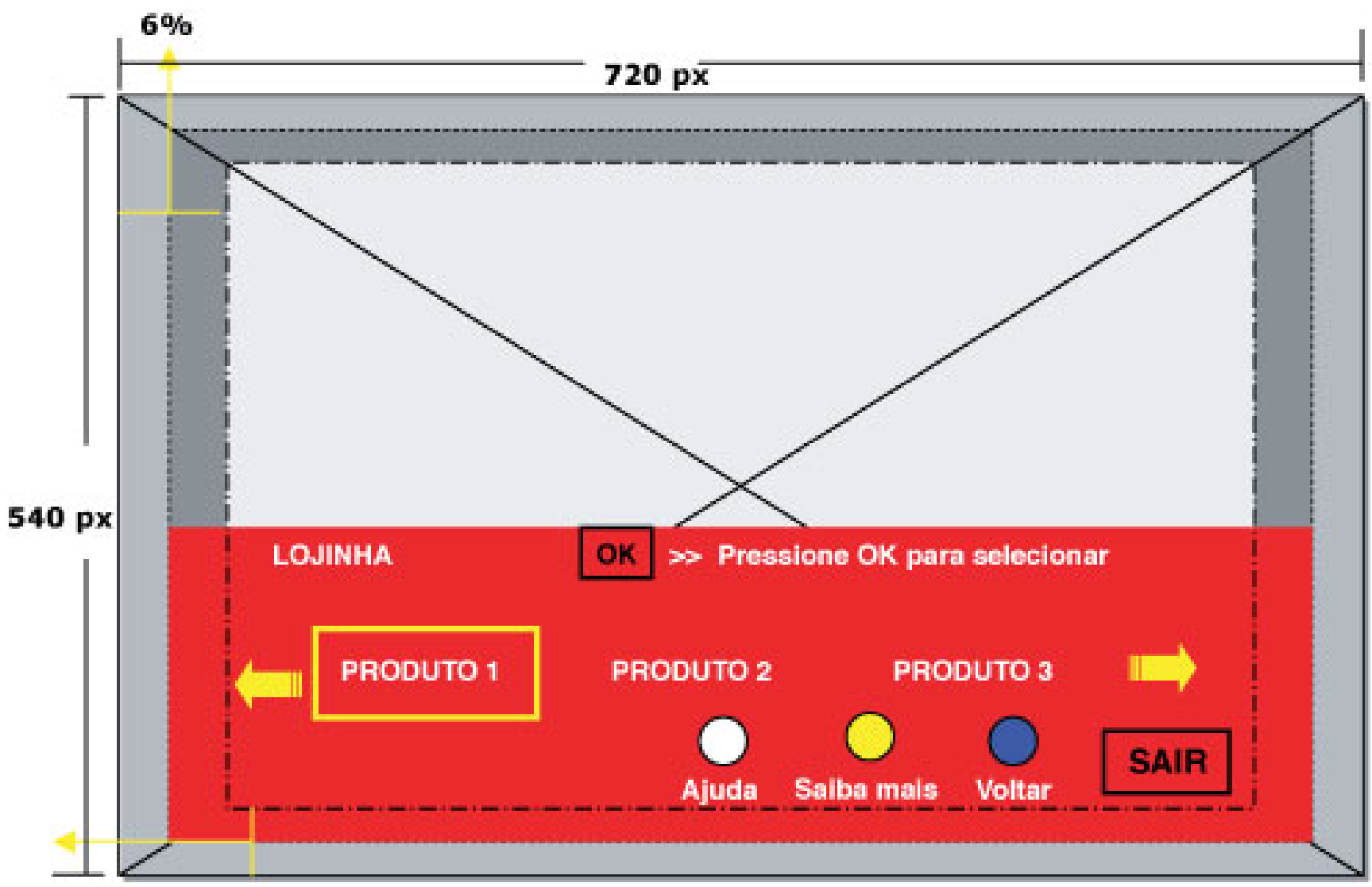


Esqueleto de telas de navegação para o projeto História em Quadrões.

3.2.1 Tela LOJINHA> PRODUTO:

\title{
LOJINHA > PRODUTOS
}

\begin{abstract}
1 Ao pressionar o OK do controle remoto e selecionar o produto desejado, este aparecerá na tela, assim como um comentário sobre ele.
\end{abstract}

20 usuário poderá:

Ao pressionar o amarelo ele voltará para a camada saiba mais, o branco irá para a tela de ajuda e o azul voltará para a tela lojinha. Ao pressionar a tecla sair do controle remoto o usuário voltará para a tela prompt.

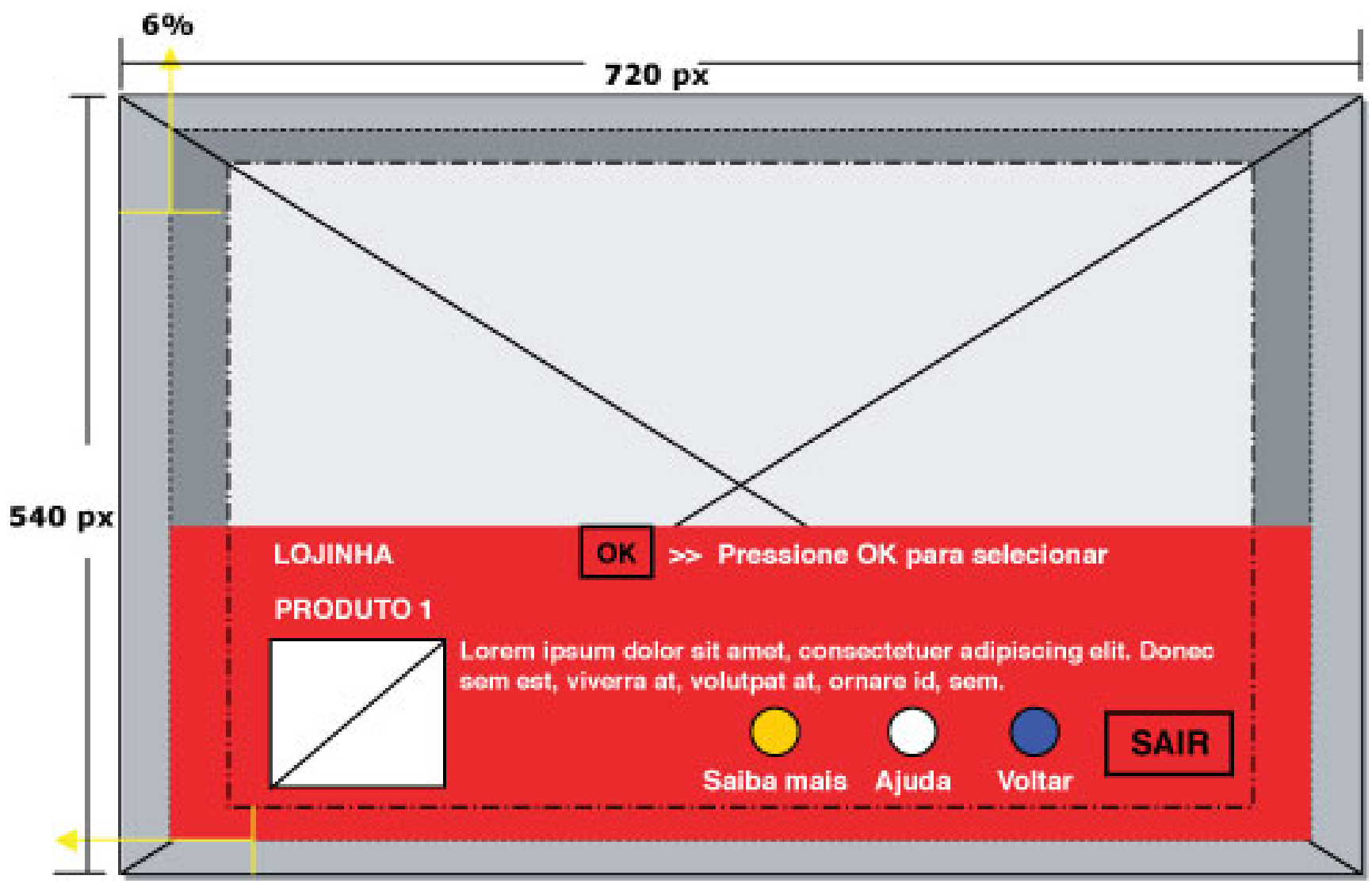


Esqueleto de telas de navegação para o projeto História em Quadrões.

\subsubsection{Tela VEJA MAIS:}

\section{VEJA MAIS}

1 Ao pressionar o botāo vermelho do controle remoto na hora que aparece o prompt na tela o usuário poderá ver o conteúdo educacional que o programa contém.

Se este conteúdo for o veja mais:

\section{Ele poderá:}

Pressionar amarelo para saiba mais, azul para voltar para a tela saiba mais e branco (i) para ajuda. Ao pressionar a tecla sair do controle remoto o usuário voltará para a tela prompt.

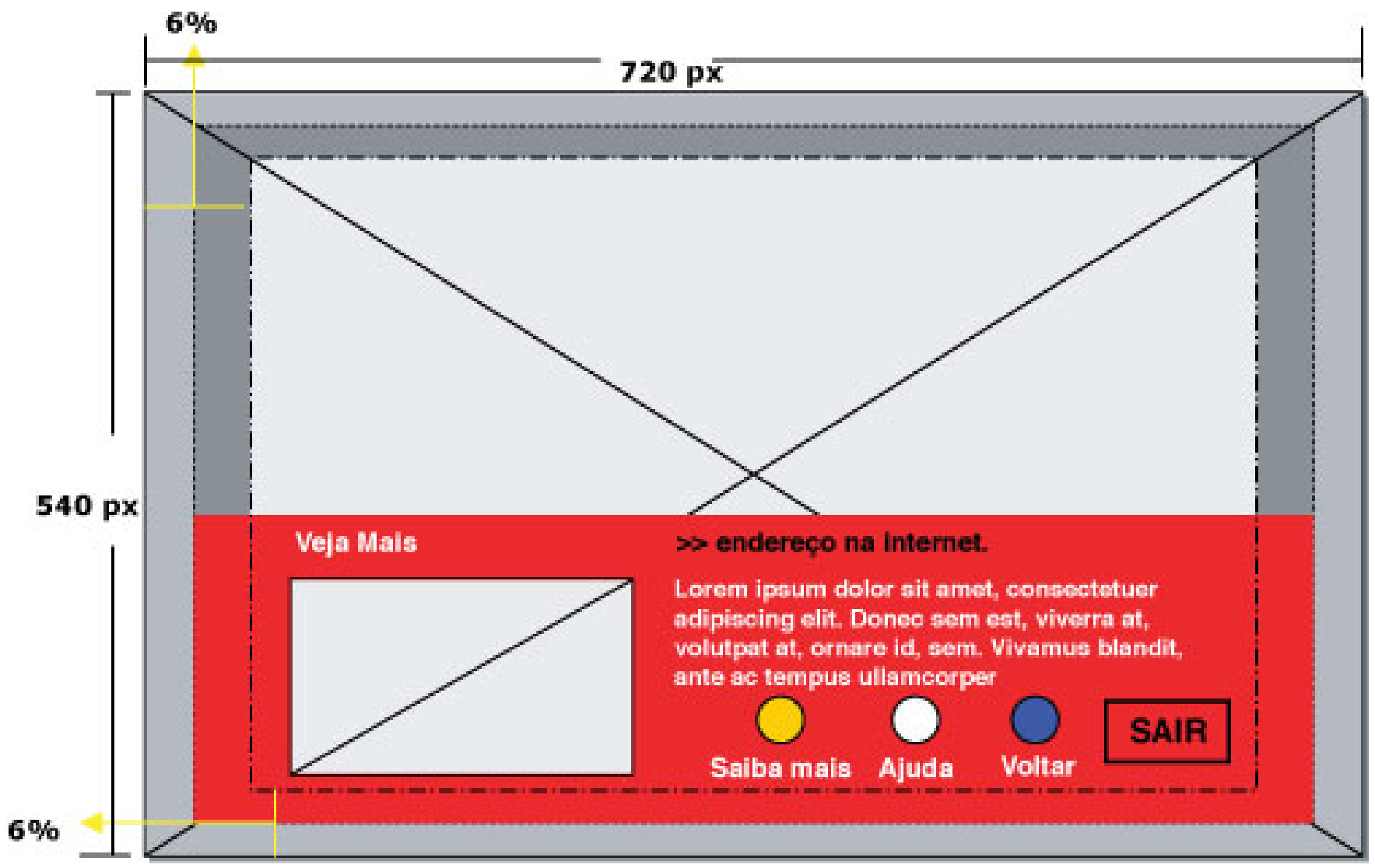


Esqueleto de telas de navegação para o projeto História em Quadrões.

\title{
3.2.1 Tela MÃO NA MASSA:
}

\section{MÃO NA MASSA}

\begin{abstract}
1 Ao pressionar o botăo vermelho do controle remoto na hora que aparece 0 prompt na tela o usuário poderá ver o conteúdo educacional que o programa contém.
\end{abstract}

Se este conteúdo for o măo na massa:

2 Ele poderá:

Pressionar amarelo para saiba mais, azul para voltar para a tela saiba mais e branco (i) para ajuda. Ao pressionar a tecla sair do controle remoto o usuário voltará para a tela prompt.

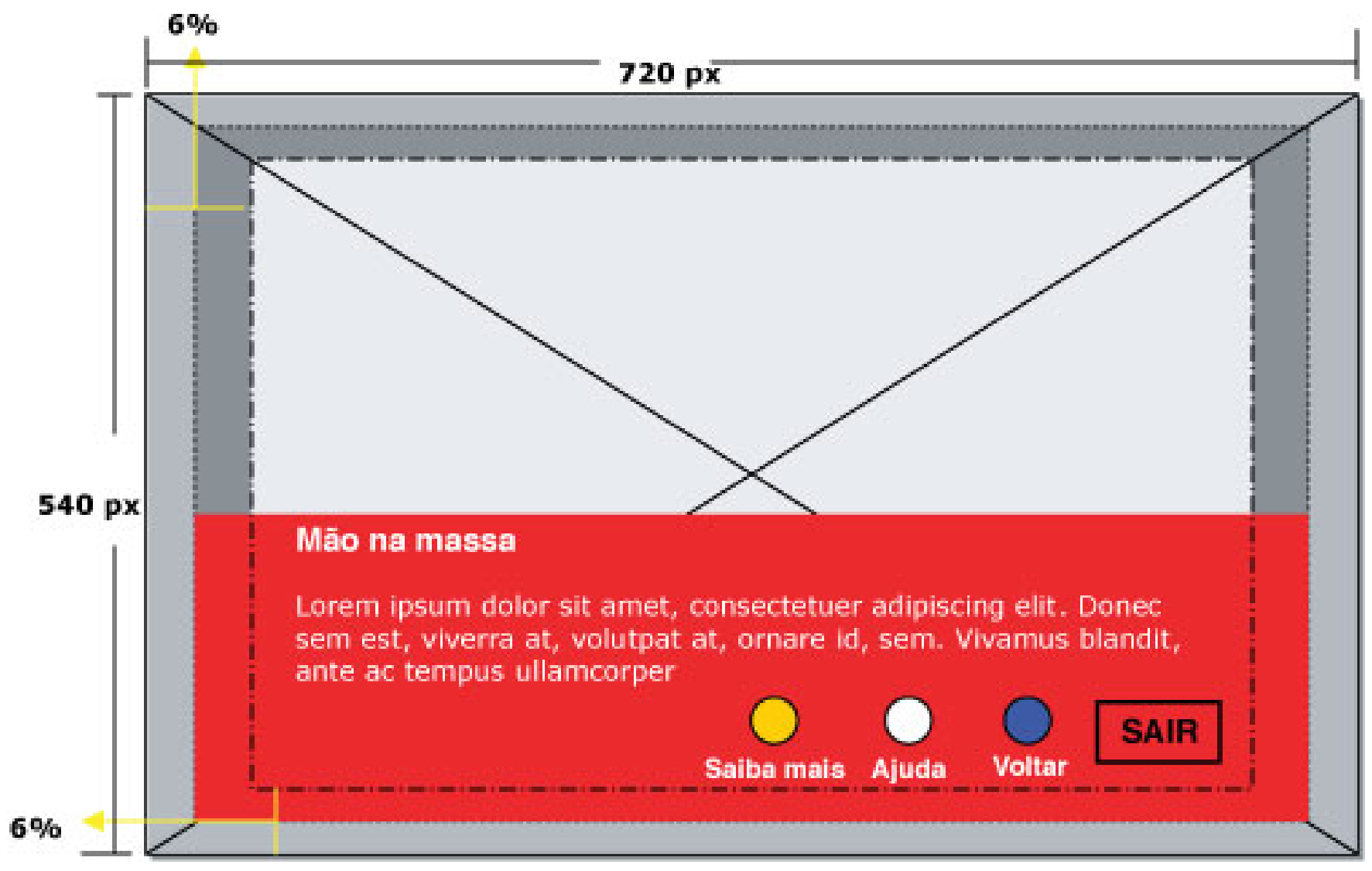


No primeiro capítulo desta pesquisa concluímos que, ao produzir as interfaces de TVI o designer se coloca o desafio de se comunicar por meio de sugestões e estratégias criativas que venham a instigar a capacidade de reflexão do telespectador. Ou seja, a busca do profissional de design é comunicar inovadoramente ao provocar a ação do telespectador.

Em seguida, foi trazido a tona o método heurístico do projeto e foram relacionados projeto e design como atividades constitutivas dos processos de desenvolvimento de interfaces de TVI. A interface e a articulação do seu projeto, como objeto central deste estudo, foram consideradas elementos essenciais no que condiz ao papel social do design das mesmas.

Apesar de todo o discurso atual sobre a convergência das mídias, conseguimos atestar no estudo de casos do capítulo III que, na maior parte das interfaces de TVI transcritas, apenas ocorre a reação do usuário, frente ao conjunto das informações. A interatividade propriamente dita foi identificada em um dos casos, mas não se relaciona ao conteúdo programático do canal de TV. Como contribuição e na tentativa de propor um projeto de interfaces de TVI interativa foi idealizada a articulação do projeto História em Quadrões que defende a convergência das mídias e apresenta a interatividade propriamente dita. 0 importante aqui foi destacar que a interatividade é premissa para gerar a ação efetiva do usuário instigando a sua capacidade de reflexão e tornando-o um integrante recriativo do processo de comunicação.

No capítulo IV, foi apresentada uma metodologia para a criação de interfaces de TVI aplicada ao projeto de TVI História em Quadrões. Vale ressaltar que esta dissertação foi desenvolvida ao longo de 3 anos, nos quais o Brasil passou pela definição do Sistema Brasileiro de TV Digital e ainda nada havia sido pesquisado sobre design de interfaces de TVI. Portanto, trata-se de um trabalho de discurso inovador, que traz ao design e sua questão social uma visão também inovadora. 
ARGAN, Giulio Carlo. História da arte como história da cidade. 5.ed. São Paulo: Ed. Martins Fontes, 2005.

BAIRD, Malcolm H. I. Eye of the World: John Logie Baird and Television (Part II). Kinema. a Journal for film and audiovisual media. Canada: Ed. Kinema, Fall 1996. Disponível em: <http://www.kinema.uwaterloo.ca/baird962.htm>. Acesso em: 01 Mar 2007.

BARNARD, Malcolm. Graphic design as communication. New York: Routledge, 2005.

BECKER, Valdecir; MONTEZ, Carlos. TV Digital Interativa. Conceitos, desafios e perspectivas para o Brasil. 2. ed. Florianópolis: Ed. Da UFSC, 2005.

BENSE, Max. Pequena estética. São Paulo: Perspectiva, 1971.

BIGAL, Solange. O desenho e o desenho industrial. 1.ed. São Paulo: Ed. Annablume, 2001.

BONSIEPE, Gui. Design as Tool for Cognitive Metabolism: From Knowledge Production to Knowledge Presentation. Itália: Politecnico di Milano, 2000.

- Design: do material ao digital. Ed. especial do LBDI para o Brasil exclusivamente. Florianópolis: IEL/LBDI,1997.

BOMFIM, Gustavo Amarante. Idéias e Formas na História do Design: uma investigação estática. Campina Grande: Universidade Federal da Paraíba - Centro de Ciências e Tecnologia - Departamento de Desenho Industrial, 1995. 
BROADBAND. iTV Video Vault. Broadband Bananas, 2006. Disponível em: <http:// broadbandbananas.com/videovault.html>. Acesso em: 18 Jun 2004.

BUCHANAN, Richard. Declaration by Design: Rethoric, Argument, and Demonstration in Design Practice. Chicago: The Univesity of Chicago Press, 1989.

CALVERA, Ana (ed.). Arte Diseño. Barcelona: Editorial Gustavo Gili, 2003.

CARDOSO, Rafael. Uma introdução à história do design. 2.ed. São Paulo: Ed. Edgard Blücher Ltda, 2004.

(org). O design brasileiro antes do design: aspectos da história gráfica, 1870-1960. São Paulo: Cosac Naify, 2005.

CAREY, John. Winky Dink To Stargazer: Five Decades of Interactive Television. In Responsibility In The New Media Landscape, CONTAMINE, C et al. (eds.), Amsterdam: European Institute For The Media, 1996.

CAREY, John. Interactive television trials and marketplace experiences. Multimedia Tools and Applications, 5, Kluwer Academic Publishers, 1997. 207-216 p.

COELHO NETTO, J. Teixeira. Semiótica, informação e comunicação. 6. ed. São Paulo: Ed. Perspectiva, 2003.

FERRARA, Lucrécia. Design em espaços. Coleção TextosDesign. São Paulo: Edições Rosari, 2002.

FIELL, Charlotte and Peter. Graphic Design for the 21th Century. Koln: Taschen GmbH, 2003. 
FRY, Tony. Televisual Designing. Design Philosophy Pappers Collection One. Ravensbourn: Austrália, p. 57-63, 2004.

FOLHA, online. Folha online, 2006. Disponível em: <http://www1.folha.uol.com.br/folha/ dinheiro/ult91u109017.shtml>. Acessado em: 08 Mai de 2007.

GRIFFITHS, Alan. Digital Television Strategies: Business Challenges and Opportunities. Great Britain: Palgrave Macmillan, 2003.

GOOGLE, Corporate Information. Google, 2007. Disponível em: <http://www.google.com/ corporate/history.html>. Acessado em: 08 de Mai de 2007.

HARRIES, Dan. The New Media Book. London: British Film Institute, 2002.

HOLLIS, Richard. Design gráfico: uma história concisa. (Tradução: Carlos Daudt) 1.ed. 2000. Coleção a. São Paulo: Martins Fontes, 2001.

INTERACTIVE. Television Alliance. ITA, 2007. Disponível em: <http://www.itvalliance.org/>. Acesso em: 29 Abr 2007.

JAKOBSON, Roman. Lingüística e comunicação. 19. ed. 2003. São Paulo: Editora Cultrix, 2003.

JOHNSON, Steven. Cultura da interface. Como o computador transforma a nossa maneira de criar e comunicar. Tradução Maria Luiza X. de A. Borges. Rio de Janeiro: Ed. Jorge Zahar, 2001, p.35. 
JOOST. Joost, 2007. Disponível em: <http://www.joost.com>. Acessado em: 08 de Mai de 2007.

LANGE, André. Histoire de la télévision. Université Libre de Bruxelles: 2002. Disponível em: http: / /histv2.free.fr/cadrehistv.htm. Acessado em 03 Mar 2007.

LÉVY, Pierre. Cibercultura. (Tradução Carlos Irineu da Costa) 2. ed. 2000. Coleção TRANS. São Paulo: editora 34, 1999.

LIVINGSTON, Alan and Isabella. The Thames \& Hudson Dictionary of Graphic Design and Designers. London: Thames \& Hudson Ltd, 2003.

LÖBACH, Bernd. Design Industrial. Bases para a configuração dos produtos industriais. (Tradução Freddy Van Camp) São Paulo: Ed. Edard Blücher Ltda, 2001.

LU, Karyn Y. Interaction design principles for interactive television. 2005. Tese (Mestrado) Master of Science in Information Design and Technology. Georgia Institute of Technology, 2005.

MACHADO, Arlindo. A televisão levada a sério. 3.ed. São Paulo: Ed. Senac São Paulo, 2003.

MALDONADO, Tomás. Design Industrial. (Tradução José Francisco Espadeiro Martins). Lisboa: Edições 70, 1999.

MANOVICH, Lev. The Language of New Media. Massachusetts: The MIT Press, 2001. 
MANZINI, Ezio. Products in a Period of Transition. In. BALCIOGLU, Tevfik. The role of product design in post-industrial society. Kent: Kent Institute of Art and Design, p. 43 - 58, 1998.

A matéria da invenção. Lisboa: Centro Português de Design, 1993.

MARGOLIN, Victor. O design e a situação mundial. Design Issues. v12, n2, p. 40-49, 1996.

MATTOS, Sérgio. A Televisão no Brasil: 50 anos de história (1950-2000). Salvador: Editora PAS- Edições lanamá, 2000.

MIRANDA, José Bragança de. 0 design como problema. Interact. Revista online arte. Cultura e tecnologia, n.10, p.1-20, fev. 2004. Disponível em http://www.interact.com. pt/interact10/ensaio/ensaio3.html. Acesso em fev. 2006.

MOLES, Abraham. Teoria da Informação e Percepção Estética. 2.ed. Brasília, DF: Editora Universidade de Brasília, 1978.

MORAES, De Dijon. Análise do design brasileiro: entre mímese e mestiçagem. São Paulo: Ed. Blucher, 2006.

MUNARI, Bruno. Das coisas nascem coisas. São Paulo: Ed. Martins Fontes, 2002. Artista y designer. (Tradução: Joaquin Espinosa Carbonell). Valencia: Editor Fernando Torres, 1974.

MUSEUM OF BROADCAST COMMUNICATION, The. The encyclopedia of television, 2005. Disponível em: <http://www.museum.tv/archives/etv/>. Acesso em 20 Fev 2007. 
OSTROWER, Fayga. Criatividade e processos de criação. Petrópolis: Ed. Vozes, 1987.

PACEY, Philip. 'Anyone Designing Anything? ' Non-professional Designers and the History of Design. Journal of Design History 5 (1992):3, 217-225.

PAPANEK, Victor. The best designer in the world. Tools 3(1987):3,10-12.

.Design or the real world. Human ecology and social change. 2. ed. London: Thames and Hudson, 2004.

PEÑALVA, Sergio Horácio; RODIO, Stella Maris. Diseño y conocimiento. Buenos Aires: Kliczkowski, 2002.

PEREIRA, Luis Bravo. A Televisão, um pouco de história... 1999, Disponível em: <http:// si.porto.ucp.pt/internal/mestrado/mest99/Teoria_media/tv/TEXTOS\%20FINAIS/1_ A\%20Invencao.htm> Acessado em: 03 de Mar 2007.

PLAZA, Julio. Arte e interatividade: autor-obra-recepção. ARS Revista do departamento de artes plásticas ECA-USP. São Paulo, v.2, n.20, p. 9-29, 2003.

PLAZA, Júlio; TAVARES, Monica. Processos Criativos com os Meios Eletrônicos: Poéticas Digitais. São Paulo: Editora Hucitec, 1998.

PIGNATARI, Décio. Informação linguagem comunicação. São Paulo: Ed. Ateliê editorial, 2002.

SAMPAIO, Mario Ferraz. História do Rádio e da Televisão no Brasil e no Mundo (memórias de um pioneiro). Rio de Janeiro: Achiamé Editora, 1984. 
SANTAELLA, Lúcia. Matrizes da linguagem e pensamento - sonora visual verbal. São Paulo: Ed. Iluminuras, 2001.

Culturas e artes do pós-humano: da cultura das mídias a cibercultura. 2.ed. São Paulo: Ed. Paulus, 2004.

SANTAELLA, Lúcia e NÖTH, Winfried. Imagem - Cognição, semiótica, mídia. São Paulo: Ed. Iluminuras, 1997.

SANTOS, Laymert Garcia dos. Politizar as novas tecnologias. 0 impacto sócio-tecnico da informação digital e genética. São Paulo: Ed 34, 2003.

SARNOFF LIBRARY, The David. David Sarnoff Collection. New Jersey: 2001-2002. <Disponível em: http://www.davidsarnoff.org> Acessado em: 03 mar 2007.

SELLERS, Libby (org.).25/25 Celebrating 25 years of Design. London: Design Museum, 2007.

SEVERIANO, Antônio. Metodologia do trabalho cientifico. São Paulo: Cortez Editora, 2003.

SOUSA, Mauricio. História em Quadrões. Pinturas de Maureicio de Souza. São Paulo: Globo, 2001.

SOUZA, Moacir Barbosa de. Evolução tecnológica da radiodifusão. Salvador: XXV Congresso Brasileiro de Ciências da Comunicação, 2002. 
SPARKE, Penny. An Introduction to Design and Culture in the Twentieth Century. Icon Editions. New York: Harper \& Row, Publisher, 1986.

SPARKE, penny; HODGES, Felice; STONE, Anne; DENT COAD, Emma. Diseño. História en Imagenes. Tradução Juan Manuel Ibeas. Madrid: Herman Blume, 1987.

SWEDLOW, Tracy. 2000: Interactive Enhanced Television: AHistorical and Critical Perspective. The American Film Institute | Intel Corporation: 2000. Diponível em: < http://www.itvt. com/etvwhitepaper.html>. Acessado em 29 de Abr de 2007.

TAMBINI, Michael. The Look of the century. London: Dorling Kindersley Ltd, 1996.

TAVARES, Mônica. A recepção no contexto das poéticas interativas. 2000. 341 f. Tese (Doutorado em Artes) - Escola de Comunicação e Artes, Universidade de São Paulo, São Paulo, 2000.

Aspectos estruturais e ontogênicos da interatividade. 2001. Disponível em: <http://wawrwt.iar.unicamp.br/gtcompos2001/monica.html>. Acessado em 2 Jun 2003.

. Por uma tipologia da imagem interativa. 2002. Disponível em: <http:// wawrwt.iar.unicamp.br/GTcompos2002/monica.html>. Acessado em 21 Abr 2004.

TELETEXT. Teletext then and now, the teletext museum. Disponível em: <http://teletext. mb21.co.uk/>. Acessado em 17 Mar 2007.

THOMASSON, Michael. Winky Dink, the History of Interactive Television, and You. Gooddealgames.com, 2003. Disponível em: <http://www.gooddealgames.com/articles/ Winky_Dink.html>. Acesso em: 03 Mar 2007. 
VV.AA. Diseño: Teoria y Reflexion. Buenos Aires: Ed. Kliczkowski, 2002. 